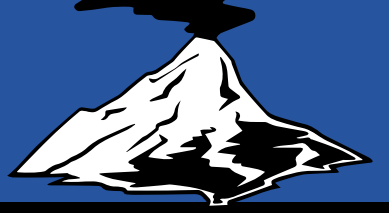

\title{
Geologic Field-Trip Guide to Mount Mazama and Crater Lake Caldera, Oregon
}

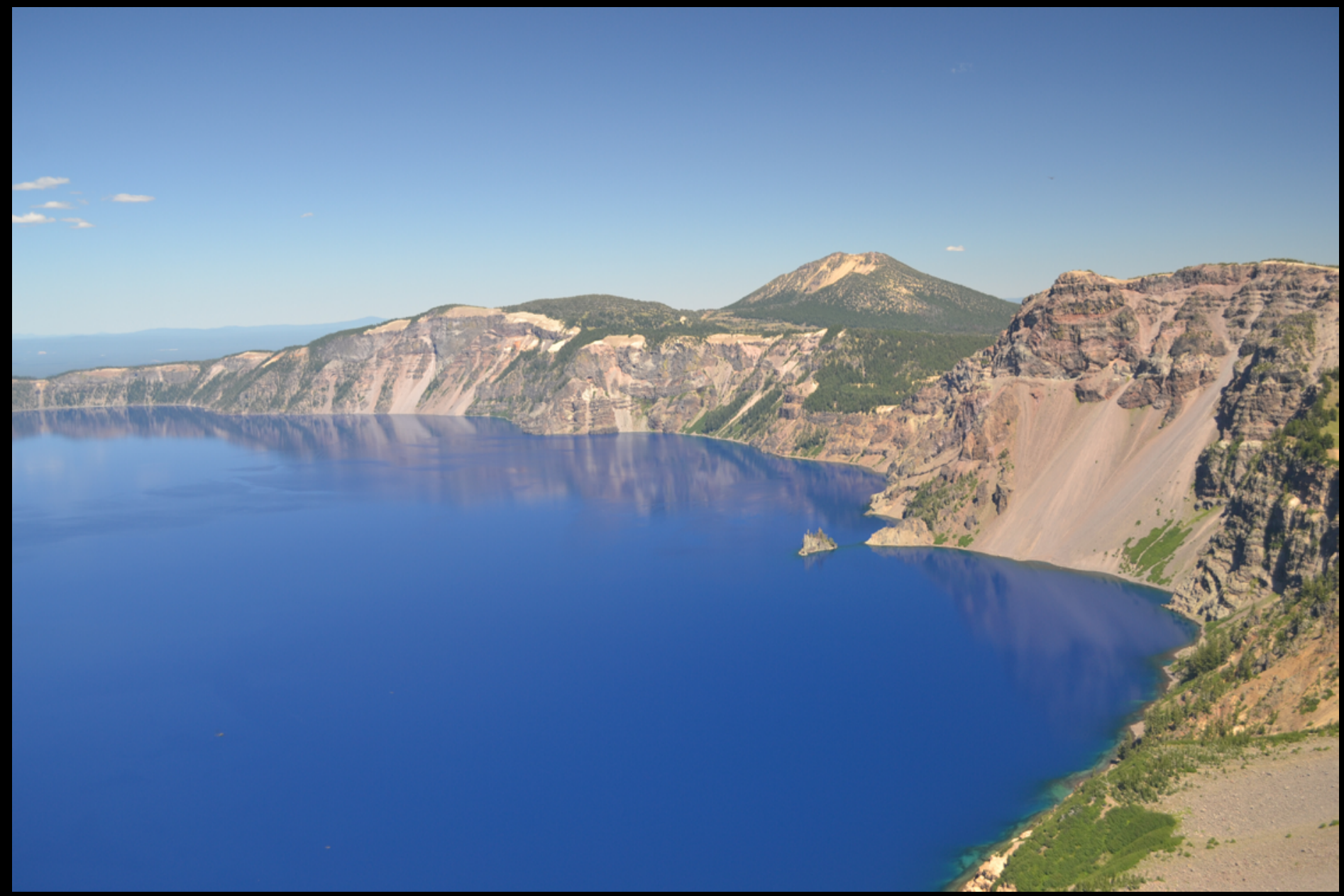

Scientific Investigations Report 2017-5022-J1 
Cover: View east-northeast from Garfield Peak on the south rim of Crater Lake caldera. Peak on skyline is 8,929 feet (2,722 meters) Mount Scott, an $\sim 420$ thousand years before present (ka) dacite stratovolcano considered to be part of Mount Mazama, the volcano that collapsed during the calderaforming eruption $\sim 7,700$ years ago. The caldera walls in this view expose Mazama lava flows and fragmental deposits from as old as $\sim 400 \mathrm{ka}$ at Phantom Cone, adjacent to tiny Phantom Ship island, to as young as $\sim 27 \mathrm{ka}$ at Redcloud Cliff, the V-shaped face at the top of the wall left of center. The beheaded glacial valley of Kerr Notch, the low point on the caldera rim, is seen between Phantom Ship and Mount Scott. (Photograph by Carly McLanahan.) 


\section{Geologic Field-Trip Guide to Mount Mazama and Crater Lake Caldera, Oregon}

By Charles R. Bacon and Heather M. Wright

Scientific Investigations Report 2017-5022-J1 


\title{
U.S. Department of the Interior \\ RYAN K. ZINKE, Secretary
}

\section{U.S. Geological Survey William H. Werkheiser, Acting Director}

\author{
U.S. Geological Survey, Reston, Virginia: 2017
}

For more information on the USGS — the Federal source for science about the Earth, its natural and living resources, natural hazards, and the environment-visit https://www.usgs.gov or call 1-888-ASK-USGS.

For an overview of USGS information products, including maps, imagery, and publications, visit https://store.usgs.gov.

Any use of trade, firm, or product names is for descriptive purposes only and does not imply endorsement by the U.S. Government.

Although this information product largely is in the public domain, it may also contain copyrighted materials as noted in the text. Permission to reproduce copyrighted items must be secured from the copyright owner.

Suggested citations:

Bacon, C.R., and Wright, H.M., 2017, Geologic field trip guide to Mount Mazama and Crater Lake Caldera, Oregon: U.S. Geological Survey Scientific Investigations Report 2017-5022-J1, 47 p., https://doi.org/10.3133/sir20175022J1.

ISSN 2328-0328 (online) 


\section{Preface}

The North American Cordillera is home to a greater diversity of volcanic provinces than any comparably sized region in the world. The interplay between changing plate-margin interactions, tectonic complexity, intra-crustal magma differentiation, and mantle melting have resulted in a wealth of volcanic landscapes. Field trips in this series visit many of these landscapes, including (1) active subduction-related arc volcanoes in the Cascade Range; (2) flood basalts of the Columbia Plateau; (3) bimodal volcanism of the Snake River Plain-Yellowstone volcanic system; (4) some of the world's largest known ignimbrites from southern Utah, central Colorado, and northern Nevada; (5) extension-related volcanism in the Rio Grande Rift and Basin and Range Province; and (6) the spectacular eastern Sierra Nevada featuring Long Valley Caldera and the iconic Bishop Tuff. Some of the field trips focus on volcanic eruptive and emplacement processes, calling attention to the fact that the western United States provides opportunities to examine a wide range of volcanological phenomena at many scales.

The 2017 Scientific Assembly of the International Association of Volcanology and Chemistry of the Earth's Interior (IAVCEI) in Portland, Oregon, marks the first time that the U.S. volcanological community has hosted this quadrennial meeting since 1989, when it was held in Santa Fe, New Mexico. The 1989 field-trip guides are still widely used by students and professionals alike. This new set of field guides is similarly a legacy collection that summarizes decades of advances in our understanding of magmatic and tectonic processes of volcanic western North America.

The field of volcanology has flourished since the 1989 IAVCEI meeting, and it has profited from detailed field investigations coupled with emerging new analytical methods. Mapping has been enhanced by plentiful major- and trace-element whole-rock and mineral data, technical advances in radiometric dating and collection of isotopic data, GPS (Global Positioning System) advances, and the availability of lidar (light detection and ranging) imagery. Spectacularly effective microbeam instruments, geodetic and geophysical data collection and processing, paleomagnetic determinations, and modeling capabilities have combined with mapping to provide new information and insights over the past 30 years. The collective works of the international community have made it possible to prepare wholly new guides to areas across the western United States. These comprehensive field guides are available, in large part, because of enormous contributions from many experienced geologists who have devoted entire careers to their field areas. Early career scientists are carrying forward and refining their foundational work with impressive results.

Our hope is that future generations of scientists as well as the general public will use these field guides as introductions to these fascinating areas and will be enticed toward further exploration and field-based research.

Michael Dungan, University of Oregon Judy Fierstein, U.S. Geological Survey Cynthia Gardner, U.S. Geological Survey Dennis Geist, National Science Foundation

Anita Grunder, Oregon State University John Wolff, Washington State University

Field-trip committee, IAVCEI 2017 


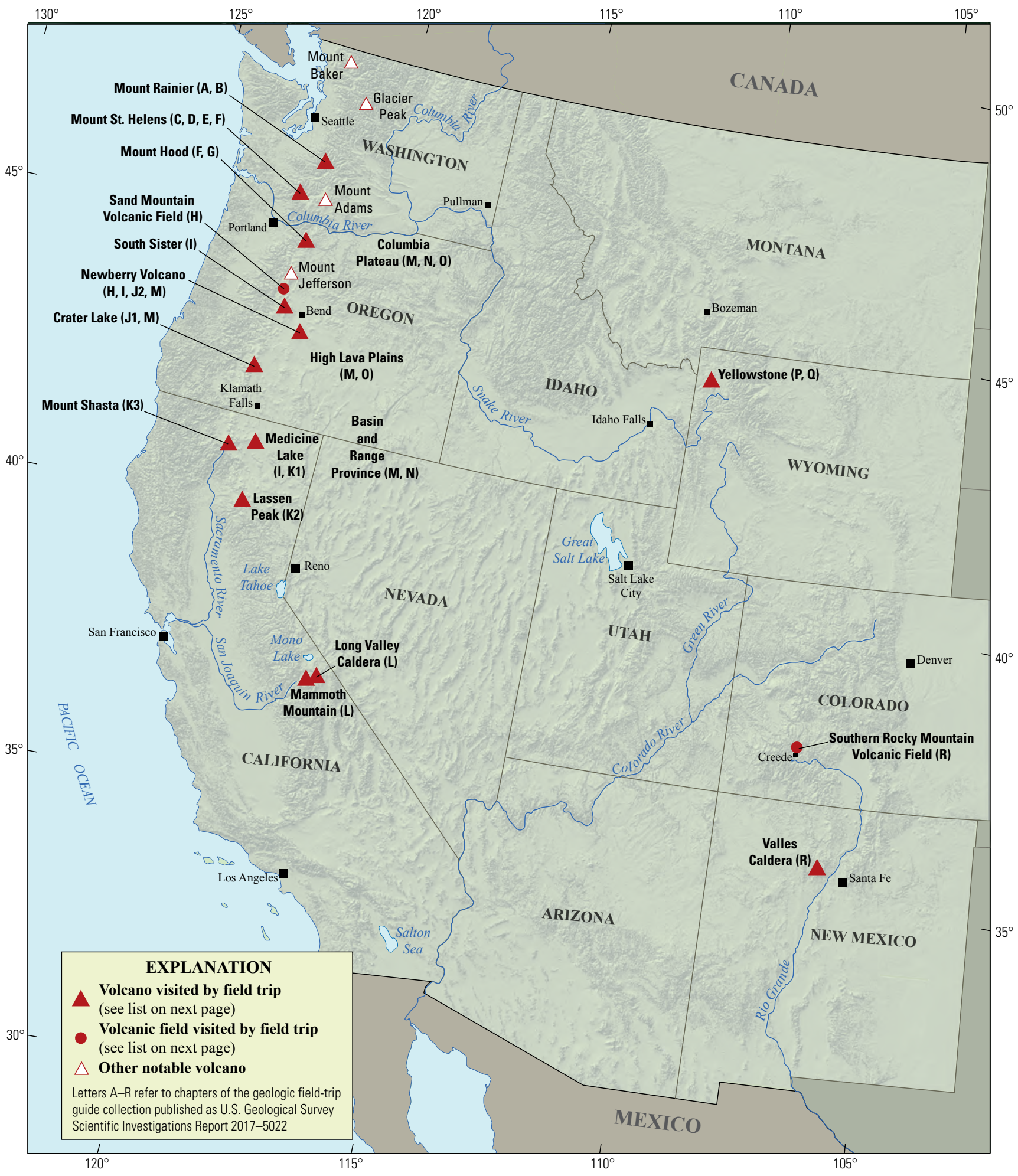

Map of the western United States showing volcanoes and volcanic fields visited by geologic field trips scheduled in conjunction with the 2017 meeting of the International Association of Volcanology and Chemistry of the Earth's Interior (IAVCEI) in Portland, Oregon, and available as chapters in U.S. Geological Survey Scientific Investigations Report 2017-5022. Shaded-relief base from U.S. Geological Survey National Elevation

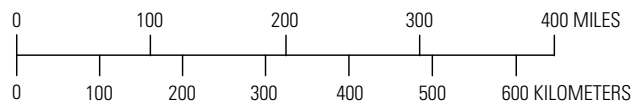
Dataset 30-meter digital elevation model data. 


\author{
Chapter \\ letter \\ Title \\ A \\ Field-Trip Guide to Volcanism and Its Interaction with Snow and Ice at Mount Rainier, \\ Washington \\ B \\ Field-Trip Guide to Subaqueous Volcaniclastic Facies in the Ancestral Cascades Arc in \\ Southern Washington State-The Ohanapecosh Formation and Wildcat Creek Beds \\ C \\ Field-Trip Guide for Exploring Pyroclastic Density Current Deposits from the May 18, 1980, \\ Eruption of Mount St. Helens, Washington \\ D Field-Trip Guide to Mount St. Helens, Washington—An Overview of the Eruptive History \\ and Petrology, Tephra Deposits, 1980 Pyroclastic Density Current Deposits, and the \\ Crater \\ $E$ \\ $\mathrm{F}$ \\ G \\ H \\ Field-Trip Guide to Mount St. Helens, Washington—Recent and Ancient Volcaniclastic \\ Processes and Deposits \\ Geologic Field-Trip Guide of Volcaniclastic Sediments from Snow- and Ice-Capped \\ Volcanoes-Mount St. Helens, Washington, and Mount Hood, Oregon \\ Field-Trip Guide to Mount Hood, Oregon, Highlighting Eruptive History and Hazards \\ Field-Trip Guide to Mafic Volcanism of the Cascade Range in Central Oregon-A \\ Volcanic, Tectonic, Hydrologic, and Geomorphic Journey \\ Field-Trip Guide to Holocene Silicic Lava Flows and Domes at Newberry Volcano, \\ Oregon, South Sister Volcano, Oregon, and Medicine Lake Volcano, California \\ Overview for Geologic Field-Trip Guides to Mount Mazama, Crater Lake Caldera, and \\ Newberry Volcano, Oregon \\ Geologic Field-Trip Guide to Mount Mazama and Crater Lake Caldera, Oregon \\ Field-Trip Guide to the Geologic Highlights of Newberry Volcano, Oregon \\ Overview for Geologic Field-Trip Guides to Volcanoes of the Cascades Arc in Northern \\ California \\ Geologic Field-Trip Guide to Medicine Lake Volcano, Northern California, Including Lava \\ Beds National Monument \\ Geologic Field-Trip Guide to the Lassen Segment of the Cascades Arc, Northern \\ California \\ Geologic Field-Trip Guide to Mount Shasta Volcano, Northern California \\ Geologic Field-Trip Guide to Long Valley Caldera, California \\ Field-Trip Guide to a Volcanic Transect of the Pacific Northwest \\ Field-Trip Guide to the Vents, Dikes, Stratigraphy, and Structure of the Columbia River \\ Basalt Group, Eastern Oregon and Southeastern Washington \\ Field-Trip Guide to Flood Basalts, Associated Rhyolites, and Diverse Post-Plume \\ Volcanism in Eastern Oregon \\ Field-Trip Guide to the Volcanic and Hydrothermal Landscape of Yellowstone Plateau, \\ Montana and Wyoming \\ Field-Trip Guide to the Petrology of Quaternary Volcanism on the Yellowstone Plateau, \\ Idaho and Wyoming \\ Field-Trip Guide to Continental Arc to Rift Volcanism of the Southern Rocky \\ Mountains-Southern Rocky Mountain, Taos Plateau, and Jemez Volcanic Fields of \\ Southern Colorado and Northern New Mexico
}




\section{Contributing Authors}

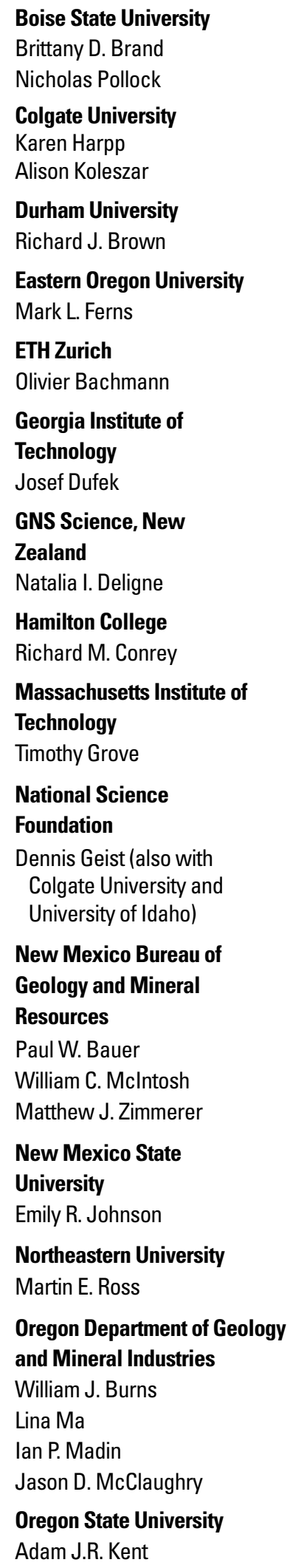

\author{
Portland State University \\ Jonathan H. Fink (also with \\ University of British Columbia) \\ Martin J. Streck \\ Ashley R. Streig
}

San Diego State University
Victor E Camp

Smithsonian Institution

Lee Siebert

Universidad Nacional

Autónoma de San Luis Potosi

Damiano Sarocchi

University of California, Davis

Kari M. Cooper

University of Liverpool

Peter B. Kokelaar

University of Northern

Colorado

Steven W. Anderson

University of Oregon

Ilya N. Binderman

Michael A. Dungan

Daniele Mckay (also with Oregon State University and Oregon State University, Cascades)

University of Portland Kristin Sweeney

University of Tasmania

Martin Jutzeler

Jocelyn McPhie

University of Utah

Jamie Farrell

U.S. Army Corps of

Engineers

Keith I. Kelson

\section{U.S. Forest Service}

Gordon E. Grant (also with Oregon State University)

\section{U.S. Geological Survey}

Charles R. Bacon

Andrew T. Calvert

Christine F. Chan

Robert L. Christiansen

Michael A. Clynne

Michael A. Cosca

Julie M. Donnelly-Nolan

Benjamin J. Drenth
William C. Evans

Judy Fierstein

Cynthia A. Gardner

V.J.S. Grauch

Christopher J. Harpel

Wes Hildreth

Richard P. Hoblitt

Robert A. Jensen

Peter W. Lipman

Jacob B. Lowenstern

Jon J. Major

Seth C. Moran

Lisa A. Morgan

Leah E. Morgan

L.J. Patrick Muffler

Jim O'Connor

John S. Pallister

Thomas C. Pierson

Joel E. Robinson

Juliet Ryan-Davis

Kevin M. Scott

William E. Scott

Wayne (Pat) Shanks

David R. Sherrod

Thomas W. Sisson

Mark Evan Stelten

Weston Thelen

Ren A. Thompson

Kenzie J. Turner

James W. Vallance

Alexa R. Van Eaton

Jorge A. Vazquez

Richard B. Waitt

Heather M. Wright

U.S. Nuclear Regulatory

Commission

Stephen Self (also with University of California, Berkeley)

Washington State University Joseph R. Boro

Owen K. Neill

Stephen P. Reidel

John A. Wolff

\section{Acknowledgments}

Juliet Ryan-Davis and Kate Sullivan created the overview map, and Vivian Nguyen created the cover design for this collection of field-trip guide books. The field trip committee is grateful for their contributions. 


\section{Contents}

Preface

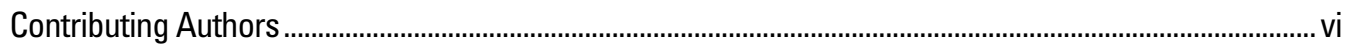

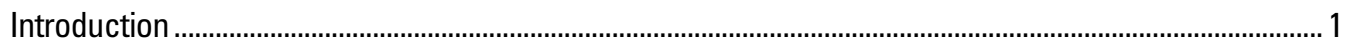

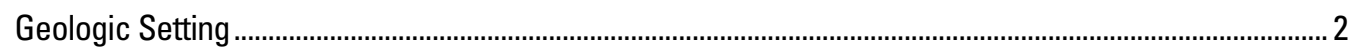

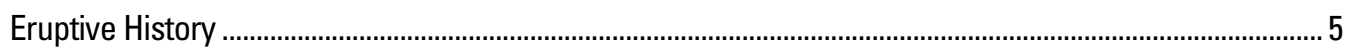

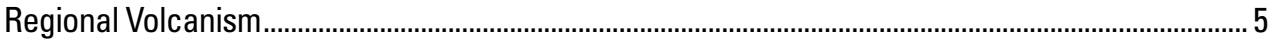

Pre-Mazama Silicic Rocks .......................................................................................................

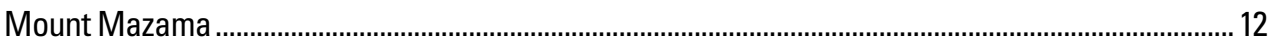

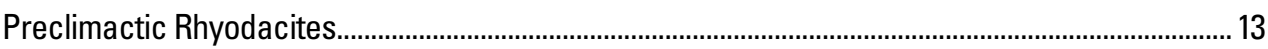

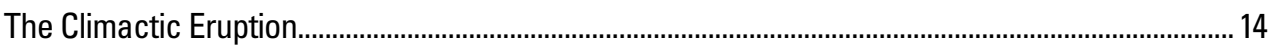

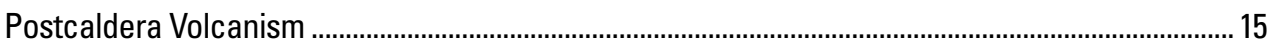

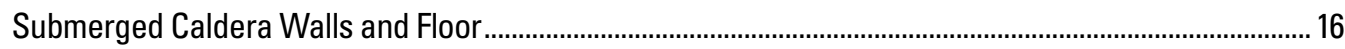

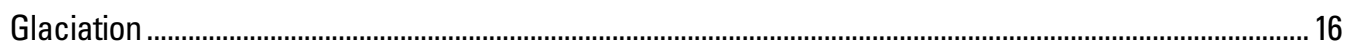

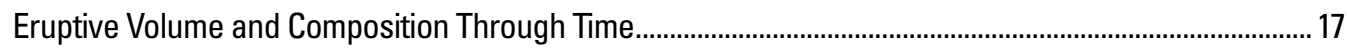

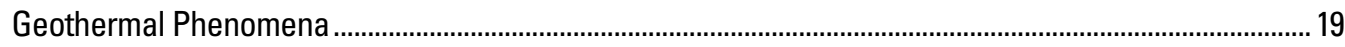

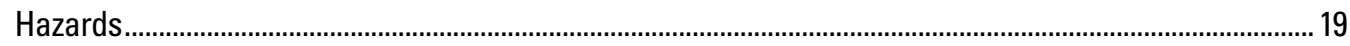

Location and Access ...................................................................................................................... 19

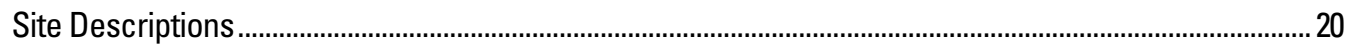

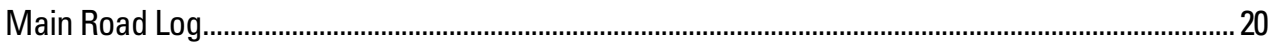

Oregon Route 138 from Roseburg to Crater Lake, Umpqua River Route............................................ 39

Oregon Route 62 from Medford to Park Entrance Road, Rogue River Route ..................................... 40

Oregon Route 230 Between Oregon Routes 62 and 138, Rogue River to Diamond Lake................... 42

Oregon Route 62 from U.S. Highway No. 97 to Park Entrance Road, Klamath Basin Route............. 42

Pumice Fall and Ignimbrite Near U.S. Highway No. 97 South of Chemult............................................ 43

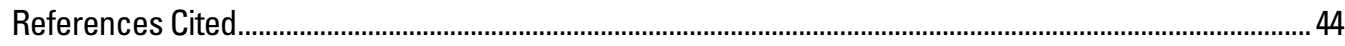

\section{Figures}

1. View from the south-southwest rim of Crater Lake caldera, showing the caldera wall from Hillman Peak on the west, to Cleetwood Cove on the north .................................................................. 1

2. Shaded-relief map showing Mount Mazama and Crater Lake......................................................... 2

3. Variation diagram showing $\mathrm{K}_{2} \mathrm{O}$ and $\mathrm{SiO}_{2}$ contents for $\sim 975$ analyses of rocks from the Crater Lake region

4. Shaded-relief map of Crater Lake, Oregon, region showing Quaternary faults and maximum extent of pyroclastic flow deposits of the 7,700 years before present climactic eruption of Mount Mazama

5. Geologic map of Mount Mazama and surrounding region, adapted from interpretive bedrock map in which glacial and thin pyroclastic deposits are not shown.

6. Geologic panoramas of Crater Lake caldera walls, adapted from Bacon (2008) by inferring

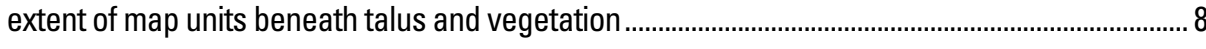

7. Maps showing, in six time slices, assembly of figure 5 geologic map............................................ 9

8. Schematic diagram illustrating depositional order, juvenile clast composition, and facies of deposits of the climactic eruption.

9. Diagram summarizing compositional, thermal, and density (crystals plus liquid) zonation in the magma chamber immediately prior to the climactic eruption. 
10. Model for the evolution of the Mount Mazama magmatic system during growth of the

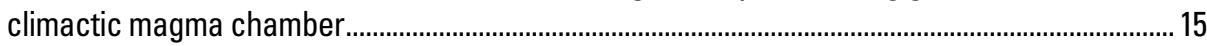

11. Graphs showing silica and volume over time ………................................................................ 18

12. View showing ignimbrite of the climactic eruption at Godfrey Glen ................................................. 21

13. View showing roadcut in lithic breccia bedform near Crater Lake National Park Headquarters, Steel Visitor Center.

14. Schematic sketch showing areal distribution of lithic breccia and pumiceous ignimbrite

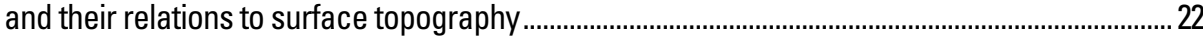

15. View showing roadcut in dacite of Munson Valley fragmental deposits at Stop 3 .......................23

16. View showing the great cliff at Llao Rock that dominates this aerial view and slices into the Holocene rhyodacite lava (Bacon, 2008, unit rh) that filled and overflowed the explosion crater formed in the early stages of the same eruption.

17. View showing the two segments of the Devils Backbone dike that cut all four lava units visible.

18. Aerial view showing The Watchman and Hillman Peak from opposite Devils Backbone ............ 24

19. Perspective underwater view of Wizard Island and central platform volcanoes derived from multibeam sonar bathymetry and U.S. Geological Survey 10-meter digital elevation model....... 25

20. Photograph showing two partly melted granodiorite blocks at Crater Lake Lodge ........................ 25

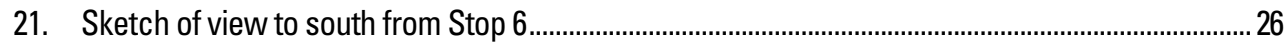

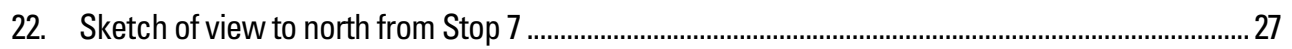

23. Aerial view over Williams Crater cinder cone and Hillman Peak on the west rim of

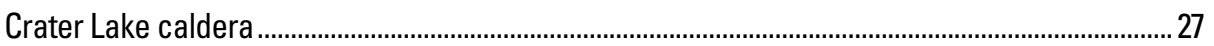

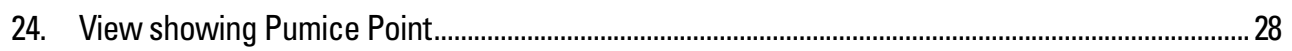

25. Aerial view past Palisade Point showing Cleetwood Cove............................................................29

26. View showing deposits of the climactic eruption exposed in roadcut on East Rim Drive above Cleetwood Cove

27. Schematic north-south section through upper part of Cleetwood flow, showing relations

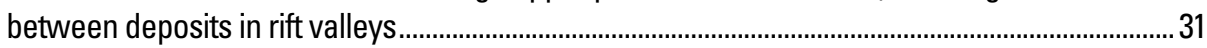

28. View showing deposits of the climactic eruption above Skell Head, the most complete

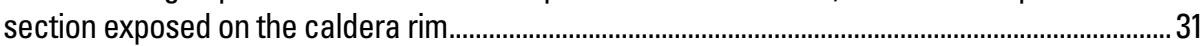

29. Maps showing pyroclastic flow directions and vent locations for $\sim 35 \mathrm{ka}$ and early Holocene eruptives.

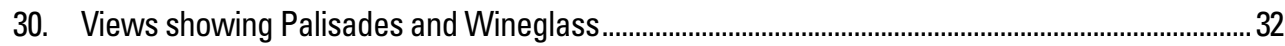

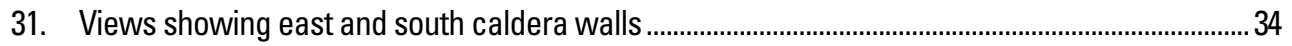

32. View showing spectacular columnar joints in andesite of Applegate Peak vitrophyre

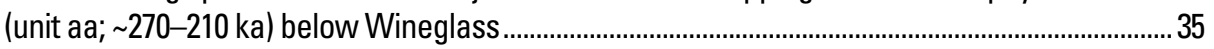

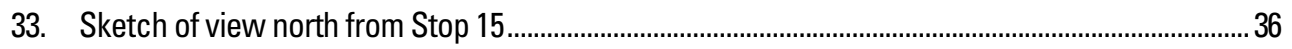

34. View to the north of Pumice Castle, the orange outcrop in the center of the photo, from

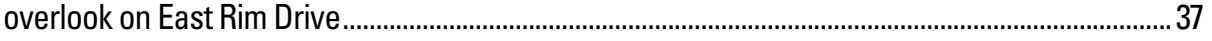

35. View showing The Pinnacles on Wheeler Creek from west end of main exposure ........................37

36. Aerial view of Phantom Ship island and unnamed point in Phantom Cone.....................................38

37. Photographs showing Mazama ignimbrite along Oregon Route 138 ............................................ 39

38. Airborne light detection and ranging (lidar) image showing ignimbrite south of Castle Creek...... 41

39. Airborne light detection and ranging (lidar) images showing normal fault scarps north and south of Castle Creek

40. Photographs showing exposure of climactic pumice fall overlain by distal ignimbrite in South Chemult Pumice quarry. 


\title{
Geologic Field-Trip Guide to Mount Mazama and Crater Lake Caldera, Oregon
}

\author{
By Charles R. Bacon and Heather M. Wright
}

\section{Introduction}

Crater Lake partly fills one of the most spectacular calderas of the world (fig. 1) - an 8 by 10 kilometer $(\mathrm{km})$ basin more than $1 \mathrm{~km}$ deep formed by collapse of the Mount Mazama volcano (fig. 2) during a rapid series of explosive eruptions $\sim 7,700$ years ago. Having a maximum depth of 594 meters (m), Crater Lake is the deepest lake in the United States. Crater Lake National Park, dedicated in 1902, encompasses 645 square kilometers $\left(\mathrm{km}^{2}\right)$ of pristine forested and alpine terrain, including the lake itself, and virtually all of Mount Mazama. The geology of the area was first described in detail by Diller and Patton (1902) and later by Williams (1942), whose vivid account led to international recognition of Crater Lake as the classic collapse caldera. Because of excellent preservation and access, Mount Mazama, Crater Lake caldera, and the deposits formed by the climactic eruption constitute a natural laboratory for study of volcanic and magmatic processes. For example, the climactic ejecta are renowned among volcanologists as evidence for systematic compositional zonation within a subterranean magma chamber. Mount Mazama's climactic eruption also is important as the source of the widespread Mazama ash, a useful Holocene stratigraphic marker throughout the Pacific Northwest United States, adjacent Canada, and offshore. A detailed bathymetric survey of the floor of Crater Lake in 2000 (Bacon and others, 2002) provides a unique record of postcaldera eruptions, the interplay between volcanism and filling of the lake, and sediment transport within this closed basin. Knowledge of the geology and eruptive history of the Mount Mazama edifice, enhanced by the caldera wall exposures, gives exceptional insight into how large volcanoes of magmatic arcs grow and evolve. In addition, many smaller volcanoes of the High Cascades beyond the limits of Mount Mazama provide information on the flux of mantle-derived magma through the region. General principles of magmatic and eruptive processes revealed by geologic research at Crater Lake have been incorporated not only in scientific investigations elsewhere, but also in the practical evaluation of local hazards (Bacon and others, 1997b) and geothermal resources (Bacon and Nathenson, 1996). The 1:24,000-scale geologic map of Mount Mazama and Crater Lake caldera (Bacon, 2008) is unusual because it portrays bedrock (outcrop), surficial, and lake floor geology. Caldera wall geology is depicted in detail on the accompanying geologic panoramas, and bedrock geology is shown in a 1:50,000-scale geologic map. This field guide supersedes earlier geology guides of Crater Lake (Bacon, 1987, 1989). Note that collecting or disturbing rock or other natural specimens in Crater Lake National Park is prohibited except by special permit.

Crater Lake is located on the crest of the Cascade Range of southern Oregon $\sim 90 \mathrm{~km}$ north of the city of Klamath Falls and $\sim 100 \mathrm{~km}$ northeast of Medford. Crater Lake National Park is accessible on the east from U.S. Highway No. 97 (U.S. 97) by way of Oregon Routes 62 and 138 (O.R. 62 and O.R. 138), on

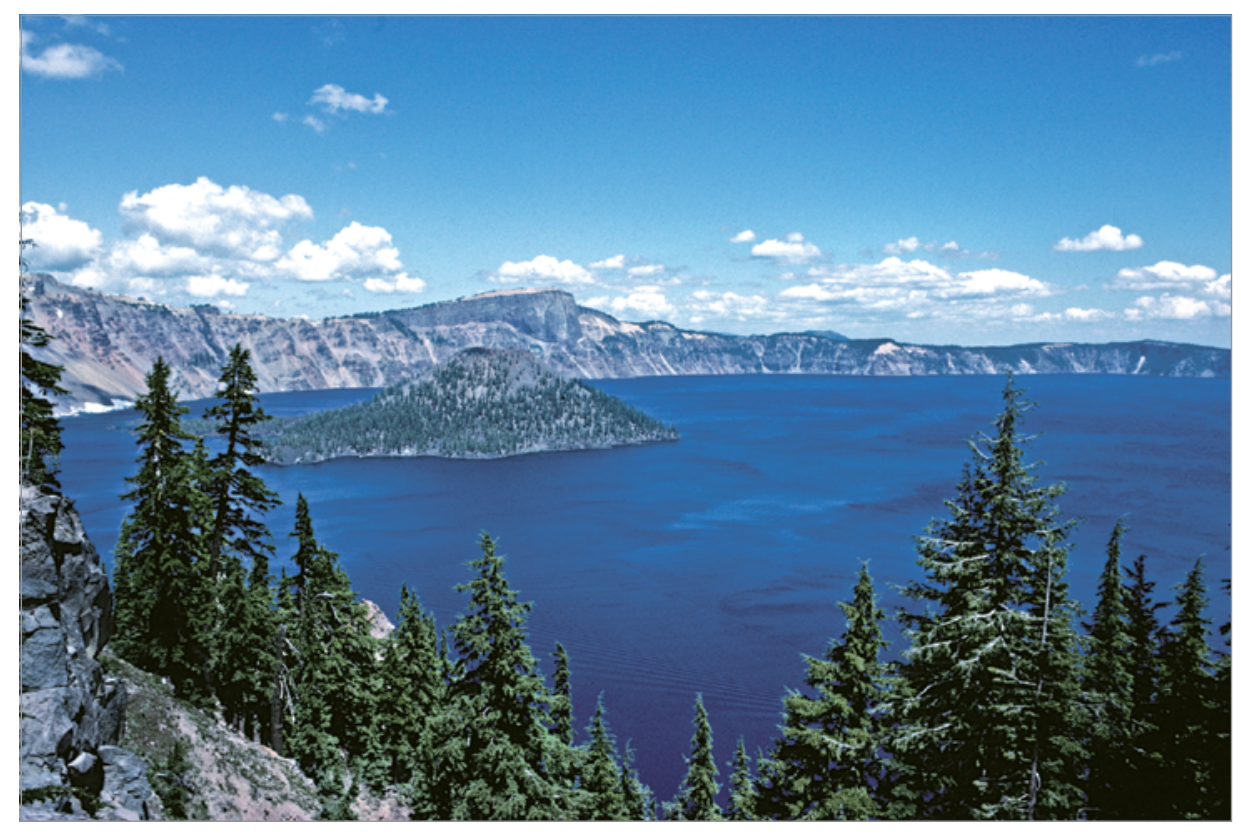

Figure 1. View to the north from the south-southwest rim of Crater Lake caldera, showing the caldera wall from Hillman Peak on the west, to Cleetwood Cove on the north (Bacon, 2008). Crater Lake half fills the 8-by-10-kilometer (km)-diameter caldera formed during the climactic eruption of Mount Mazama volcano 7,700 years ago. Volcanic rocks exposed in the caldera walls and on Mazama's flanks record more than 400,000 years of eruptive history. The cinder cone and andesite lava flows exposed on Wizard Island represent only 2 percent of the total volume of postcaldera volcanic rocks that are mainly beneath Crater Lake. Beyond Wizard Island, the great cliff of Llao Rock (rhyodacite lava emplaced 100-200 years before the calderaforming eruption) dominates the northwest caldera wall where andesite lava flows at the lakeshore are 150,000 years old. 


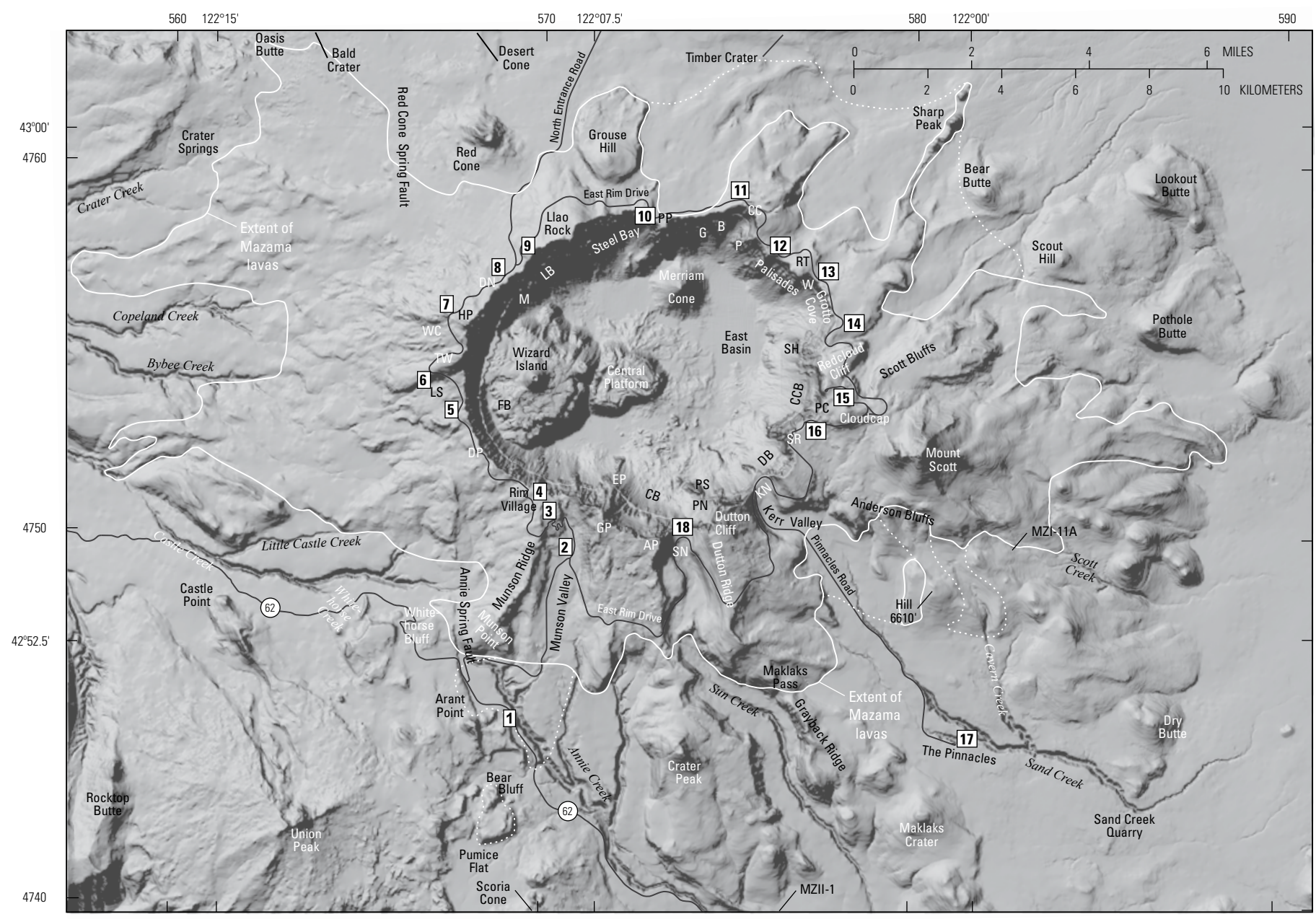

Figure 2. Shaded-relief map showing Mount Mazama and Crater Lake (modified from Bacon and Lanphere, 2006, fig. 3). Extent of lavas of Mount Mazama indicated by solid white line where well defined, by dotted white line where concealed. Topography from U.S. Geological Survey 10-meter digital elevation model; bathymetry from Gardner and others (2001). Field trip stops indicated by numbers in boxes. Place name abbreviations near and within Crater Lake caldera: AP, Applegate Peak; B, boat landing; CB, Chaski Bay; CC, Cleetwood Cove; CCB, Cloudcap Bay; DB, Danger Bay; DN, Devils Backbone; DP, Discovery Point; FB, Fumarole Bay; G, gaging station; GP, Garfield Peak; HP, Hillman Peak; KN, Kerr Notch; LS, Lightning Spring; LB, Llao Bay; M, Merriam Point; P, Palisade Point; PN, Phantom Cone; PS, Phantom Ship; PC, Pumice Castle; PP, Pumice Point; RT, Roundtop; SR, Sentinel Rock; SH, Skell Head; SN, Sun Notch; TW, The Watchman; WC, Williams Crater; W, Wineglass. MZI-11A and MZII-1 are geothermal exploration wells. Tick marks at edge of map are latitude, longitude, and Universal Transverse Mercator (UTM) Zone 10 eastings and northings (km).

the southwest by way of O.R. 62 from the Rogue River valley and Medford, and on the northwest from the Umpqua River drainage and Roseburg by way of O.R. 138. Park facilities are located on the south caldera rim at Rim Village, at the head of Munson Valley, and near Annie Spring. Nearby communities outside the map area are resorts at Union Creek on the southwest, Diamond Lake on the north, and the village of Fort Klamath on the south.

Compositions of lava flows and clasts in fragmental deposits mentioned in this guide and other publications were determined by chemical analysis in U.S. Geological Survey (USGS) laboratories. $\mathrm{SiO}_{2}$ contents are from X-ray fluorescence analyses recalculated to sum to 100 percent volatile free. Rock names are based on silica content: basalt, $\leq 52$ wt. percent; basaltic andesite, 52-57 percent; andesite, 57-63 percent; dacite, 63-68 percent; and rhyodacite,
68-72 percent. K-Ar and ${ }^{40} \mathrm{Ar} /{ }^{39} \mathrm{Ar}$ dates of volcanic rocks (Bacon and Lanphere, 2006) are critical to establishing a stratigraphic framework and quantitative eruptive history. Also of great utility have been determinations of paleomagnetic pole positions for eruptive units by D.E. Champion. Published ${ }^{14} \mathrm{C}$ dates of organic materials constrain the ages of some late Pleistocene and Holocene pyroclastic deposits.

\section{Geologic Setting}

Mount Mazama is in the broad part of the Cascades arc where there are many smaller, or "regional," volcanoes that are the surface expression of melts born in the mantle and escaping to the surface, after undergoing varying amounts of differentiation and 
assimilation, because of a mildly extensional tectonic environment at the west edge of the Basin and Range Province. These regional volcanoes erupted primitive magmas, ranging from high-alumina olivine tholeiite (HAOT; for example, basalt of Castle Point, unit bc) to magnesian basaltic andesite (such as basaltic andesite of Red Cone, unit br), that reflect increasing amounts of subductionrelated fluids or melts added to a depleted mantle source (Bacon, 1990; Bacon and others, 1994, 1997a). The basaltic andesites and more differentiated lavas of Mount Mazama and Crater Lake caldera contain geochemical signatures of most of the range of primitive magmas from regional volcanoes. Magmas erupted in the Crater Lake region range from 47.6 to 73.2 percent $\mathrm{SiO}_{2}$ (fig. 3). Mazama erupted differentiated magmas because the site has long been a magmatic focus and, thus, is relatively warm because of repeated intrusions in the crust. Extensive pre-Mazama dacite and rhyodacite lavas underlie the southern and eastern parts of the edifice (Nakada and others, 1994), and Mount Mazama is (somewhat arbitrarily) defined as the andesite-dacite edifice built upon these $>400$ thousand years before present (ka) silicic lavas.

The underpinnings of Mount Mazama are known from exposures in deep canyons on its south flank, samples of the submerged caldera walls, and drillcore from two geothermal exploration wells (Bacon and Nathenson, 1996). Basaltic andesite and andesitic lava flows and shallow intrusions that represent pre-Mazama regional volcanism are west of the caldera center. Pliocene(?) and (or) early Pleistocene basaltic andesite lava flows form a dissected tableland west of Crater Lake National Park. An exploration well $\sim 7 \mathrm{~km}$ southeast of the caldera shows that preMazama rhyodacite there is underlain by nearly $1 \mathrm{~km}$ of andesitic fragmental rocks and basaltic andesitic lava flows. These flows are underlain by another $0.4 \mathrm{~km}$ of intermediate to silicic tuffs (Bacon and Nathenson, 1996) which may correlate with Tertiary rocks of the Western Cascades. The underlying uppermost crust has been variably altered and metamorphosed by heat and fluid circulation related to intrusion of younger magmas of the Mazama focus. Among these intrusions at a depth of $\sim 5 \mathrm{~km}$ is a late Pleistocene granodiorite porphyry composite pluton at least as extensive as the subsided floor of Crater Lake caldera (Bacon and Lowenstern, 2005). The nature of the deeper crust is uncertain. Isotopic data for Mazama area lavas are consistent with pre-Cenozoic Klamath-type basement rocks but also could be reconciled with younger mafic rocks intruded in response to extension (Bacon and others, 1994). Osmium (Os) isotope ratios of mafic lavas can be modeled by assimilation of young $(\sim-2.5$ million years before present $[\mathrm{Ma}])$

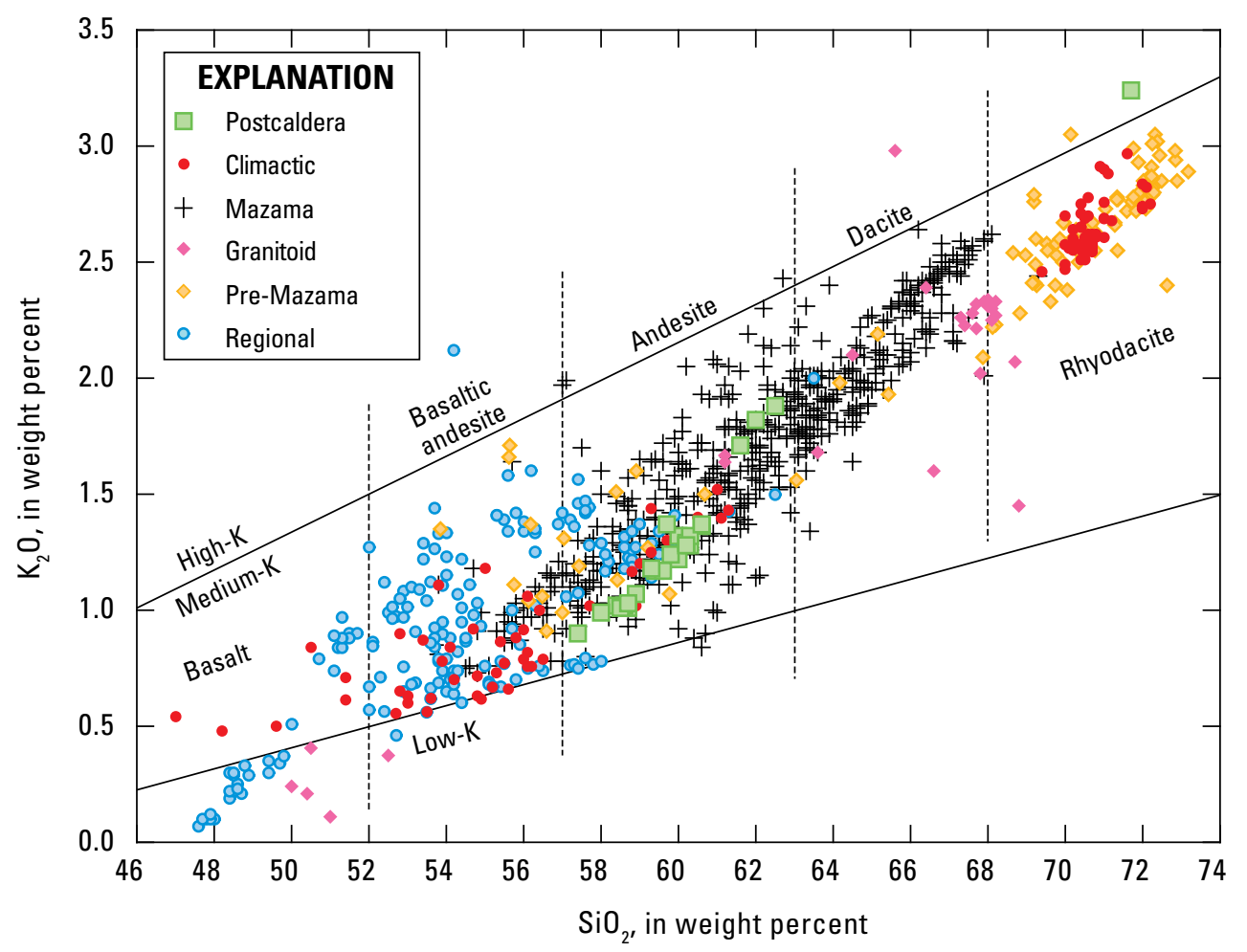

Figure 3. Variation diagram showing $\mathrm{K}_{2} \mathrm{O}$ and $\mathrm{SiO}_{2}$ contents (in wt. percent) for $\sim 975$ analyses of rocks from the Crater Lake region (Bacon and Lanphere, 2006, fig. 1). Plot groups: postcaldera, andesite lavas and rhyodacite dome; climactic, products of climactic magma chamber including climactic pumice, scoria, and cumulate blocks, as well as preclimactic rhyodacites and enclaves; Mazama, lavas, enclaves, pumice, and juvenile-ejecta blocks composing Mount Mazama; granitoid, plutonic blocks (0-50 percent melted) in climactic ejecta; pre-Mazama, silicic lavas and domes, and their enclaves, underlying Mazama lavas; regional, shield and monogenetic cone lavas. Compositional gap in climactic array extends from 61.3 to 69.4 percent $\mathrm{SiO}_{2}$. Major-element analyses by X-ray fluorescence in Denver, Colorado, U.S. Geological Survey (USGS) laboratory, recalculated to sum to 100 percent volatile free. Data from Bruggman and others $(1987,1989,1993)$ and C.R. Bacon (unpublished data, 2005). Low-, medium-, and high-K field boundaries extended from Gill (1981). Basalt, basaltic andesite, andesite, dacite, and rhyodacite classification based on $\mathrm{SiO}_{2}$ content as in previous work at Crater Lake (Bacon, 2008). 


\section{Geologic Field-Trip Guide to Mount Mazama and Crater Lake Caldera, Oregon}

mafic lower crust, whereas Os isotope compositions of silicic magmas can be attributed to assimilation of older ( 16-10 Ma) middle to upper crust related to Western Cascades arc magmatism (Ankney and others, 2016).

Active, generally north-south-striking normal faults traverse the Crater Lake region (Bacon and others, 1997b, 1999; fig. 4), which is part of the Cascade magmatic arc characterized by oblique plate convergence and at the seismically active western margin of the Basin and Range Province. The most prominent fault within the map area is the Annie Spring fault (fig. 2), which is part of the West Klamath Lake fault zone that defines the western boundary of the Klamath graben south of Mount Mazama. This fault zone continues northward as the Red Cone Spring fault and heads for Diamond Lake and Mount Bailey north of the map area. A light detection and ranging (lidar) survey conducted in 2010 (Robinson, 2012) showed that normal faults west of Union Peak and northwest of Mount Mazama are connected by faults draped by climactic ignimbrite. All mapped tectonic faults, except those of the east Klamath

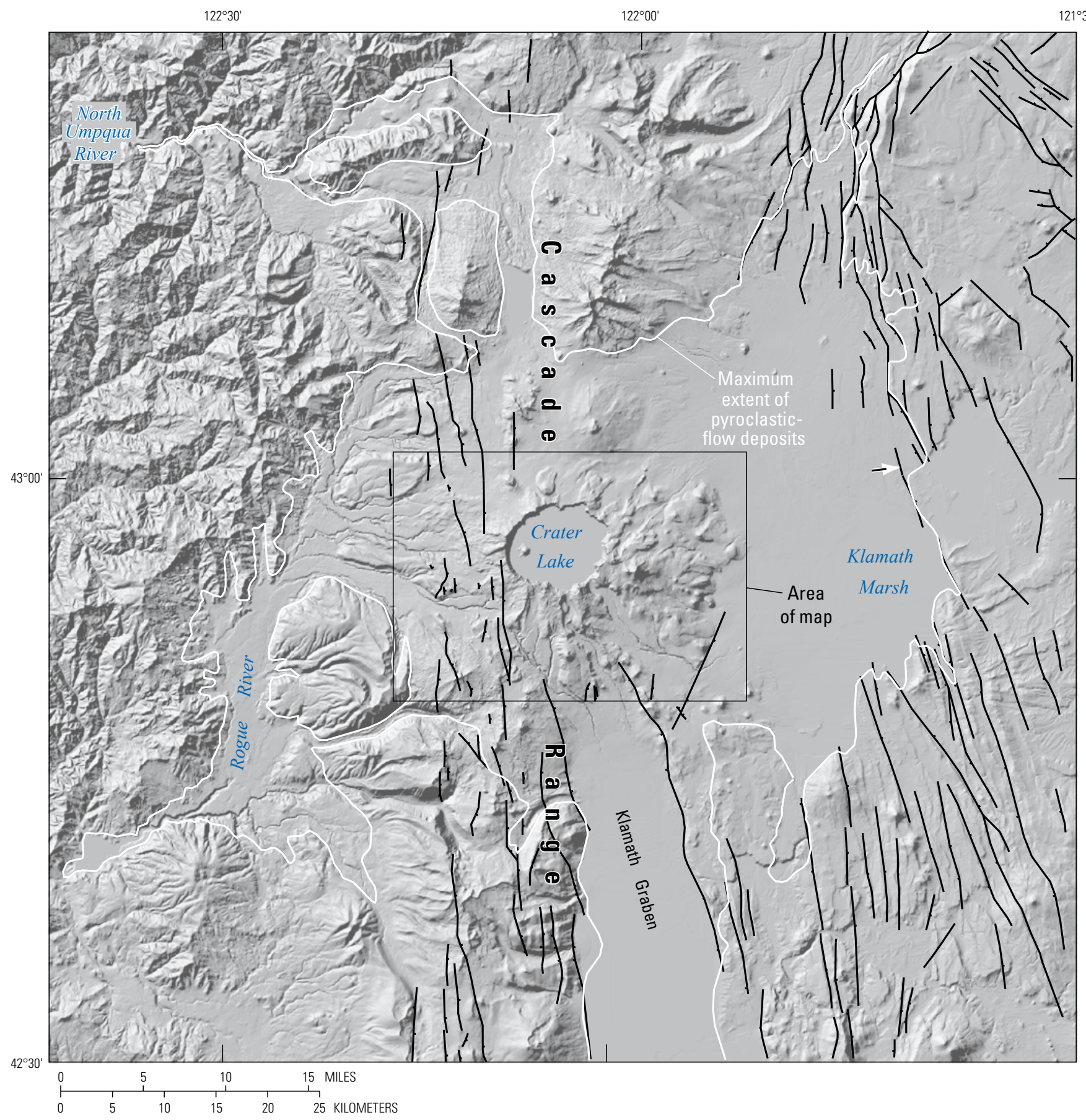

Figure 4. Shaded-relief map of Crater Lake, Oregon, region showing Quaternary faults (heavy black lines; hachures located on downdropped fault block) and maximum extent of pyroclastic flow deposits (white lines) of the 7,700 years before present (yr B.P., where present is A.D. 1950) climactic eruption of Mount Mazama (modified from Bacon, 2008, fig. 2). 
Lake fault zone, have down-to-the-east normal displacement and apparently little strike-slip motion. Vent alignments, particularly of coeval vents, also tend to trend north-south, consistent with regional maximum horizontal compressive stress (east-westopening fractures) away from the vicinity of the Mazama focus.

\section{Eruptive History}

The geologic map and panoramas (figs. 5 and 6) depict stratigraphic relations and constrain volumes of map units fundamental to establishing the eruptive history of Mount Mazama. Including chemical analyses and geochronologic data yields quantitative time-volume-composition information (Bacon and Lanphere, 2006). Many of these units are products of single, short-lived eruptions. Other units, such as the dacite of Pumice Castle (unit dc), are coherent packages of lava flows commonly associated with comagmatic pyroclastic deposits (unit dcp) or intrusions (unit dci), that were erupted from one or more related vents over a period as brief as a few months (?) to as long as thousands of years (for example, dacite of Mount Scott, unit ds). Some units have constituent lavas that are outside the composition range implied by the unit name, which reflects the dominant composition (such as andesite of Applegate Peak, unit aa). Present outcrop areas of volcanic units are shown in figure 7 as six time slices that superimposed make up the geologic map (fig. 5).

Dated samples indicate that regional volcanism has been active throughout at least the past 700,000 years, but continuity of activity prior to $\sim 200 \mathrm{ka}$ is uncertain. Several regional volcanoes, some of them large shields, were active during the interval from $\sim 200$ to $100 \mathrm{ka}$. There was comparatively little regional volcanism between $\sim 100$ and $40 \mathrm{ka}$, whereas during subsequent growth of the climactic magma chamber, voluminous primitive basalt and magnesian basaltic andesite were erupted from several vents west of Mazama. Meanwhile, from $\sim 420 \mathrm{ka}$ to $40 \mathrm{ka}$, Mount Mazama produced andesite and dacite with few discernible gaps in activity but with notable pulses of high productivity. Rhyodacitic magmas were vented only before construction of the Mazama edifice or after $\sim 30 \mathrm{ka}$. Following "leaks" of various preclimactic rhyodacites, the climactic eruption vented much of the differentiated fraction of the shallow magma chamber, resetting the system at its focus $\sim 7,700$ calendar yr B.P. Postcaldera andesites were erupted within a few hundred years of caldera formation, followed by a sole postcaldera rhyodacite dome $\sim 4,800$ calendar yr B.P.

\section{Regional Volcanism}

The Quaternary High Cascades at the latitude of Crater Lake are characterized by dominantly basaltic andesitic lava flows erupted from isolated cinder cones and larger shield volcanoes (Bacon, 1990; Bacon and others, 1994; Bruggman and others, 1989). Although present, andesites and true basalts are less voluminous. These manifestations of regional volcanism apparently underlie the entire area and continue north and south, as well as interfinger with some distal Mazama lavas and overlie others. Successively younger, large shield volcanoes (fig. 5) that are decreasingly eroded include Union Peak (basaltic andesite of Union Peak, unit bu), Timber Crater (andesite of Timber Crater, unit atc), and Scoria Cone (basaltic andesite of Scoria Cone, unit bsc).

Several regional volcanoes show evidence of eruption during glacial times (fig. 5) such as columnar joints formed by local chilling against ice (andesite of Arant Point, unit at), hyaloclastite breccias produced by chilling and fragmentation in intraglacial lakes (basaltic andesite of Whitehorse Creek, unit bwc; andesite south of Bear Bluff, tuff breccia, unit abt), and the gross morphology of volcanic constructs bounded by a regional ice cap. Several tuyas, or table mountains, are recognized (basaltic andesite of Whitehorse Bluff, unit bx; andesite of Arant Point, unit at; andesite south of Bear Bluff, unit ab). Glacial erosion modified nearly all regional lavas and their source vents, commonly exposing the intrusive cores of the vents. Exceptions are Pleistocene cinder cones east of Mount Mazama and Holocene vents near Castle Point (unit bc).

More than 40 source vents for regional lavas were identified within the map area (fig. 5). Lava flows from Crater Peak (andesite of Crater Peak, unit acr), an andesitic cinder cone south of Mount Mazama, cascaded into the canyons of Annie and Sun Creeks around $100 \mathrm{ka}$. Crater Peak lavas resemble some andesites of Mount Mazama, and this cone may be more properly termed parasitic than regional. Red Cone (unit br) is noted for its primitive magnesian basaltic andesitic composition that is the closest representative of mantle-derived magma, highly enriched in incompatible trace elements associated with subductionrelated magmatism (Bacon and others, 1994, 1997a). Williams Crater, named for Howel Williams, produced basaltic andesite contaminated with gabbro (unit bw) and mingled hybrids (mingled lava of Williams Crater, unit $\mathrm{mw}$ ) of the basaltic andesite and genetically unrelated dacite (Bacon, 1990). The youngest regional volcano consists of three early Holocene vents astride Castle Point and associated HAOT lava flows (unit bc).

\section{Pre-Mazama Silicic Rocks}

Domes and thick lava flows of rhyodacite and dacite underlie the Mount Mazama edifice to its south and east (Nakada and others, 1994). Pre-Mazama rhyodacites erupted between 500 and $400 \mathrm{ka}$, probably in a few short-lived episodes. Although commonly mantled by a thick blanket of Holocene pumice-fall deposits (climactic Plinian and other Holocene pumice falls, unit cp; Bacon, 2008) and (or) ignimbrite veneer (climactic fine-grained lithic- and crystal-rich ignimbrite, unit cu; Bacon, 2008), virtually every hill of pre-Mazama rhyodacite is exposed on the caldera-facing part of its summit, because pyroclastic flows of the climactic eruption removed pumicefall deposits and left insufficient veneer or lithic breccia to completely obscure the bedrock. 


\section{Geologic Field-Trip Guide to Mount Mazama and Crater Lake Caldera, Oregon}

\begin{tabular}{|c|c|c|c|c|c|}
\hline \multirow{2}{*}{\multicolumn{3}{|c|}{ LIST OF MAP UNITS }} & \multirow{3}{*}{$\begin{array}{l}\text { Dacite of Steel Bay (I. Pleist.) } \\
\text { Lava }\end{array}$} & \multirow{2}{*}{$d w^{*}$} & \multirow{3}{*}{ Dacite W of The Pinnacles (m. Pleist.) } \\
\hline & & & & & \\
\hline \multirow{2}{*}{\multicolumn{2}{|c|}{$\begin{array}{l}\text { [List of map units shown on maps and (or) panoramas] } \\
\text { SURFICIAL DEPOSITS }\end{array}$}} & \multirow{2}{*}{\begin{tabular}{|c|}
$d s b * /$ \\
$d s b p$
\end{tabular}} & & \multirow{3}{*}{\begin{tabular}{l|} 
blp* $^{*}$ \\
asw \\
\end{tabular}} & \\
\hline & & & \multirow{2}{*}{$\begin{array}{c}\text { Pyroclastic } \\
\text { Andesite of Merriam Point (I. Pleist) }\end{array}$} & & \multirow{2}{*}{$\begin{array}{l}\text { Basaltic andesite } \mathrm{N} \text { of Lookout Butte (m. Pleist.) } \\
\text { Andesite W of Sand Creek (m. Pleist.) }\end{array}$} \\
\hline \multicolumn{2}{|r|}{\begin{tabular}{l|l} 
sl & Sediment gravity-flow deposits (Hol.)
\end{tabular}} & \multirow{2}{*}{$\mathrm{am}^{*}$} & & & \\
\hline $\mathrm{t}$ & Talus (Hol. and Pleist.) & & \multirow{2}{*}{$\begin{array}{l}\text { Andesite of Merriam Point (I. Pleist.) } \\
\text { Andesite of Llao Bay, upper unit (I. Pleist.) }\end{array}$} & \multirow{2}{*}{\begin{tabular}{|l|} 
baf $^{*}$ \\
rcc $^{*}$
\end{tabular}} & \multirow{2}{*}{$\begin{array}{l}\text { Basaltic andesite E of Annie Falls (m. Pleist.) } \\
\text { Rhyodacite W of Cavern Creek (m. Pleist.) }\end{array}$} \\
\hline & & alu* & & & \\
\hline Is & Landslide deposits (Hol.) & $\mathrm{dpt}$ & \multirow{2}{*}{ Dacite of Palisade Point (I. or m. Pleist.) } & \multirow{2}{*}{$\mathrm{dsc}^{*}$} & \multirow[b]{2}{*}{ Dacite of Sand Creek (e. Pleist.) } \\
\hline g & Glacial deposits, undivided (Pleist.) & all* & & & \\
\hline $\mathrm{s}$ & Sedimentary deposits, undivided (I. and m. Pleist.) & $a r^{*}$ & & adsi* $^{*}$ & Andesite S of Dry Butte (e. Pleist.) \\
\hline & & & Andesite of Koundtop (m. Pleist.) & $\mathrm{dd}^{*}$ & Dacite of Dry Butte (e. Pleist.) \\
\hline & VOLCANIC ROCKS & $a m v^{*}$ & Andesite E of Munson Valley (m. Pleist.) & & \\
\hline & Mount Mazama & ags* $^{*}$ & Andesite of the gaging station (m. Pleist.) & & Regional Volcanism, Northwest \\
\hline$r^{*}$ & Rhyodacite of the postcaldera dome (Hol.) & $2 \mathrm{den} *$ & Dacite N of Castle Creek (m. Pleist) & bwn & Basaltic andesite NW of Williams Crater (I. Pleist.) \\
\hline aw & Andesite of Wizard Island (Hol.) & & & bw & Basaltic andesite of Williams Crater (I. Pleist.) \\
\hline amc & Andesite of Merriam Cone (Hol.) & $\mathrm{ag}^{*}$ & Andesite of Garfield Peak (m. Pleist.) & $b^{*}$ & Basaltic andesite of Red Cone (I. Pleist.) \\
\hline & Ander & $\mathrm{dg}$ & Dacite S of Garfield Peak (m. Pleist.) & atc* & Andesite of Timber Crater (I. or m. Pleist.) \\
\hline apc & Andesite of the central platform (Hol.) & $\mathrm{aa}^{*}$ & Andesite of Applegate Peak (m. Pleist.) & $\operatorname{atc}^{n}$ & \\
\hline ae & Andesite of the $\mathrm{E}$ basin (Hol.) & awe & Andesite $\mathrm{E}$ of Wineglass (m. Pleist) & $b_{0}^{*}$ & Basaltic andesite of Oasis Butte (m. Pleist.) \\
\hline$c d$ & Denosits of the climactic eruntion & & & bn & Basaltic andesite $\mathrm{N}$ of Red Cone (m.? Pleist.) \\
\hline & Hol. preclimactic rhyodacite (Hol.) & $\mathrm{ac}^{2}$ & Andesite of Cloudcap Bay (m. Plesst.) & ao & Andesite SW of Oasis Butte (m. Pleist.) \\
\hline $\mathrm{rh} /$ & Lava & $\mathrm{dm}^{*}$ & Dacite of Munson Ridge (m. Pleist.) & bow & Basaltic andesite $\mathrm{W}$ of 0 asis Butte (m.? Pleist.) \\
\hline $\mathrm{rhp}^{*}$ & Pyroclastic & af* & Andesite W of Fumarole Bay (m. Pleist.) & $h^{*} k^{*}$ & Basaltic andesite N of Crater Creek (e Pleist) \\
\hline & Pyroclastic & $\operatorname{arv}^{*}$ & Andesite below Rim Village (m. Pleist.) & $\mathrm{DCK}^{\prime}$ & Basaltıc andesite $\mathrm{N}$ of Lrater Lreek (e. Plesst.) \\
\hline$r s^{*}$ & Rhyodacite of Sharp Peak (I. Pleist.) & $d r^{*}$ & Dacite of Sentinel Rock (m. Pleist) & & Regional Volcanism, Southwest \\
\hline $\mathrm{ab}$ & Andesite S of Bear Bluff (I. Pleist.) & & & $\mathrm{bc}$ & Basalt of Castle Point (e. Hol.) \\
\hline $\mathrm{rbb}^{*}$ & Rhyodacite of Bear Bluff (I. Pleist.) & $a k^{\pi}$ & Andesite of Kerr INotch (m. Plesst.) & blcp & Basaltic andesite $\mathrm{N}$ of Little Castle Ck. (I. Pleist.) \\
\hline re & Evolved Pleist. preclimactic rhyodacite (I. Pleist.) & $d b^{*}$ & Dacite of Chaski Bay (m. Pleist.) & $\mathrm{bsc}^{*}$ & Basaltic andesite of Scoria Cone (I. Pleist.) \\
\hline & & $\mathrm{dpn}$ & Dacite of Phantom cone (m. Pleist.) & & \\
\hline $\mathrm{mw}$ & Mingled lava of Williams Crater (I. Pleist.) & $d s^{*}$ & Dacite of Mount Scott (m. Pleist.) & $b f^{*}$ & Basaltic andesite NW of Pumice Flat (I. Pleist.) \\
\hline $\mathrm{dv}$ & Dacite of Munson Valley (I. Pleist.) & dcc & Dacite of Cavern Creek (m.? Pleist.) & $\mathrm{bu}^{*}$ & 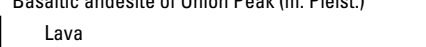 \\
\hline als*/ & Andesite of Lightning Spring (I. Pleist.) & $\mathrm{apn}^{*}$ & Andesite of Phantom cone (m. Pleist.) & bui & Intrusive \\
\hline $\mathrm{asb}^{*}$ & Andesite of Steel Bay (I. Pleist.) & & & & Basaltic andesite of Whitehorse Bluff (m Pleist) \\
\hline 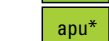 & Andesite of Pumice Point (I. Pleist.) & & Regional Volcanism, East & $b x^{*}$ & (Basaltic andesite of Whitenorse Bluft (m. Pleist.) \\
\hline$a a^{*} /$ & Andesite of Devils Backbone (I. & asc $^{*}$ & Andesite of Scott Creek (I. Pleist.) & $\mathrm{at}^{*}$ & Andesite of Arant Point (m. Pleist.) \\
\hline au & Andesite $\mathrm{S}$ of The Watchman (I. Pleist.) & acr* & Andesite of Crater Peak (I. Pleist.) & bxn & Basalt NW of Whitehorse Bluff (m.? Pleist.) \\
\hline atw $^{n}$ & Dacite of The Watchman (I. Pleist.) & bcsp* & Basaltic andesite S of Crater Peak (I. Pleist.) & baw & Basaltic andesite W of Arant Point (m. Pleist.) \\
\hline dwf'// & Lava & bcnp* & Basaltic andesite $\mathrm{N}$ of Crater Peak (m.? Pleist.) & bbi & Basaltic andesite W of Bear Bluff (m.? Pleist.) \\
\hline dwp & Pyroclastic-flow deposits & $\mathrm{alb}^{*}$ & Andesite S of Lookout Butte (m. Pleist.) & bcw & Basaltic and. W of Mazama Campgr. (m.? Pleist.) \\
\hline$a h^{*}$ & Andesite of Hillman Peak (I. Pleist.) & bsw & Basalt W of Sun Creek (m. Pleist.) & bwc & Basaltic andesite of Whitehorse Ck. (m.? Pleist.) \\
\hline dlp & Dacite below Llao Rock (I. Pleist.) & $\mathrm{bmc}^{*}$ & Basaltic andesite of Maklaks Crater (m. Pleist.) & acc* & Andesite $\mathrm{N}$ of Castle Creek (m. Pleist.) \\
\hline $\operatorname{agc}^{*}$ & Andesite of Grotto Cove (I. Pleist.) & bsr & Basalt of Sand Ridge (m. Pleist.) & $\overline{b c c}$ & Basalt of Castle Creek (m. or e. Pleist.) \\
\hline$b h^{*}$ & Basaltic andesite of Hillman Peak (I. Pleist.) & btp & Basaltic andesite NE of Boundary Butte (m. Pleist.?) & bac & Basaltic andesite of Castle Point (e.? Pleist.) \\
\hline & Dacite of Pumice Castle (I. Pleist.) & $\mathrm{rpb}^{*}$ & Rhyodacite of Pothole Butte (m. Pleist.) & & Basaltic andesite, undivided (Pleist. or Plio.) \\
\hline $\mathrm{dc}^{*}$ & Lava & rcs & Rhyodacite $S$ of Crater Peak (m. Pleist.) & $\mathrm{b}$ & Lava \\
\hline dcp & Pyroclastic & rsc* & Rhyodacite of Scott Creek (m. Pleist.) & bi / & Intrusive \\
\hline bs & Basaltic andesite of Steel Bay (I. Pleist.) & & Andesite of Sand Creek quarry (m.? Pleist.) & & \\
\hline apw/ & Andesite W of Pumice Point (I. Pleist.) & aq & & & Dike \\
\hline$a w w^{*}$ & Andesite of the W wall (I. Pleist.) & aaf* & Andesite NE of Annie $\mathrm{F}$ & & \\
\hline $\operatorname{arw}^{*}$ & Andesite W of Red Cone (I. Pleist.) & bep & Basaltic andesite E of Cavern Creek (m.? Pleist.) & & 0 \\
\hline su & Submerged caldera wall outcrops, undiv. (Pleist.) & acs & Andesite S of Sand Creek (m.? Pleist.) & $\star$ & $\begin{array}{l}\text { Volcanic vent-Does not include dikes feeding } \\
\text { lava flows }\end{array}$ \\
\hline$a b l^{*}$ & Andesite of the boat landing (I. Pleist.) & bdp & Basaltic andesite E of Dry Butte (m.? Pleist.) & $244 \pm 4$ & $\begin{array}{l}\text { Dated sample-Location and age (ka) of sample } \\
\text { dated by K-Ar or }{ }^{40} \mathrm{Ar} / 39 \mathrm{Ar} \text { methods }\end{array}$ \\
\hline $\mathrm{dpe}^{*}$ & Dacite E of Palisade Point (I. Pleist.) & bap & Basaltic andesite of Boundary Butte (m.? Pleist.) & $M Z I-11 A$ & Geothermal exploration well \\
\hline & & as* & Andesite of Sun Creek (m. Pleist.) & & \\
\hline
\end{tabular}

Figure 5. Geologic map of Mount Mazama and surrounding region, adapted from interpretive bedrock map (Bacon, 2008; Bacon and Lanphere, 2006, fig. 2) in which glacial and thin pyroclastic deposits are not shown. Asterisks by unit labels indicate units dated by $\mathrm{K}-\mathrm{Ar}$ or ${ }^{40} \mathrm{Ar} /{ }^{39} \mathrm{Ar}$. First letters of volcanic unit labels indicate composition: $b$, basalt or basaltic andesite; a, andesite; d, dacite; r, rhyodacite. Age abbreviations are as follow: Hol., Holocene; Pleist., Pleistocene; e., early; m., middle; I., late; Plio., Pliocene. Tick marks at edge of map are latitude, longitude, and Universal Transverse Mercator (UTM) Zone 10 eastings and northings (km). See figure 2 caption for place name abbreviation definitions. 
Geologic Setting 7

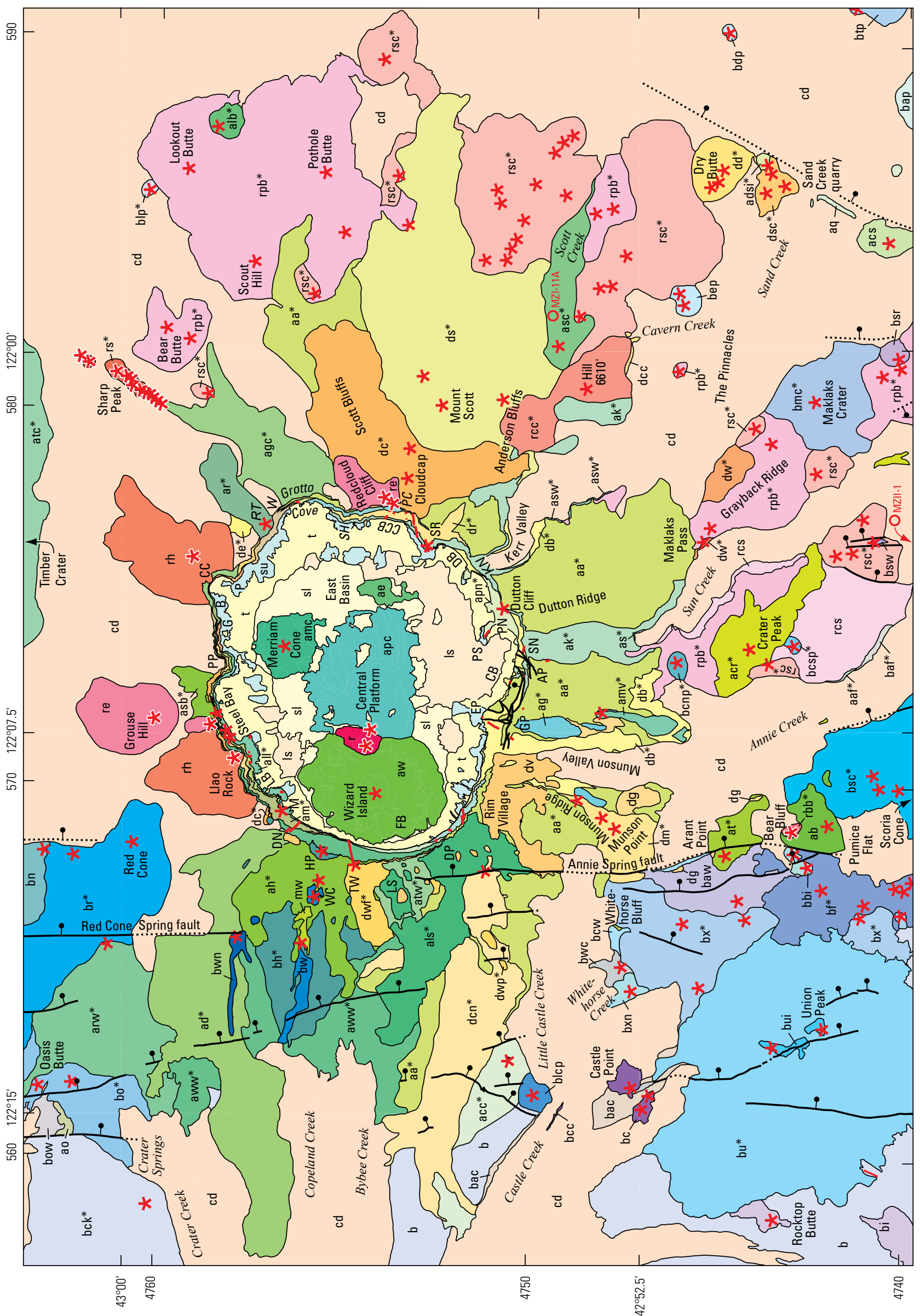




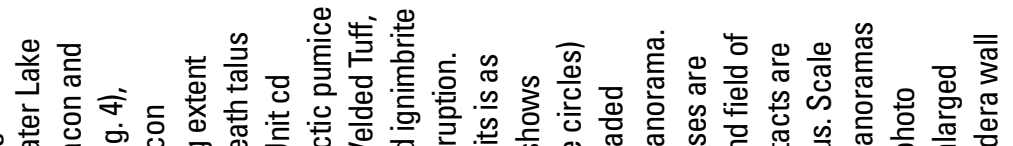
을 离

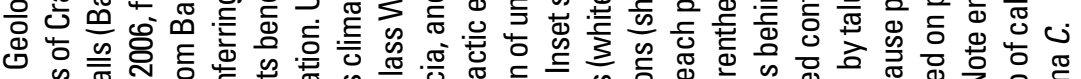
为

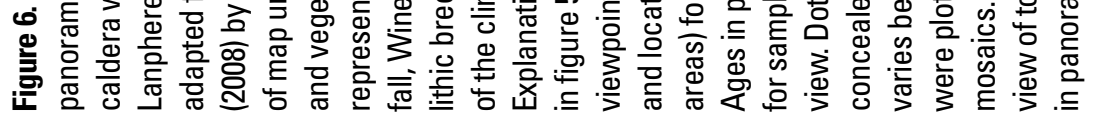
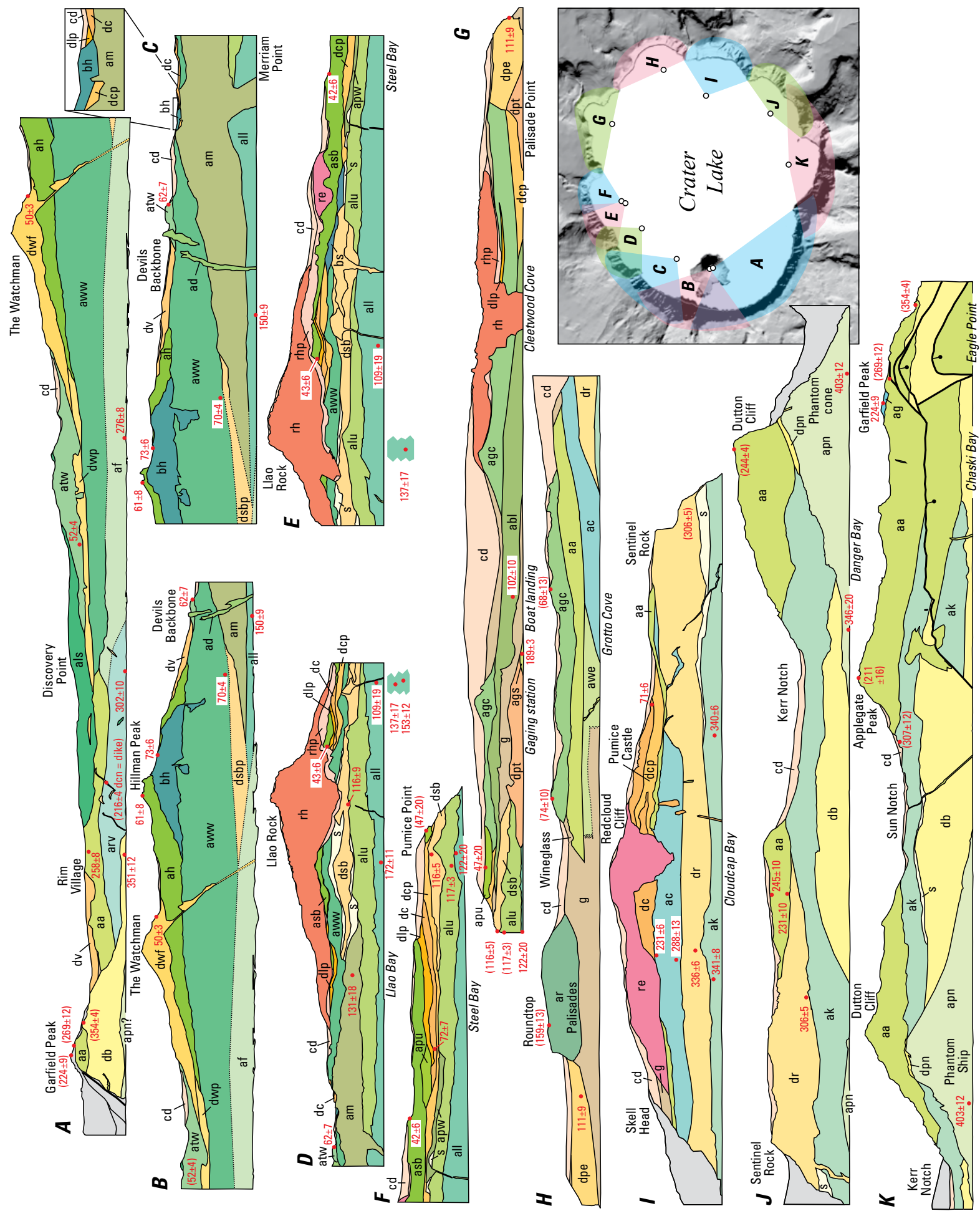
Geologic Setting 9
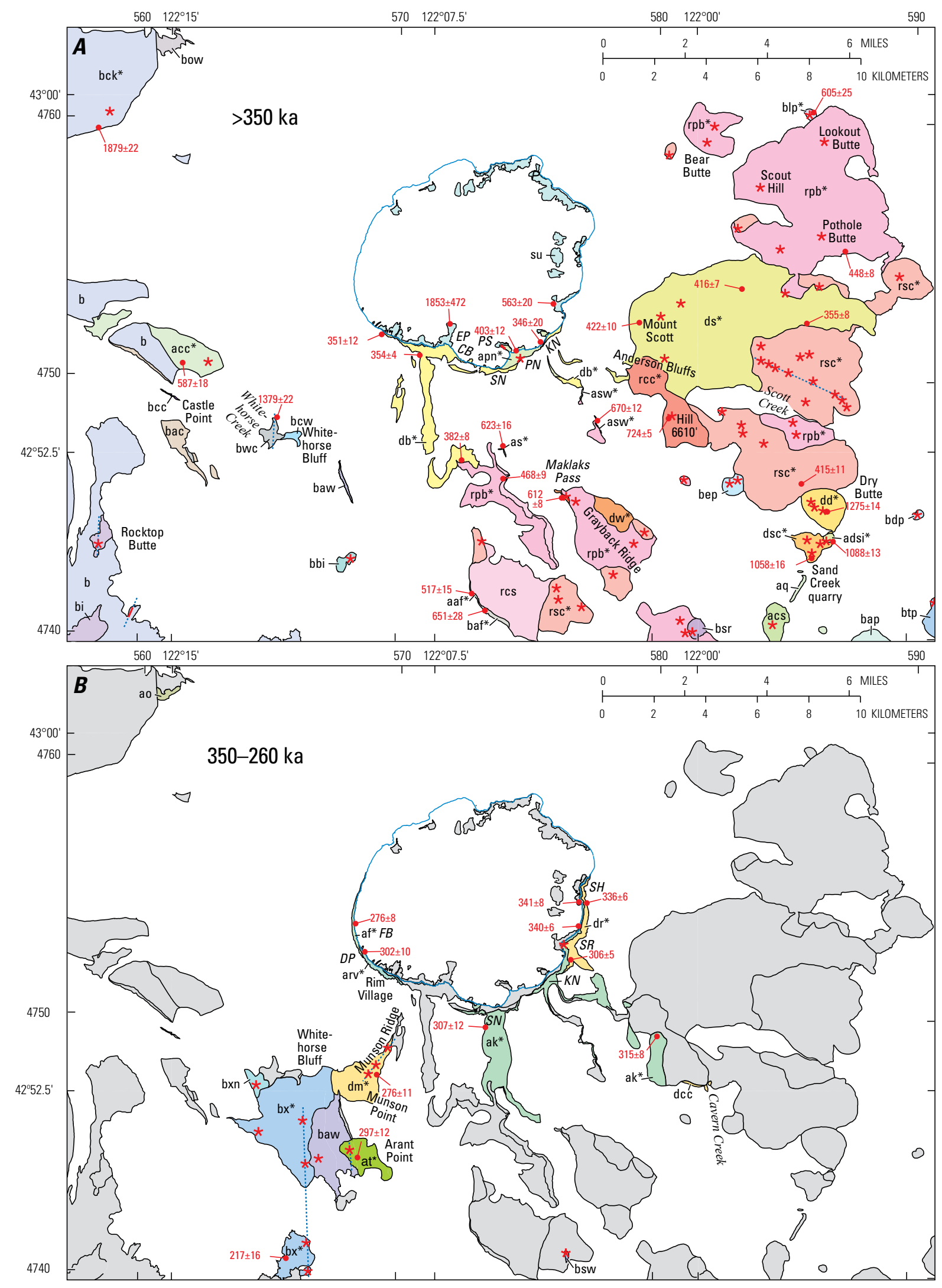

Figure 7. Maps showing, in six time slices, assembly of figure 5 geologic map (after Bacon and Lanphere, 2006, fig. 5). Areas of units have not been reconstructed; faults are omitted. Gray areas in panels B-F depict units emplaced in earlier time slices. Place names and explanation of units is as in figure 5. Present lake shoreline for reference is shown in blue line. Dotted blue lines indicate vent alignments. $A$, Units older than $350 \mathrm{ka} ; B, 350-260 \mathrm{ka} ; C, 260-180 \mathrm{ka} ; D, 180-80 \mathrm{ka}$; $E, 80-40 \mathrm{ka} ; F, 40-0 \mathrm{ka}$. Here, unit cd represents thick climactic ring-vent-phase ignimbrite only. 

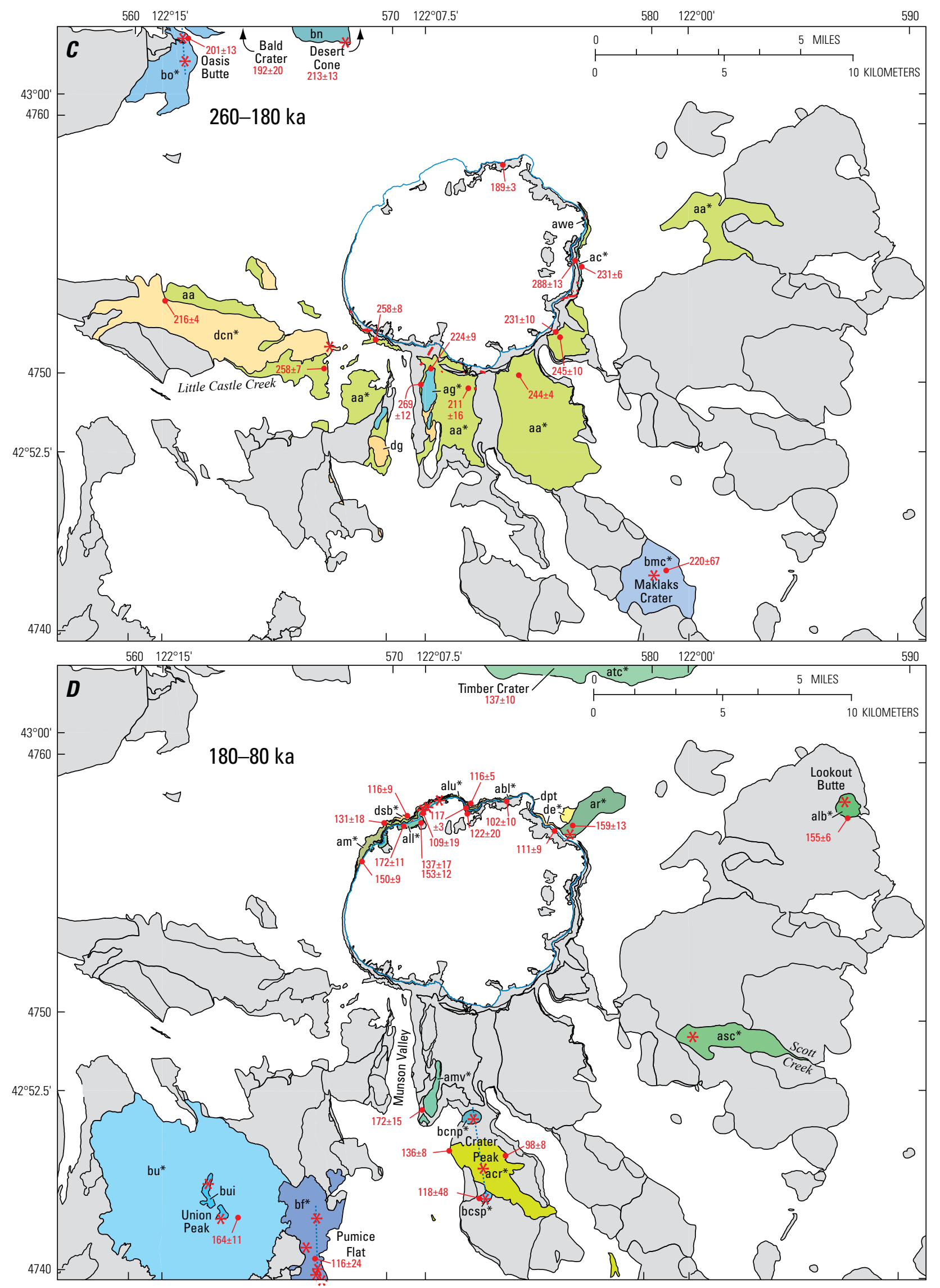

Figure 7.-Continued 

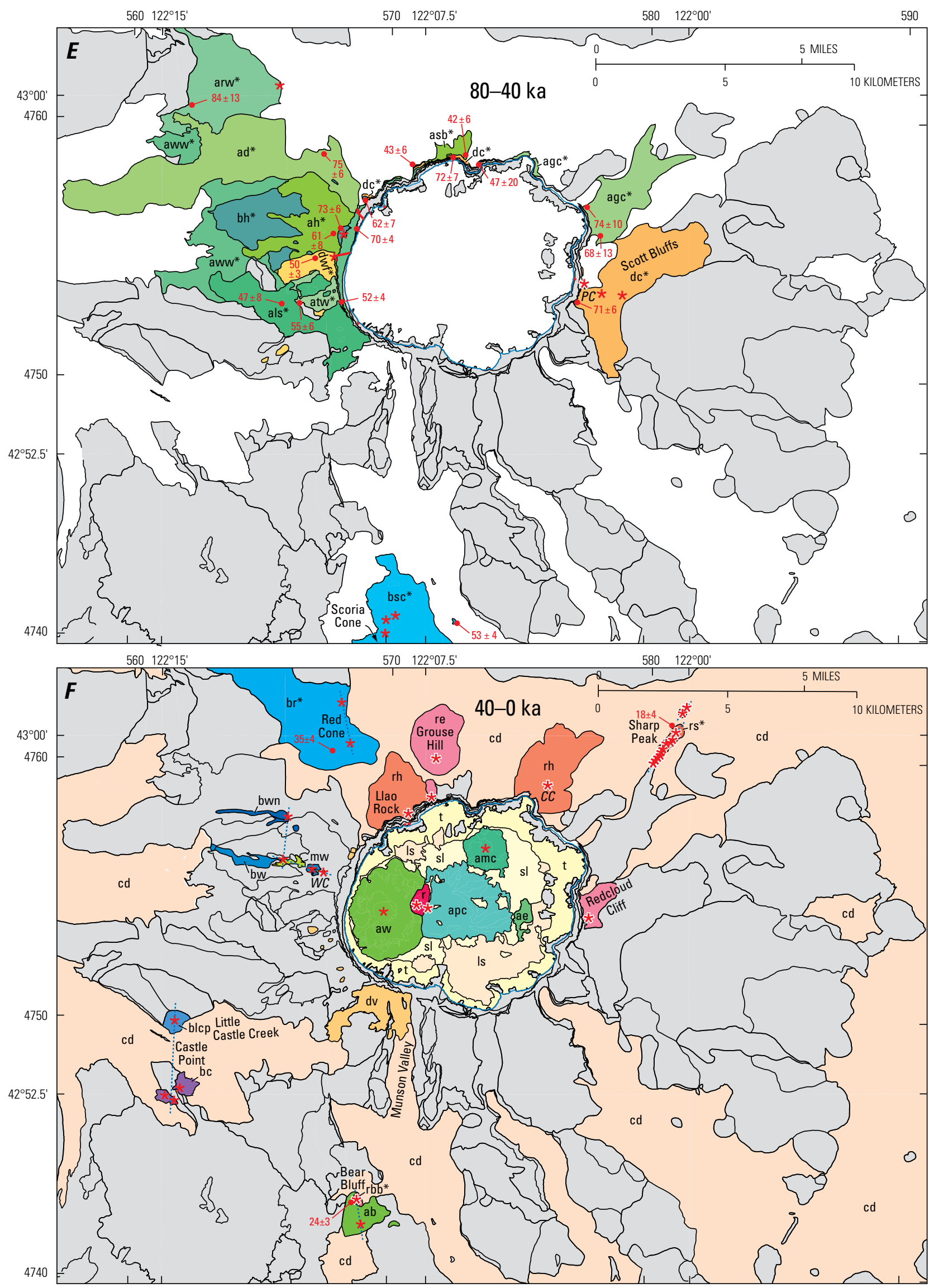

Figure 7.-Continued 


\section{Geologic Field-Trip Guide to Mount Mazama and Crater Lake Caldera, Oregon}

Pre-Mazama rhyodacite units comprise as many as 40 lava flows and domes amounting to a volume of at least $20 \mathrm{~km}^{3}$. At present, there is little evidence for voluminous pre-Mazama rhyodacitic pyroclastic deposits and none for a related buried caldera.

\section{Mount Mazama}

Mount Mazama formerly rose to an elevation of 3,700 m as one of the major volcanoes of the Cascades before its collapse formed Crater Lake caldera (Williams, 1942). Composed almost entirely of lava flows, the bulk of Mazama is andesite and low-silica dacite, whereas dacite and basaltic andesite are subordinate. Erupted magmas had a range of parents characterized by various isotopic compositions and concentrations of elements incompatible in mantle sources (Bacon and others, 1994). Different parental magmas may have imparted different volatile contents (for example, sulfur) on derivative eruptive products (Mandeville and others, 2009; Wright and others, 2012). Like other large, long-lived volcanoes, Mazama is made up of a complex of overlapping shields and stratovolcanoes, each of which was probably active for a comparatively brief interval. Lavas and volcanic deposits of the contiguous edifice that are younger than pre-Mazama rhyodacites are assigned to Mount Mazama, although older andesite and dacite are known from the southern valleys, from limited manned submersible traverses of the submerged caldera walls, and from an exploration well east of Crater Lake National Park.

Superb exposures in the caldera walls and cliffs of glacial valleys provide cross-sectional and longitudinal views of lava flows and pyroclastic deposits. Individual flow units can be traced from proximal agglutinated bomb deposits through streaky lava to distal homogeneous, commonly flow-banded lava (for example, unit aa in Sun Notch and valley walls, and unit ds on Mount Scott). Other examples are thin sheets of mafic andesite (andesite of Cloudcap Bay, unit ac; andesite of Llao Bay, lower unit all). All lavas of Mount Mazama initially had rubbly tops that may amount to as much as half of the total thickness of an eruptive unit. In the southern caldera walls where hydrothermal alteration was most intense, these rubbly tops commonly appear yellowish from a distance, because their high primary permeability allowed relatively intense alteration to clays and minor pyrite; oxidation of the latter colored the flow-top breccia. Bases of lava flows may be strikingly columnar jointed and vitric in their lower parts, especially where lava flowed over damp soil or till (for example, dacite of Sentinel Rock, unit dr, above Danger Bay). A typical lava flow has a zone of subhorizontal platy joints above basal columns or breccia (for example, andesite of the boat landing, unit abl, on the trail above the boat landing). Above the plates may be a relatively massive core surmounted by more platy joints and, at the top, blocky jointed lava grading up into flow-top breccia or rubble. Platy joints may wrap onion-like around the interior of a flow so that plates are steep at flow margins. Lava erupted when ice was present displays ice-contact and water-chilling features, such as closely spaced vitric columns that are $10-20 \mathrm{~cm}$ in cross section (polygonal joints;
Lescinsky and Fink, 2000), often in unusually great thicknesses, and that may grade up into vitric breccia (for example, unit aa on Dutton and Grayback Ridges and at Wineglass; andesite of Llao Bay, upper unit alu, near Pumice Point).

The near absence of volcanic fragmental deposits probably results from late Pleistocene flushing of drainages on the southern and western slopes and burial elsewhere by ignimbrite of the climactic eruption. Extensive pyroclastic flow or volcanic avalanche deposits, such as formed by collapse of lava domes or steep-fronted flows, are represented in only two eruptive episodes (unit dr at Cloudcap Bay; dacite of Munson Valley, unit dv). The only mappable pre-Holocene pumiceous pyroclastic deposits that are part of Mount Mazama are $\sim 70-50$ ka dacite (pyroclastic facies of the dacite of Pumice Castle, unit dcp; dacite below Llao Rock, unit dlp; dacite of The Watchman, unit dwp; fig. 6). Studies of melt inclusions in these rocks indicate that shallow magma may have been stored at depths of 4-7 km since Pumice Castle time, where the role of gas streaming from underplated recharge magma contributed strongly to the gas budget of each eruption (for example, $\mathrm{H}_{2} \mathrm{O}, \mathrm{CO}_{2}$, Wright and others, 2012).

Many dikes are visible in the caldera walls (fig. 6). Several can be traced upward into lava flows (as indicated on the panoramas) or are correlative with lava on the flanks of Mount Mazama. Dikes commonly have glassy selvages with horizontal columnar joints. Irregular intrusions are present below Hillman and Applegate Peaks and in Phantom Cone.

The eruptive history of Mount Mazama, prior to the climactic eruption, spans 400,000 yr (Bacon and Lanphere, 2006; figs. 5-7). The oldest lavas assigned to Mount Mazama are the $\sim 420-400 \mathrm{ka}$ andesite of Phantom Cone (unit apn) and dacite of Mount Scott (unit ds). The andesite of Phantom Cone accumulated near its source vent in the wall southeast of Phantom Ship. Mount Scott is a great pile of low-silica dacitic agglutinate locally rich in andesitic enclaves. The dacite of Chaski Bay (unit db; 380-350 ka), typically containing andesitic enclaves, forms the lower part of the south caldera wall and crops out at the edges of Kerr and Munson Valleys. Extensive, comparatively thin flows of the andesite of Kerr Notch (unit ak; 340-310 ka) also floor Sun Notch and are found from Grotto Cove to below Applegate Peak as far as $5 \mathrm{~km}$ from the caldera rim. Fed by a dike, the dacite of Sentinel Rock (unit dr; $\sim 305$ ? ka) is exposed widely in the caldera wall, fills a glacial valley cut in unit ak south of Sentinel Rock, and lies on glaciated unit ak near Skell Head. South of the present caldera rim, a thick lava flow or set of domes (unit dm; dacite of Munson Ridge) apparently was emplaced between glaciers occupying the drainages of present-day Dutton and Munson Creeks 275 ka. The relatively mafic andesite of Cloudcap Bay (unit ac), approximately coeval with unit $\mathrm{dm}$, forms many thin but extensive agglutinate sheets near its source vent above its namesake where a vertical feeder dike (unit aci; Bacon, 2008) is visible in the caldera wall.

Like other large Cascade volcanoes (such as Mount Adams, Hildreth and Lanphere, 1994), Mount Mazama had episodes of rapid cone building. The most obvious of these episodes produced the andesite of Applegate Peak (unit aa), a compositionally diverse pile of fountain-fed lava flows erupted from the summit vent between $\sim 270$ and $210 \mathrm{ka}$ (mainly $\sim 250-230 \mathrm{ka}$ ). Lava of unit 
aa forms roughly the upper half of the caldera wall between Rim Village and Kerr Notch, is present in the wall as far as Wineglass where there also is an apparently correlative dike (unit aai; Bacon, 2008), and can be traced $5 \mathrm{~km}$ south and $7 \mathrm{~km}$ east and west of the caldera rim. Ice was present during much or all of this episode. A distinctive but kindred dacite flow, erupted from a satellite vent as the dacite south of Garfield Peak (unit dg), is present $5 \mathrm{~km}$ from its source where it is displaced by the Annie Spring fault near Arant Point. Emplacement of unit aa flows southwest of the summit ended by $\sim 225 \mathrm{ka}$ when the hornblende-phyric andesite of Garfield Peak (unit ag) covered part of the south flank of Mazama.

At about $215 \mathrm{ka}$, a flank vent $2 \mathrm{~km}$ west of Rim Village produced uniquely Ti-rich dacitic lava that flowed due west for at least $10 \mathrm{~km}$. Dikes of identical composition (unit deni; Bacon, 2008) in the caldera wall northwest of Rim Village trend directly toward the vent. The magma apparently broke through to the surface when lateral feeder dikes intersected the Annie Spring fault, which now displaces vent agglutinate.

Following 40,000 yr for which no record of Mazama activity is recognized, andesitic magma issued from a flank vent south of Garfield Peak (andesite east of Munson Valley, unit amv) and, independently, different andesitic magma began to construct a large shield where the present Llao Rock is located. This shield volcano grew in two episodes (andesite of Llao Bay, units all and alu) spanning the interval of $\sim 170$ to $120 \mathrm{ka}$. In contrast with the unit all shield, andesite of Roundtop (unit ar) formed a more than 130-m-thick icebounded lava flow at $\sim 160 \mathrm{ka}$ (Lescinsky and Sisson, 1998) at least $2.5 \mathrm{~km}$ long resting on $\sim 115 \mathrm{~m}$ of till and glaciofluvial (?) sediment on the northeast flank of Mount Mazama.

Several andesite and dacite units, emplaced mainly as thick lava flows at about 130-110 ka (dacite of Steel Bay, unit dsb; dacite of Palisade Point, unit dpt; andesite of the boat landing, unit abl; dacite east of Palisade Point, unit dpe; andesite west of Pumice Point, unit apw), are present in the north wall of the caldera. Connecting dikes show that at least some of these units (units dsb and apw) erupted from flank vents. In the northwest wall, andesite of Merriam Point (unit am) forms a mound of thick flows at least $2.5 \mathrm{~km}$ wide and $250 \mathrm{~m}$ thick above its feeder neck. No evidence of eruptive activity is known from the ensuing 100 to $75 \mathrm{ka}$ interval, which was followed by a pulse of vigorous and diverse volcanism.

Beginning at about $75 \mathrm{ka}$ from a source west of the center of the present caldera, andesite of the west wall (unit aww) spread as relatively thin lava flows forming a pile $\sim 300$ m thick below Hillman Peak and extending from Steel Bay to below Discovery Point and at least $7 \mathrm{~km}$ west of the caldera rim in Bybee Creek drainage. By $\sim 70 \mathrm{ka}$, Mazama produced voluminous dacite of Pumice Castle as pyroclastic deposits (unit dep) and lava flows (unit dc). Dikes (unit dci; Bacon, 2008) and welded pumice-fall deposits (unit dcp) north of Pumice Castle mark a major vent area. Extensive lava flows (unit dc) issued from vents east of the caldera rim and flowed to either side of Mount Scott. Similar dacite is present as lava at Steel Bay and above Merriam Point. Immediately above unit dc lava at Steel Bay is a pumice-fall deposit (unit dlp) that is locally welded, indicating a nearby vent.
Evidence for several vents for these dacitic units distributed across $8 \mathrm{~km}$ of the north side of Mount Mazama suggests the presence of a large, contiguous dacitic magma body. Andesite of Grotto Cove (unit agc) issued from a flank vent northeast of Mazama's summit, forming two thick flows that traveled as far as $3 \mathrm{~km}$ northeast of the caldera rim. Joint patterns suggest that these flows banked against ice near the present caldera rim and probably were ice-bounded lava flows. Shortly after these eruptions, hornblendephyric basaltic andesite of Hillman Peak (unit bh) vented from a source exposed in the wall (units bhi and bhp; Bacon, 2008), notably west of the summit of Mount Mazama. Lava flows of unit bh are partially buried by andesite of Hillman Peak (unit ah), which originated from a vent somewhat east of the unit bh vent. The $50 \pm 3 \mathrm{ka}$ Watchman dacite flow (Williams, 1942; dacite of The Watchman, unit dwf) is a prominent feature of the west rim of Crater Lake caldera. Its feeder dike (unit dwi; Bacon, 208) is obvious on the caldera wall. Pyroclastic-flow deposits (unit dwp) of an early phase of the eruption are present in the caldera wall to the south and in rare patches $\sim 4 \mathrm{~km}$ west of Rim Village. Signaling a return to andesite effusion, thick flows of andesite south of The Watchman lava (unit atw; $55 \pm 3 \mathrm{ka}$ ) overlie unit dwp at the caldera rim and also are present north of Devils Backbone, suggesting a source between Hillman Peak and the Mount Mazama summit. A far more voluminous outpouring of andesite of Devils Backbone (unit ad) next took place from a vent or vents fed by the Devils Backbone dike system, creating a flow field on the northwest flank of Mazama extending $11 \mathrm{~km}$ west. Andesites of Lightning Spring (unit als), Pumice Point (unit apu), and Steel Bay (unit asb) are the youngest andesitic lavas known on Mount Mazama. They probably originated at a vent or vents near or west of the Mount Mazama summit 50-40 ka.

The youngest units assigned to the Mount Mazama edifice, both $\sim 35 \mathrm{ka}$, are the dacite of Munson Valley (unit dv) and the dacitic component of the mingled lava of Williams Crater (unit $\mathrm{mw}$ ). Unit dv consists of avalanche deposits fed by a collapsing lava dome(s) or steep flow front(s) high on Mount Mazama. Williams Crater is a basaltic andesitic cinder cone and lava flow complex (unit bw) just west of the caldera rim on the shoulder of Hillman Peak. Mingled dacite and hybrid-andesite lava (unit mw) also vented there and as a tiny dome adjacent to West Rim Drive. Following eruption of these dacites, there is no preserved record of near-summit activity at Mount Mazama.

\section{Preclimactic Rhyodacites}

The caldera-forming eruption of Mount Mazama was preceded by emplacement of several "preclimactic" rhyodacitic lava domes and flows, at least three of which overlie related pyroclastic deposits (Bacon, 1983; Bacon and Druitt, 1988). The oldest, evolved Pleistocene rhyodacite (unit re) includes the Grouse Hill and Redcloud flows (Williams, 1942) and a small dome above Steel Bay. These hornblende rhyodacites were emplaced north and northeast of the summit of Mount Mazama during the last glaciation 30-27 ka and contain abundant crystals derived from partially melted 


\section{Geologic Field-Trip Guide to Mount Mazama and Crater Lake Caldera, Oregon}

Pleistocene granodiorite (Bacon and Lowenstern, 2005). Also emplaced during the glacial maximum, a small dome (rhyodacite of Bear Bluff, unit rbb; $24 \pm 3 \mathrm{ka}$ ) was extruded where a dike, apparently from the Mazama climactic magma chamber, evidently intersected the Annie Spring fault $\sim 8 \mathrm{~km}$ south-southwest of Garfield Peak. Coeval andesite south of Bear Bluff (unit $a b$ ) is compositionally similar to enclaves in unit re flows, suggesting that it also was derived from the Mazama system. Lightly glaciated domes 4-7 km northeast of the caldera (rhyodacite of Sharp Peak, unit rs; $18 \pm 4 \mathrm{ka}$ ) were fed by a dike system emanating from the climactic chamber (Bacon and Druitt, 1988).

The rhyodacitic Llao Rock and Cleetwood flows (Williams, 1942) and associated dikes and pumice-fall deposits (Young, 1990) are Holocene preclimactic rhyodacite (units rh and rhp). It is striking that two Plinian eruptions and subsequent lava flows predate the climactic eruption by less than 100-200 yrs. The Llao Rock products are the older and more differentiated. Llao Rock pumice-fall deposits are widespread southeast of Mazama and the Llao Rock lava flow is spectacularly exposed on the northwest caldera margin. A pumice-fall deposit from the Cleetwood vent underlies the Cleetwood lava flow; these erupted from a distinct vent east of Llao Rock. Identical in composition to climactic rhyodacite, the Cleetwood flow was still hot when the caldera collapsed and remobilized lava oozed down the caldera wall and also flowed northeast for at least an additional kilometer beyond its original terminus. Field relations between Cleetwood lava and various deposits of the climactic eruption demonstrate the precursory nature of the Cleetwood eruption and the timing of caldera collapse (Bacon, 1983; Kamata and others, 1993).

\section{The Climactic Eruption}

The climactic eruption of Mount Mazama devastated the terrain for tens of kilometers from the volcano, sent pyroclastic flows over the slopes of Mazama and into every drainage to travel as much as $70 \mathrm{~km}$ from their source (fig. 4), and produced ash fall throughout much of the Pacific Northwest. At least
90 percent of the $\sim 50 \mathrm{~km}^{3}$ of magma erupted was uniform rhyodacitic pumice (70.5 percent $\mathrm{SiO}_{2}$ ) containing $\sim 10$ percent phenocrysts. The remainder was crystal-rich andesitic scoria and mafic crystal mush (47-61 percent $\mathrm{SiO}_{2}$ ). The eruption took place in two phases (Bacon, 1983; fig. 8): (1) a singlevent phase in which a towering Plinian column rose from a vent northeast of the summit (within the northeast quadrant of the ensuing caldera) and sent pumice and ash to high altitude to be carried by winds, resulting in the widespread fall deposit (Young, 1990; included in unit cd in figs. 5-7); vent widening and increasing eruption rate eventually caused the column to collapse to lower height, producing the pyroclastic flows that deposited the Wineglass Welded Tuff(Williams, 1942; unit cw in Bacon, 2008) in valleys on the north and east flanks of Mount Mazama (Kamata and others, 1993); and (2) a ring-vent phase, which began at the onset of caldera collapse and produced energetic pyroclastic flows, fed by columns rising from a number of vents that circumscribed the foundering cauldron block, and descending radially about Mount Mazama resulting in a compositionally zoned deposit as much as $\sim 100 \mathrm{~m}$ thick (units cf, cb, and cu, ring-vent-phase ignimbrite, lithic breccia, and fine-grained lithic- and crystal-rich ignimbrite, respectively, in Druitt and Bacon, 1986; Suzuki-Kamata and others, 1993; Bacon, 2008). Throughout these deposits, but especially common in unit $\mathrm{cb}$ and at the top of unit $\mathrm{cf}$, are variably fused granodiorite and related accidental lithic blocks (Bacon and others, 1989, 1994; Bacon, 1992) that were derived from a composite pluton (Bacon and Lowenstern, 2005) forming the walls of the climactic magma chamber at $\sim 5 \mathrm{~km}$ depth (Bacon and others, 1992).

The petrology and geochemistry of the climactic ejecta (fig. 9) and preclimactic rhyodacites are described in Bacon and Druitt (1988), Bacon and others (1992), Druitt and Bacon (1988, 1989), and Bruggman and others (1987). The climactic rhyodacite magma was generated mainly by crystallization differentiation of basaltic to andesitic sills repeatedly intruded between cumulate mush and overlying derivative silicic magma (fig. 10). Rapid partial crystallization of sills yielded rhyodacitic
Figure 8. Schematic diagram illustrating depositional order, juvenile clast composition (denoted by italic labels), and facies of deposits of the climactic eruption (modified after Bacon, 1983, fig. 9). Thicknesses not to scale; relative thickness of Wineglass Welded Tuff inferred at right. Ring-vent phase pyroclastic-flow deposits are divided into stages $\mathrm{F} 1, \mathrm{~F} 2$, and $\mathrm{F} 3$, as characterized by componentry variations visible at the surface: $F 1$ contains rhyodacitic juvenile clasts; F2 contains a mixed population of rhyodacitic pumice and andesitic scoria; and F3 contains dominantly andesitic and mafic cumulate scoria (Robinson and others, 2017). These divisions broadly correspond to the silicic (rhyodacite $>80$ percent of juvenile clasts), mixed ( 20 percent $<$ rhyodacite $<80$ percent), and mafic (rhyodacite $<20$ percent) categories of Druitt and Bacon (1986) as seen in valley and caldera wall exposures. Depositional breaks in the zoned climactic ignimbrite are rarely evident. Climactic pumice fall and Wineglass Welded Tuff contain $>99$ percent rhyodacite juvenile clasts.
Caldera rim

$\sim 15$ km

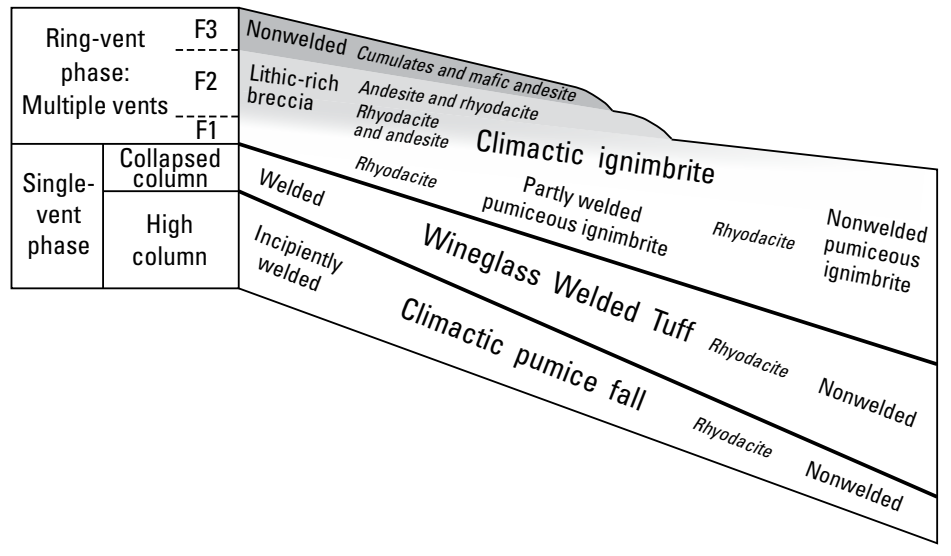


melt that escaped upward, perhaps by gas-driven filter pressing (Sisson and Bacon, 1999), into the convecting silicic magma. Additionally, vapor bubbles from crystallizing recharge magma escaped upward to contribute to the volatile budget of the silicic differentiate. The variety of basaltic to andesitic magmas that participated in this process had a range of incompatible element concentrations, which Bacon and Druitt (1988) indexed by strontium ( $\mathrm{Sr}$ ) content as high-Sr (HSr) and low-Sr (LSr), as well as isotopic compositions (Bacon and others, 1994). The magmatic system grew incrementally over $\geq 20$ k.y. such that, by the time of the climactic eruption, at least $40 \mathrm{~km}^{3}$ of crystal-poor rhyodacite magma overlay a thick, layered cumulate pile. Enclaves in preclimactic rhyodacites represent recharge magmas at various times in the evolution of this system.

Radiocarbon ages of charcoal associated with deposits of the climactic eruption (Bacon, 1983) have a weighted mean value of $6,845 \pm 50{ }^{14} \mathrm{C}$ yr B.P., or a calendar age of $\sim 7,700$ calendar yr B.P. (Stuiver and others, 1998). More recent work by Hallet and others (1997) suggests a somewhat younger age of $6,730 \pm 40{ }^{14} \mathrm{C}$ yr B.P., or 7,470-7,620 calendar yr B.P. Identification of Mazama glass shards in the Greenland Ice Sheet Project 2 (GISP2) core gives 7,627 \pm 150 calendar yr B.P. (Zdanowicz and others, 1999). Although the GISP2 data suggest fine particle fallout for $\sim 3 \mathrm{yr}$, the climactic eruption probably lasted at most a few days. Although there is no written record of its constituent events, this eruption nevertheless has been of fundamental importance to volcanologists in understanding large explosive eruptions, compositional zonation in magma chambers, and collapse calderas (for example, Williams, 1941, 1942). The Crater Lake region is a magnificent laboratory for the study of these natural phenomena because of its ease of access, completeness of geologic record, and excellent preservation of the deposits of the climactic eruption. Zoned ignimbrite in the valleys south and west of the caldera is world famous in volcanology. Exposures along and near East Rim Drive at Cleetwood Cove may be unique in their documentation of the timing of caldera collapse during the various phases of a major explosive eruption. Finally, the fact that the rhyodacitic Cleetwood lava flow was still hot at the onset of the climactic eruption (Bacon, 1983) alerted volcanologists to the possibility of a catastrophic event following close on the heels of a smaller eruption from the same magma source.

\section{Postcaldera Volcanism}

Volcanic activity in the Crater Lake region since the climactic eruption of Mount Mazama has been confined within the caldera. Most volcanic products are hidden from view beneath Crater Lake - Wizard Island amounts to but 2 percent of the total volume of $\sim 4 \mathrm{~km}^{3}$ of postcaldera andesite. Knowledge of postcaldera eruptive history was gained through acoustic mapping of the lake floor (Gardner and others, 2001; Bacon and others, 2002) supplemented by dredged samples and by observation and sampling with a manned submersible (Nelson and others, 1994).

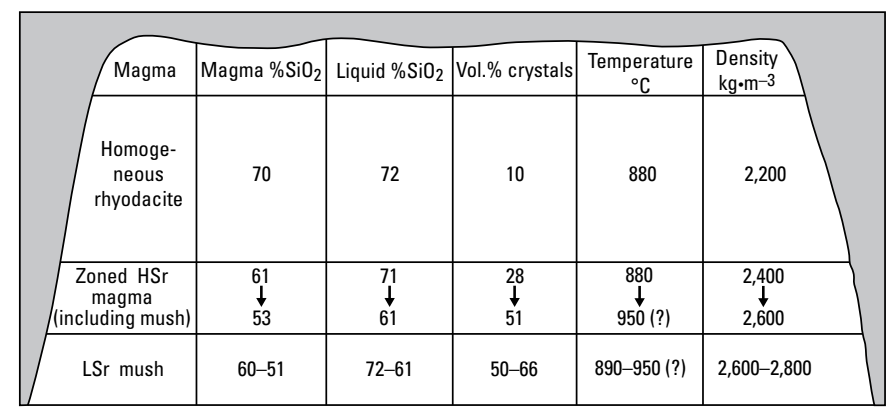

Figure 9. Diagram summarizing compositional, thermal, and density (crystals plus liquid) zonation in the magma chamber immediately prior to the climactic eruption (after Druitt and Bacon, 1989, fig. 13). Abbreviations: HSr, high strontium; LSr, low strontium.

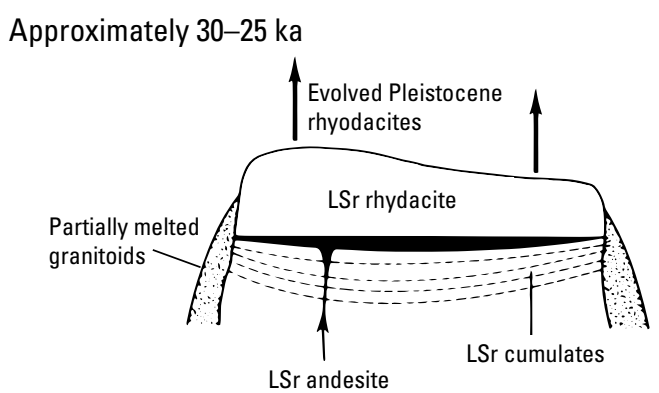

Approximately 25-8 ka

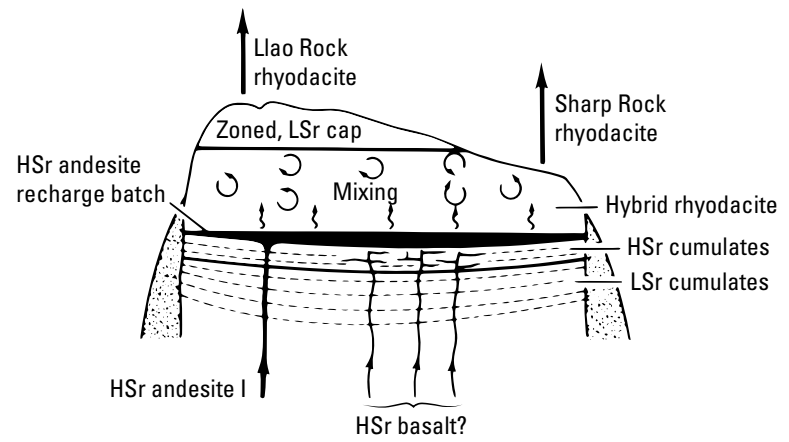

$7.7 \mathrm{ka}$

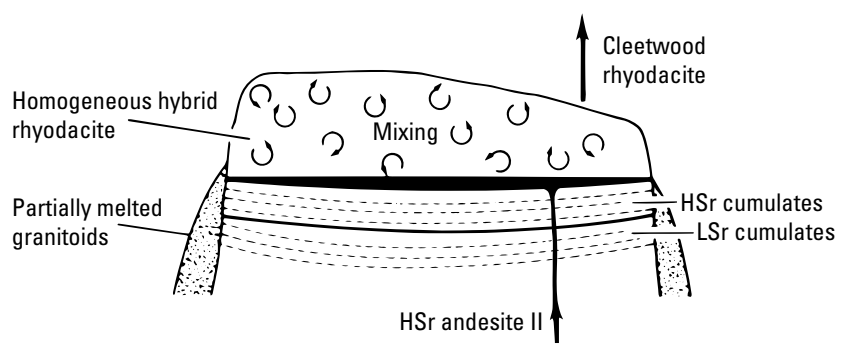

\section{NOT TO SCALE}

Figure 10. Model for the evolution of the Mount Mazama magmatic system during growth of the climactic magma chamber (modified after Druitt and Bacon, 1989, fig. 2). Abbreviations: HSr, high strontium; ka, thousand years before present; $\mathrm{LSr}$, low strontium. 
A major conclusion is that all postcaldera andesitic volcanism took place within a few hundred years of caldera collapse, while Crater Lake was filling to nearly its present level (Nathenson and others, 2007). Products of four andesitic vents are recognized (fig. 5): andesite of the east basin (unit ae), andesite of the central platform (unit apc), andesite of Merriam Cone (unit amc), and andesite of Wizard Island (unit aw). Parts of the last three either vented under water or flowed from then-subaerial vents into the rising lake, leaving a record in foundered shorelines of lava deltas (Bacon and others, 2002). No tephras from these eruptions have yet been recognized on Mount Mazama. The final known postcaldera volcanism resulted in a rhyodacitic ash bed, recovered in a core taken in the lake floor, and extrusion of a subaqueous dome (unit r) on the northeast flank of Wizard Island $\sim, 800$ calendar yr B.P. (Nelson and others, 1994).

\section{Submerged Caldera Walls and Floor}

The multibeam echosounder survey of Crater Lake conducted in 2000 (Gardner and others, 2001) revealed bedrock outcrops of the submerged caldera walls, the surface morphology of debris slopes, and the boundaries of flat-floored basins containing ponded sediment (Bacon and others, 2002).

Crater Lake caldera has a scalloped outline that is typical of collapse calderas. The embayments forming the scalloped pattern are scars formed by landsliding of oversteepened walls, mainly during caldera collapse. Although the slide masses are largely buried in thick caldera fill, the most recent ones appear on the lake floor as hummocky ground characterized by coherent blocks up to several hundred meters on a side (landslide deposits, unit ls; fig. 5). The south wall of the caldera above Chaski Bay is broken by caldera-parallel normal faults into several large blocks that did not slide completely to the caldera floor. Much of the submerged caldera wall is composed of talus and unconsolidated debris (talus, unit t), sloping at least $13^{\circ}$, that commonly is contiguous with subaerial talus (also mapped as unit $t$ ). These debris aprons give way at depth to sediment gravity-flow deposits of the three deep basins (modern sediment of the lake floor, unit sl). Sediment ponds on lava flows and landslides also are mapped as unit sl.

\section{Glaciation}

Glaciated outcrops on the slopes of Mount Mazama, U-shaped notches in the caldera rim at the heads of deep glaciated canyons, and lateral moraines in the lower reaches of the larger valleys have been noted since the classic account of J.S. Diller (Diller and Patton, 1902). Atwood (1935) additionally recognized evidence of multiple glacial advances in buried surfaces within the caldera walls. Williams (1942) promoted Mazama's history of fire and ice. In the years since these pioneering studies, we have developed a refined glacial history of Mount Mazama by using argon geochronology and paleoclimatic records. The deep canyons of Sand, Sun, and Annie Creeks were excavated by repeated ice advances, mainly over lavas no younger than $\sim 210 \mathrm{ka}$; each advance moved debris left by earlier glaciers into Klamath Marsh and Graben (fig. 4), or into major rivers that have transported it out of the area. The north and west caldera rims are not deeply notched, because the comparatively young lava flows present on those flanks have been eroded only by late Pleistocene glaciers. Virtually every hill outside the caldera bears some effect of glacial erosion, except Holocene units and a few Pleistocene lava domes and cinder cones at low elevations near the eastern boundary of the map area. A modest glacial cirque is present on the northwest side of Mount Scott, and all flanks of that edifice have been sculpted by ice. The Union Peak volcano was entirely glaciated so that its intrusive core stands now as a pyramidal horn at the head of a cirque with a deep glacial valley descending northwestward into the valley of Castle Creek. Many pre-Mazama rhyodacite lava flows east of Mount Mazama appear to have been glaciated, perhaps not during the most recent ice advance(s), because most exposures are composed of thoroughly devitrified felsite that commonly forms cliffs at the margins of valleys such as the one south of Pothole Butte.

Glacial till is preserved locally on the slopes of Mount Mazama and is widespread at lower elevations and in the western part of the geologic map. In the field, till is distinguished from volcanic fragmental deposits by presence of abraded durable clasts and an ultrafine component of its matrix. Glacial till and associated fluvial (?) sediments are present in the caldera walls and are shown on the panoramas where they are not covered by talus. An especially thick accumulation below Roundtop and Wineglass appears to be a relatively permeable horizon in the caldera wall that may regulate the level of Crater Lake (Bacon and others, 2002; Nathenson and others, 2007). All of these glacial deposits are collectively mapped as unit $\mathrm{g}$.

At many places in the caldera walls, glaciated lava surfaces have been buried by subsequent lava flows where K-Ar or ${ }^{40} \mathrm{Ar}{ }^{39} \mathrm{Ar}$ dates bracket the time of ice presence (Bacon, 1983; Bacon and Lanphere, 2006). Similarly, ice contact features (Lescinsky and Fink, 2000) are common in some units (for example, unit aa). The table mountain or tuya morphology and structure (Mathews, 1947) of some monogenetic volcanoes near Mount Mazama also indicate presence of ice of a specific minimum thickness at the time of eruption (units at and ab). Although it is feasible that alpine glaciers were present, at least at high elevations, on Mount Mazama at virtually any time between $\sim 400 \mathrm{ka}$ and $\sim 7.7 \mathrm{ka}$ (caldera collapse), it seems likely that dated times of ice presence correlate with wellestablished glacial intervals tied to paleoclimatic chronologies such as marine oxygen isotope stages (Bowen and others, 1986; Martinson and others, 1987).

Reconstructions of Mount Mazama show a 3,700m-elevation volcano (Diller and Patton, 1902; Atwood, 1935; Williams, 1942). There is not a compelling reason to revise this estimate. Three paintings by Paul Rockwood 
under direction of Howel Williams (for example, Briggs, 1962) depict (1) Pleistocene Mazama sheathed in ice; (2) the volcano at the onset of its climactic eruption; and (3) the freshly collapsed caldera in a pumice-mantled, devastated landscape. The middle painting in the sequence portrays Mazama with ice-clad upper slopes and glaciers descending to $\sim 1,900 \mathrm{~m}$ in the southern valleys, whereas the last painting retains beheaded glaciers in Munson Valley and Sun and Kerr Notches. The Rockwood paintings are excellent representations of a modern view of the late history of Mount Mazama with the principal exceptions of the climactic eruption initiating at the summit, the extent of Holocene ice, and the presence of remnant glaciers following caldera collapse. These features evidently were included because Williams interpreted deposits now mapped as lithic breccia (unit cb; Bacon, 2008) as probable glacial till. Improved knowledge of pyroclastic deposits negates the till hypothesis. Moreover, paleoclimatic reconstructions indicate that at the time of the climactic eruption, a relatively warm and dry period, any ice would have been restricted to the highest part of Mount Mazama, and its south flank, especially, would have been ice free at elevations of the caldera rim.

\section{Eruptive Volume and Composition Through Time}

A major result of geologic study of Mount Mazama and the surrounding region is documentation of ages, volumes, and compositions of eruptive units (Bacon and Lanphere, 2006; Bacon, 2008). Burial of older units by younger ones and repeated glacial erosion complicate estimation of volumes and produce ever-larger uncertainty for units of increasing age. Pyroclastic and laharic material deposited on ice or in valleys, and thin intracanyon lava flows, would have been removed by glacial advances. Absolute durations of volcanic episodes are poorly known because of analytical uncertainties in bracketing ages. Consequently, the record is incomplete and fragmentary, and interpretations below are subjective.

In simplest terms, Mazama vented less than 1 percent basaltic andesite, 42 percent andesite, 15 percent dacite, and 43 percent rhyodacite in its lifetime. Prior to $30 \mathrm{ka}$, there was no rhyodacite, and the proportion of andesite to dacite was $2: 1$. In the same period, regional lavas were less than 1 percent basalt, 58 percent basaltic andesite, and 42 percent andesite, the Timber Crater shield accounting for nearly all andesite. The distribution of average or bulk compositions of units through time was not uniform. After an 70,000-year initial dacite-dominated period, Mazama produced mainly andesite until it again vented a substantial volume of dacite at $70 \mathrm{ka}$. Rhyodacite did not appear until $\sim 27 \mathrm{ka}$ and thereafter was dominant until postcaldera time when andesite accounted for 98 percent of the erupted volume.

Although units are named for representative compositions (figs. 5 and 6), the range of compositions within many units is substantial (fig. 11A). Following eruption of pre-Mazama rhyodacites, maximum $\mathrm{SiO}_{2}$ from 420 to 110 ka was 67 percent. Subsequently, $\mathrm{SiO}_{2}$ climbed to 68 percent at $\sim 70 \mathrm{ka}$ and $>70$ percent after $30 \mathrm{ka}$. From 400 to almost $30 \mathrm{ka}$, at least some andesite lava was erupted in virtually every episode, and many episodes produced mafic andesite lava or enclaves that extend the silica range at the Mazama focus down into that of regional lavas. Excepting enclaves in mingled lava at Williams Crater and cumulate blocks in the climactic ejecta, the most mafic samples are regional lavas. These observations are the basis for the model in which the Mazama focus was fed by parental magmas similar to those erupted from regional monogenetic and shield volcanoes, and that the magma composition erupted at Mazama at any given time was a consequence of a particular combination of crystallization differentiation, magma mixing, and recycling of cumulates and plutonic material.

As at Mounts Adams and Baker (Hildreth and Lanphere, 1994; Hildreth and others, 2003), major additions to the Mazama edifice occurred in a few pulses (fig. 11B). These pulses may have been similar to the onset of the $\sim 80-30 \mathrm{ka}$ record in which a high eruption rate lasting 10-15 kyr was followed by a background rate an order of magnitude lower. Major pulses in regional volcanism reflect growth of Union Peak and Timber Crater shield volcanoes above a background of monogenetic volcanism.

The pulses in eruption rate could be caused by variations in magma supply from the mantle or by changes in the upper crustal environment induced by tectonic stress or glacial loading. Isotopic and trace-element compositional variation among major eruptive units (Bacon and others, 1994) indicates that each had its own, commonly unique, mantle-derived parent magma(s).

At least some pulses in the Mazama plot (fig. 11B) may relate to rapid deglaciation following marine isotope stages (MIS) 12, 10, 8, 6, 5.2, and 2. The Timber Crater volcano possibly generated a large volume of andesite because ice loading during the long penultimate glaciation (MIS 6) promoted storage and differentiation, and this magma vented when the ice rapidly melted. Additionally, deglaciation may have induced decompression melting in the mantle, leading to increased magma flux into the crust. In the case of the climactic magma chamber, only the lateral-dike-fed vents at Bear Bluff and the Sharp Peak domes were active around the time of the LGM (MIS 2) when ice must have been present on Mazama and its flanks (assuming the $\sim 27 \mathrm{ka}$ age of unit re is correct). Although there are many examples globally of voluminous silicic eruptions in areas free of glacial influence, and the more voluminous Holocene rhyodacitic eruptions at Mazama followed ice retreat by several thousands of years, suppression of volcanism by ice loading may have contributed to accumulation of the large volume of vapor-saturated rhyodacitic magma that ultimately vented in the climactic eruption. An increase in mantle supply rate, as inferred by time-averaged eruptive rates over thousands of years, may have contributed to growth of the large magma reservoir in the thermally primed upper crust, consistent with spatial and temporal evolution of eruptions over $50 \mathrm{kyr}$ preceding caldera formation (Karlstrom and others, 2015). 


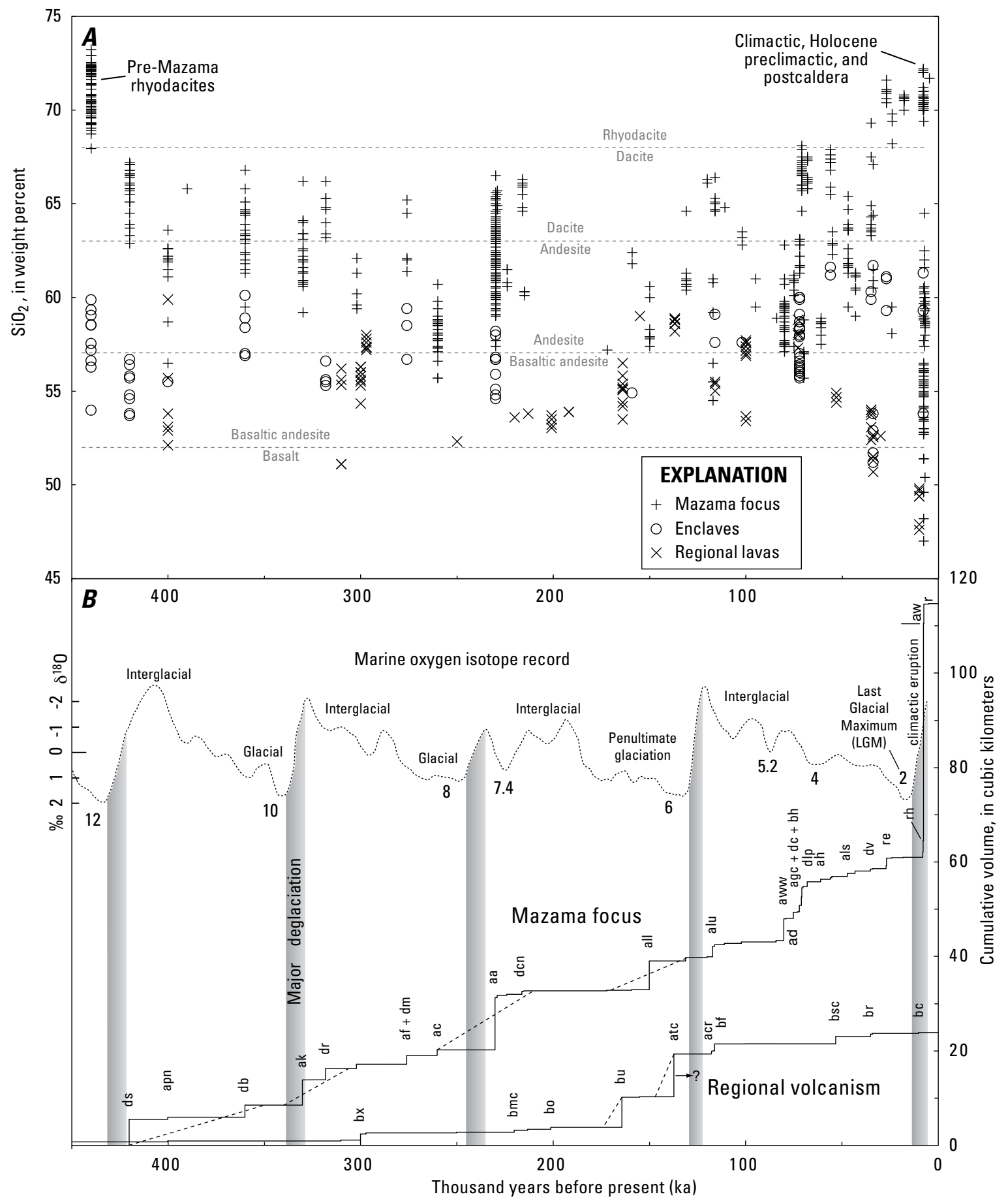

Figure 11. Graphs showing silica and volume over time (after Bacon and Lanphere, 2006, fig. 7). Data for some units plotted at representative or assumed times (for example, regional lavas at $400 \mathrm{ka}$ ). $A$, Whole-rock $\mathrm{SiO}_{2}$ content, same dataset as for figure 3 . All samples from individual units plotted at single times even though eruptive durations for some units may have been substantial. Pre-Mazama rhyodacites (units rsc, rcs, rpb) and their enclaves plotted for reference at $440 \mathrm{ka}$. Holocene Mazama-focus samples with $\leq 55$ percent $\mathrm{SiO}_{2}$ are crystal cumulates; most climactic samples with $\leq 61$ percent $\mathrm{SiO}_{2}$ probably have lost some melt. Enclaves typically are frozen, undercooled, phenocryst-poor magma; however, of those plotted at $72 \mathrm{ka}$, all but the most silicic have lost residual melt by gas-driven filter pressing. $B$, Cumulative magma volume erupted over time for Mount Mazama and for regional shield and monogenetic volcanoes. Volumes are estimates for reconstructed mapped units; total Mazama edifice volume was greater (see Bacon and Lanphere, 2006). Volumes of individual units plotted at representative times. Possible durations of some major eruptive episodes indicated by dashed segments of cumulative volume plot. Marine oxygen isotope record (Bassinot and others, 1994, fig. 7) with selected numbered marine isotope stages (MIS) for reference. Major continental deglaciations indicated by shaded vertical bars. 


\section{Geothermal Phenomena}

Widespread alteration of rocks older than $\sim 120 \mathrm{ka}$ exposed in the caldera walls attests to hydrothermal circulation within ancestral Mount Mazama. Postcaldera thermal features probably are related to residual heat from the climactic magma chamber. The chemistry of water in Crater Lake requires input of thermal fluid through the caldera floor (Bacon and Nathenson, 1996). Areas of high convective heat flow caused by circulation of such fluid were delineated by heat flow measurements by D.L. Williams (Williams and Von Herzen, 1983). Exploration of these areas with a manned submersible documented numerous bacterial mats north of Eagle Point that have elevated internal temperatures, as well as small pools of warm, solute-laden water below Cleetwood Cove (Dymond and Collier, 1989; Bacon and others, 2002). Many independent lines of evidence indicate that thermal fluid is entering Crater Lake through its floor, increasing the temperature subtly at the sediment-water interface, and causing the lake to convectively mix on a time scale of $\sim 3$ years (Williams and Von Herzen, 1983; Wheat and others, 1998). Higher temperature fluid apparently vented through the lake floor in the past, as one submersible traverse encountered fossil subaqueous thermalspring deposits in the form of silica spires as high as $10 \mathrm{~m}$ at $\sim 550 \mathrm{~m}$ depth off Skell Head (Bacon and others, 2002).

Two geothermal exploration wells were drilled by California Energy Company, MZI-11A (1,423 m deep) just east of the park boundary in the Scott Creek drainage and MZII-1 (867 m deep) south of the boundary and east of Annie Creek (fig. 2; Bacon and Nathenson, 1996). Drill core samples of regional mafic lavas from the southern well are relatively fresh and the maximum temperature measured was $40^{\circ} \mathrm{C}$, whereas hydrothermal alteration is ubiquitous in core samples from the eastern well, which had a maximum temperature of $130{ }^{\circ} \mathrm{C}$ and intersected more compositionally diverse rocks. Bacon and Nathenson (1996) suggested that the geothermal system responsible for the $130^{\circ} \mathrm{C}$ temperature from MZI11A is small and may be powered by residual heat from intrusions related to the dacite of Pumice Castle (unit dc).

\section{Hazards}

The climactic eruption and collapse of Crater Lake caldera so dramatically changed the character of Mount Mazama volcano that many potential types of future eruptions have no precedent there (Bacon and others, 1997b). Future eruptions may occur within the lake in shallow water, eject ballistic blocks and ash outside the caldera, and result in downwind (predominantly eastward) tephra fall or generation of pyroclastic surges. Eruptions from vents in deep water would be expected to be much less violent. The 30-year probability of renewed volcanic activity within or very near to the caldera is greater than 1 chance in 330 , or $3 \times 10^{-3}$ (Bacon and others, 1997b). Should an eruption eject lake water from the caldera, abundant loose debris left by the climactic eruption on the upper slopes of Mount Mazama and in the valleys might be mobilized to form lahars. Similarly, an eruption outside the caldera resulting in rapid melting of a thick snowpack might produce lahars. Such lahars would be localized in low-lying areas and would tend to be confined to narrow canyons. Hazards from monogenetic volcanoes near Crater Lake include slow-moving lava flows and viscous domes and associated tephra falls, surges, and pyroclastic flows. The 30 -year probability of eruption of a new volcanic vent near Crater Lake is $3 \times 10^{-3}$ to $3 \times 10^{-4}$ (Bacon and others, 1997b).

Three volcano-related events of high consequence are considered to have low probability: (1) A large pyroclastic eruption, such as the one during which the caldera formed or the (smaller) 1991 eruption of Mount Pinatubo, Philippines, is not considered likely for many thousands of years. (2) Sudden gas release from Crater Lake, such as the lethal release of cold $\mathrm{CO}_{2}$ from Lake Nyos, Cameroon, in 1986, would seem to be a possibility. However, natural mixing of deep water with near-surface water in Crater Lake prevents buildup of volcanic $\mathrm{CO}_{2}$ that escapes from the lake floor. (3) Catastrophic draining of Crater Lake is an extremely unlikely event. No known mechanism, short of another large-volume eruption, could either eject most lake water or cause the caldera wall to fail.

The many tectonic faults and historic seismicity indicate that damaging earthquakes can occur in the Crater Lake area in the future. The West Klamath Lake fault zone (WKLFZ), composed of several individual faults having lengths as much as $15 \mathrm{~km}$ and an aggregate length of 50 to $70 \mathrm{~km}$, has been mapped through Crater Lake National Park west of the caldera (Bacon and others, 1997b, 1999; figs. 4 and 5). One of its constituent faults, the Annie Spring fault, passes less than $2 \mathrm{~km}$ west of Rim Village. The lengths of the faults and the measured displacements suggest that the WKLFZ is capable of tectonic earthquakes as large as magnitude 7.25 (M7.25). The recurrence interval of large earthquakes in this fault zone is unknown but probably is between 3,000 and 10,000 years. Local volcanic earthquakes would produce ground motion at Crater Lake, but the likely maximum magnitude of such events is $\sim M 5$, which is far smaller than expected for tectonic earthquakes. Although distant, the potential for the Cascadia subduction zone to generate $M 8-9$ earthquakes means that as much as several minutes of continued shaking could occur at Crater Lake. Should a large mass of rock fall or slide rapidly from the caldera wall into Crater Lake, one or more large waves could be generated. Waves could be many meters high and travel across the lake in as little as 2 minutes, such as from Chaski Bay to the boat landing at Cleetwood Cove.

\section{Location and Access}

Most of Mount Mazama lies within Crater Lake National Park in southern Oregon; its lower flanks are within Rogue 
River and Winema National Forests. Access to the rim of Crater Lake caldera is excellent, by way of paved roads from O.R. 62 and Oregon Route 230 (O.R. 230), but Mazama's flanks within the park, save for Sun and Sand Creek valleys, are generally only reachable by hiking trails. This guide serves for a long 1-day excursion through the park, concentrating on features near the caldera rim road, with additional points of interest that could be visited on a second day. Modern USGS 7.5-minute topographic maps covering Mount Mazama and adjacent areas were published in 1985 at a scale of 1:24,000. Up-to-date information on access, accommodations, and visitor services can be obtained from Crater Lake National Park. The brochure entitled "Crater Lake," which contains an adequate road map of the park, is available at the park entrance booth and visitor centers at Rim Village and park headquarters. July and August are the best months to visit the park. In most years, snow limits access to the caldera rim through June, and early fall storms may interfere with a trip in September. It is wise to contact the park for information on early summer or fall snow conditions and to be prepared for thunderstorms or cold weather at any time; see http://www. nps.gov/crla/index.htm.

\section{Site Descriptions}

A more detailed eruptive history of Mount Mazama and descriptions of many of the localities noted in this guide can be found in Bacon (1983 and 1986) and in Bacon and Lanphere (2006). The geologic maps and caldera wall panoramas by Bacon (2008) provide context for the guide and information on features not described herein (figs. 5 and 6). Ages of units, given in thousands of years before present (ka), are by K-Ar and ${ }^{40} \mathrm{Ar} /{ }^{39} \mathrm{Ar}$ dates by M.A. Lanphere (Bacon and Lanphere, 2006) unless otherwise indicated; quoted uncetainties are \pm 1 sigma. All $\mathrm{SiO}_{2}$ concentrations are from X-ray fluorescence chemical analyses recalculated volatile free. Rock names are based on $\mathrm{SiO}_{2}$ concentration: basalt $\leq 52$ wt. percent, basaltic andesite 52-57 percent, andesite 57-63 percent, dacite 63-68 percent, and rhyodacite 68-72 percent (fig. 3). Geologic unit names and abbreviations are those used by Bacon and Lanphere (2006) and Bacon (2008). Collecting is prohibited in the park, although collecting permits may be requested in advance from Crater Lake National Park. Climbing or walking on the caldera walls is not allowed except on the Cleetwood trail.

Numbers at left in the main road log are distances in miles from the junction of the road to Crater Lake and O.R. 62. Short logs give notable localities along O.R. 138 between Roseburg, Diamond Lake, and the junction of the north park entrance road; on O.R. 62 between its junction with O.R. 230 on the Rogue River and the start of the main log; sites on O.R. 230; on O.R. 62 between Fort Klamath and the start of the main log; and on U.S. 97 near Chemult. We draw upon Marli B. Miller's comprehensive "Roadside Geology of Oregon, 2014" for geology outside the vicinity of Crater Lake National Park. This book is a valuable complement to this and other IAVCEI field trip guides for Oregon.

Latitude and longitude for each location are given in decimal degrees referenced to North American Datum 83 (NAD83), which is virtually equivalent to the World Geodetic System 84 (WGS84) datum in common use by current global positioning system (GPS) devices. Numbered stops in the main road log (fig. 2) are selected to illustrate highlights of Mount Mazama geology.

\section{Main Road Log}

Numbers at left are distances in miles from starting point. Numbers in bold at the end of each entry are the distance in miles to the next entry.

Junction of O.R. 62 and road to Crater Lake (lat $42.8658^{\circ} \mathrm{N}$., long $122.1691^{\circ} \mathrm{W}$.). Roadcut west of junction exposes three Pleistocene olivine basaltic andesite flows in a scarp of the Annie Spring normal fault. The top flow is basaltic andesite west of Arant Point (unit baw, probably about $200 \mathrm{ka}$ ) and the lower two flows are basaltic andesite west of Mazama Campground (unit bcw, early or middle Pleistocene). Arant Point, $0.8 \mathrm{mi}(1.3 \mathrm{~km})$ to the south, is the intrusive core of a former cinder cone atop a comagmatic tuya (andesite of Arant Point, unit at; $297 \pm 12 \mathrm{ka}$ ) built during MIS 8 and cut by the same Annie Spring fault (Bacon and others, 1999).

Drive south (toward Klamath Falls) on O.R. 62. 1.1

1.1 Stop 1. Turnout with view of Annie Creek canyon (lat $42.8587^{\circ}$ N., long $122.1544^{\circ}$ W.; fig. 12). Excellent exposure of valley-filling medial-facies pumiceous ignimbrite of ring-vent phase of climactic eruption (Bacon, 1983, 2008; Druitt and Bacon, 1986, 1989; Bacon and Druitt, 1988; fig. 5, unit cd). The date of the climactic eruption continues to be refined; for now, we suggest $\sim 7,700$ calendar yr B.P. Lower half of $\sim 100 \mathrm{~m}$ section is silicic ignimbrite dominated by rhyodacite pumice clasts with 70.4 percent $\mathrm{SiO}_{2}$. Most of upper half is mixed ignimbrite containing 20 to 80 percent silicic pumice, the rest is andesitic to basaltic scoria of 51 to 61 percent $\mathrm{SiO}_{2}$. The uppermost $\sim 10 \mathrm{~m}$ are mafic ignimbrite with less than 20 percent silicic pumice. Scoriae in valley-filling ignimbrite generally are hornblende and plagioclase phyric; olivine- and clinopyroxene-rich clasts occur near the top of the section. Most scoriae apparently are cumulates. The color change of the matrix of the deposit from buff below to gray above reflects increasing emplacement temperature upward, as much as its composition. Note 
the bleached zone of fumarolic alteration beneath the uppermost $1 \mathrm{~m}$ of fine ash. Erosion-resistant pinnacles and coarse columnar joints (near falls) result from vapor-phase induration. Entire section was deposited without significant breaks, as no sharp grain size breaks are evident. Note, however, rusty stained lithic-rich horizon near lower part of deposit. Garfield and Applegate peaks on the caldera rim are visible on the skyline to the north. Lithic breccia (unit cb, Bacon, 2008) high on the slopes of these peaks and in the adjacent valleys forms the proximal facies of the same eruptive unit exposed here at Annie Creek.

Return to junction of O.R. 62 and road to Crater Lake. 1.1

0.0 Junction of O.R. 62 and road to Crater Lake (lat $42.8658^{\circ} \mathrm{N}$., long $122.1691^{\circ} \mathrm{W}$.). Turn right on road to Crater Lake and stop at Crater Lake National Park entrance station. Proceed to Stop 2. 4.0

4.0 Stop 2. Crater Lake National Park Headquarters, Steel Visitor Center, and lithic breccia locality. Information, literature, and restrooms are available at the visitor center (lat $42.8963^{\circ} \mathrm{N}$., long $122.1335^{\circ} \mathrm{W}$.) between 8 a.m. and 5 p.m. Cliffs to east of parking lot are mainly andesite of Applegate Peak (unit aa; 270 260 ka here) above outcrops of dacite of Chaski Bay (unit db; $354 \pm 4$ ka near here); highest lava flow, hornblende andesite of Garfield Peak (unit ag; 224 $\pm 9 \mathrm{ka}$ ), has notably columnar base. To examine lithic breccia (fig. 13), walk $0.1 \mathrm{mi}(0.2 \mathrm{~km})$ north of headquarters on developed path and shoulder of road to first roadcut on right (lat $42.8983^{\circ}$ N., long $122.1328^{\circ}$ W.). Roadcut

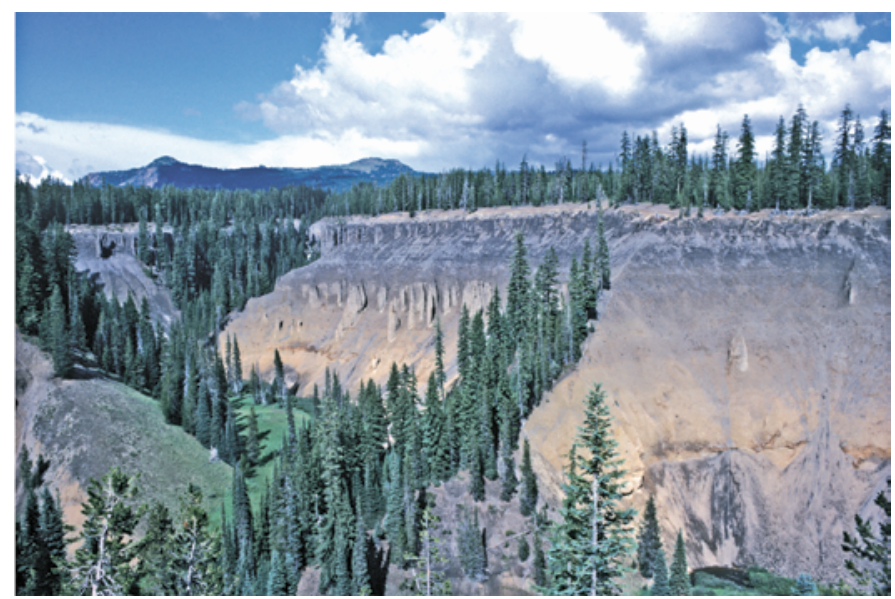

Figure 12. View to the east-northeast showing ignimbrite of the climactic eruption at Godfrey Glen (left center), viewed from turnout on 0.R. 62 (Bacon, 2008). High points on the skyline are Garfield Peak (left) and Applegate Peak (right) at the top of the south wall of Crater Lake caldera. exposes coarse lithic breccia of proximal facies of ring-vent-phase pyroclastic-flow deposits of the climactic eruption (Bacon, 1983; Druitt and Bacon, 1986; Bacon, 2008, unit cb). Similar material underlies floor of Munson Valley in this vicinity. Lithic breccia also occurs on summits of all nearby peaks, both in the lee of or upslope from obstacles, and locally on the upper slopes of Mount Mazama (fig. 14). Most clasts here are variably altered andesite from deep within or beneath Mount Mazama. Systematic variation in clast lithology around the caldera is evidence for multiple vents during this part of the eruption (Bacon, 1983; Suzuki-Kamata and others, 1993). Note rounding of these clasts resulting from thermally induced spalling of corners. Some clasts are highly altered friable andesite; rare clasts are partially fused granitoids. Deposit is clast supported and subtly imbricated. Matrix here contains hornblende andesite pumice. At some localities, juvenile material zones from rhyodacite pumice at the base upward to mafic scoria. Roadcut is in a bedform near the east side of Munson Valley. Longitudinal and transverse bedforms are common in the lithic breccia. 0.5

Return to headquarters and vehicles. Turn left to head north on West Rim Drive. 0.8

4.5 Second roadcut north of headquarters (lat $42.9028^{\circ} \mathrm{N}$., long $122.1344^{\circ} \mathrm{W}$.) on road to caldera rim exposes dacitic fragmental deposit (Stop 3; dacite of Munson Valley, unit $\mathrm{dv}$ ), overlain by about $1 \mathrm{~m}$ of airfall pumice believed to have been erupted from the Llao Rock center (Stop 4), overlain by lithic breccia. Lava outcrops between here and Stop 3 are dacite of Chaski Bay (unit db; 350 ka).

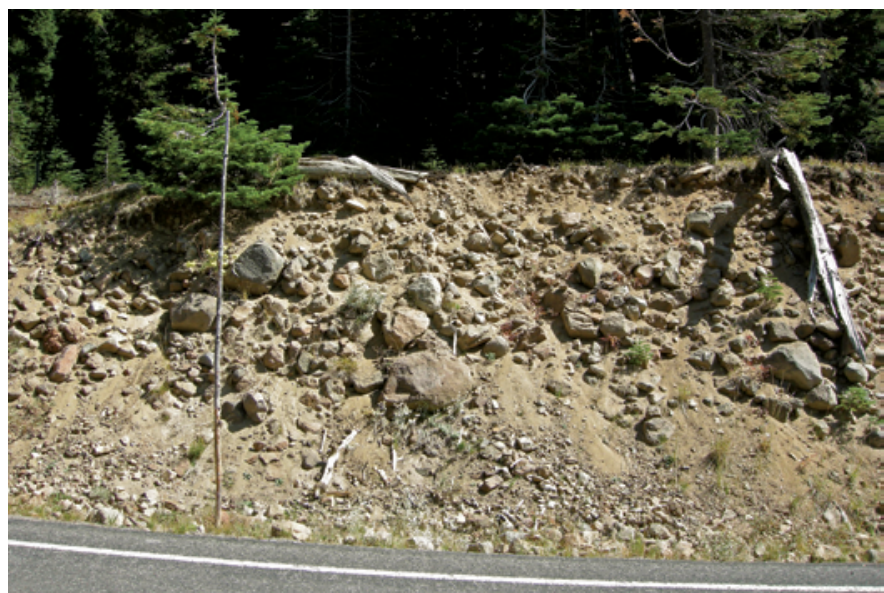

Figure 13. View to the east showing roadcut in lithic breccia bedform (unit cb) near Crater Lake National Park Headquarters, Steel Visitor Center. 
Figure 14. Schematic sketch showing areal distribution of lithic breccia and pumiceous ignimbrite and their relations to surface topography (modified after Druitt and Bacon, 1986, fig. 2). Underlying pumice-fall deposit and Wineglass Welded Tuff, not everywhere present, omitted for clarity.

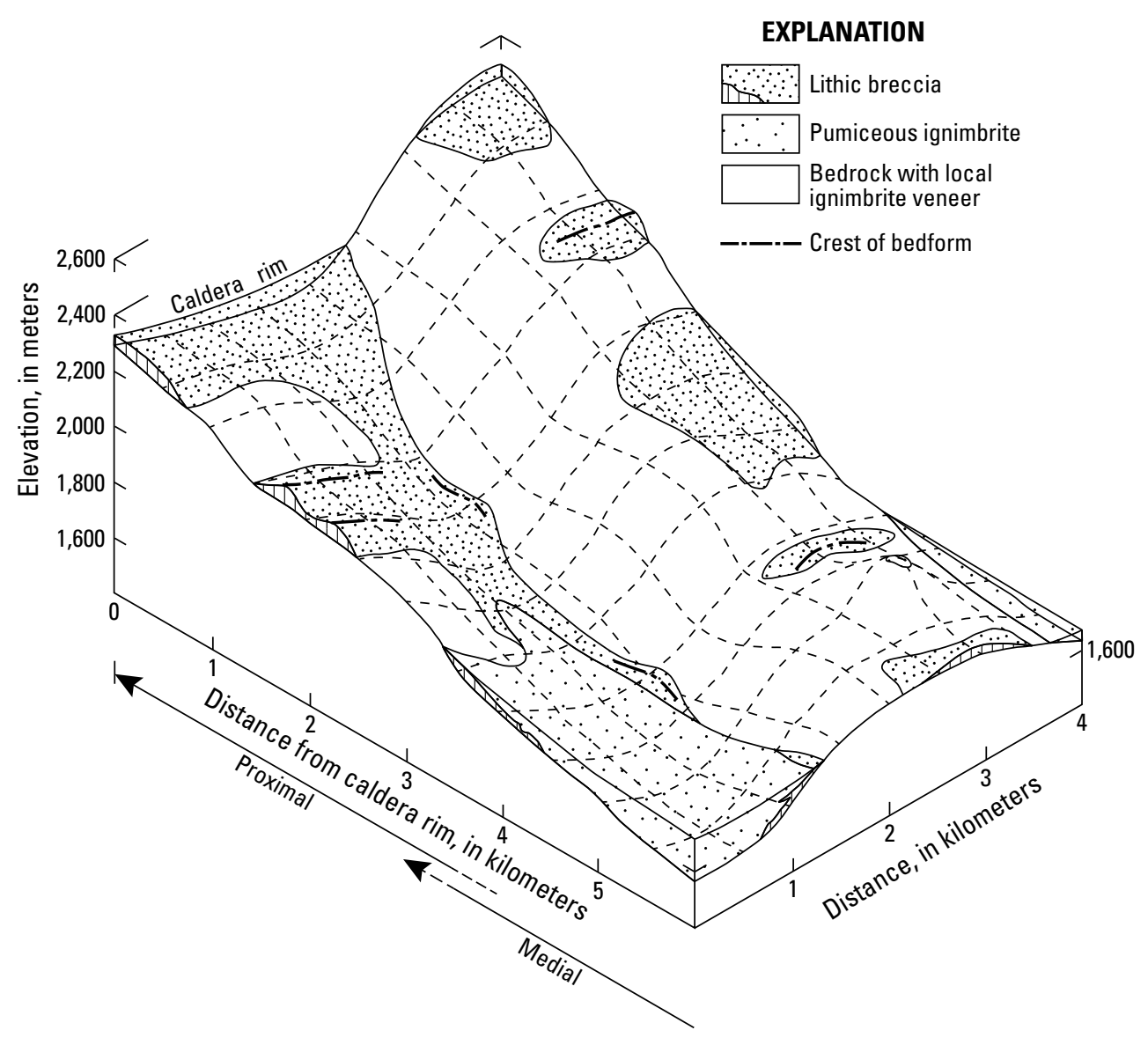

VERTICAL EXAGGERATION ×4
5.3 Stop 3. Dacite of Munson Valley (units dv and dvb; Bacon, 2008; 63.5-69.5 percent $\mathrm{SiO}_{2}$, most $<65$ percent $\mathrm{SiO}_{2}$; about $35 \mathrm{ka}$ ). Long, straight roadcut with turnout on south (left) side (lat $42.9042^{\circ} \mathrm{N}$., long $122.1407^{\circ} \mathrm{W}$.) immediately after hairpin turn from northeast to southwest exposes two subunits of dacitic fragmental rocks (fig. 15). Eastern subunit (unit dv) is monolithologic debris-flow or avalanche deposit that apparently records collapse of dome(s) southwest of Mount Mazama summit. Similar material is in the tree-covered swale high on Garfield Peak visible to the east. Western subunit (unit dvb) apparently is coeval or younger and contains the same dacite, altered dacite, and dense prismatically jointed dacite and pumiceous dacite blocks believed to represent the final pulse of magma responsible for dome(s) destruction (Bacon, 1985, fig. 7). The western subunit is thought to be a lithic pyroclastic-flow (block-and-ash flow) deposit. The dacite contains undercooled enclaves of andesite magma (60 percent $\mathrm{SiO}_{2}$; Bacon, 1986, figs. 7 and 8, table 3). The dacite of Munson Valley is constrained at $\sim 35 \mathrm{ka}$, because it is lightly glaciated and shares an unusual paleomagnetic direction with basaltic andesite of Red Cone, dated at
$35 \pm 4 \mathrm{ka}$. Lava outcrops between here and Stop 4 are andesite of Applegate Peak (unit aa; 260 ka here). Continue west on West Rim Drive. 1.5

Stop 4. Rim Village, view of caldera (lat $42.9121^{\circ} \mathrm{N}$., long $122.1465^{\circ} \mathrm{W}$.). Morning light is good for viewing north and west caldera walls (fig. 1); afternoon for east walls. The locus of andesitic volcanism moved from east to west during construction of Mount Mazama.

Imposing cliff on north caldera wall is Llao Rock

(fig. 16), the vent-filling rhyodacite flow and associated pumice fall deposit dated at 7,015 $\pm 45{ }^{14} \mathrm{C}$ yr B.P. (Bacon, 1983) or approximately 7,800-7,900 calendar yr B.P. This compositionally zoned silicic eruption (70-72 percent $\mathrm{SiO}_{2}$ ) preceded the climactic eruption by about 100-200 years, as indicated by radiocarbon ages (Bacon, 1983) and paleomagnetic secular variation (D.E. Champion, written commun., 1985). The walls below Llao Rock consist of andesite and dacite flows and minor dacite tephra. Several eroded surfaces are present. Lava at lake level here is $\sim 150 \mathrm{ka}$. Sheetlike thin flows here and elsewhere in the walls consist of agglutinated spatter topped by rubble. Such fountain-fed lavas grade from bomb beds and agglutinate near source, 

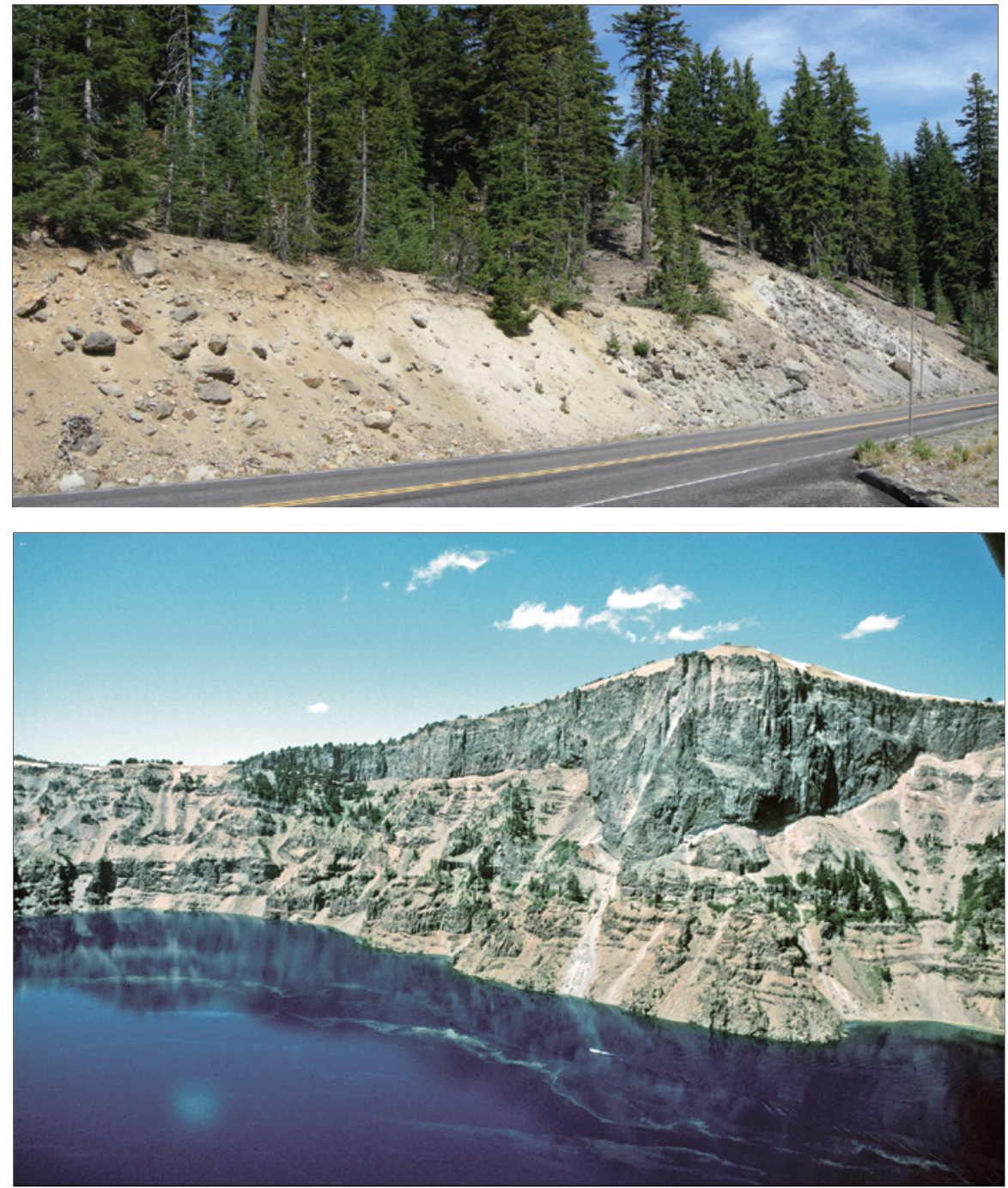

Figure 15. View to the north showing roadcut in dacite of Munson Valley fragmental deposits at Stop 3.

Figure 16. View to the northwest showing the great cliff at Llao Rock that dominates this aerial view and slices into the Holocene rhyodacite lava (Bacon, 2008, unit rh) that filled and overflowed the explosion crater formed in the early stages of the Llao Rock eruption. Climactic pumice fall (unit $\mathrm{cp}$ ) rests on the craggy top of the lava flow but was stripped from the flow's lower flanks by pyroclastic flows of the ring-vent phase of the climactic eruption. Exposed in the caldera wall below Llao Rock are several lava and pyroclastic units ranging in age from unit all ( 170-140 ka) to unit asb (43 \pm 6 ka here). The broad shield volcano (lowest one third of wall), composed of units all and alu, and the thick wedge of unit am (left) are clearly visible in the photograph (Bacon, 2008). Compare with figures $6 D$ and $6 E$.

to streaky lava flows with thick rubbly tops, to distal homogeneous lava with relatively thinner rubble zones. Eye-shaped cliff to east of Llao Rock is rhyodacite of Steel Bay (unit re, 71.6 percent $\mathrm{SiO}_{2}$ ), believed to be one of the earliest products of the climactic magma chamber, emplaced $\sim 27 \mathrm{ka}$. This dome and its cousins, Grouse Hill and Redcloud Cliff, are considered to be $\sim 27 \mathrm{ka}$ by correlation of tephra at Redcloud Cliff with the Trego Hot Springs tephra layer (Benson and others, 1997) and measurements of paleomagnetic secular variation (D.E. Champion, written commun., 1983). East of Llao Rock are Pumice Point and Cleetwood Cove. Cliffs at the rim at Cleetwood Cove are rhyodacite of the Cleetwood flow, which is identical in composition (volatile-free) to the climactic pumice and was still hot when caldera collapsed. Dark lava descending to water level there is the "backflow," which oozed into the caldera following collapse (Bacon, 1983).

West of Llao Rock are Devils Backbone dike (fig. 17), Hillman Peak, and The Watchman (fig. 18).
Gray vegetated slope just below rim south of Devils Backbone marks lithic pyroclastic-flow (block-andash flow) deposit (Bacon, 2008, unit dvb) correlated with that of Stop 3. Devils Backbone fed andesite lava flows (unit ad; probably between 50 and $40 \mathrm{ka}$ ), one of which flowed $11 \mathrm{~km}$ down the west slope of Mount Mazama. Hillman Peak and the wall below consist of pyroxene andesite (unit aww; $70 \pm 4 \mathrm{ka}$ ), overlain by hornblende basaltic andesite (unit bh; $73 \pm 6 \mathrm{ka}$ ), capped by pyroxene andesite with prominent augite and blocky plagioclase (unit ah; $61 \pm 8 \mathrm{ka}$ ). The Watchman dacite flow (unit dwf) is $50 \pm 3 \mathrm{ka}$ and was featured by Williams in his monograph (1942). In the southwest wall are lavas as old as $\sim 300 \mathrm{ka}$, a glaciated surface overlain by dacite of The Watchman nonwelded ignimbrite (unit dwp) that weathers orange, and, at the top, some of the youngest andesite flows of Mount Mazama (units atw and als; 50 ka).

Wizard Island is the tip of a thick pile of postcaldera andesite (unit aw) that was erupted while the lake was 
Figure 17. View to the northwest showing the two segments of the Devils Backbone dike that cut all four lava units visible: lower andesite below Llao Rock (unit all; $150 \pm 9$ ka here), andesite of Merriam Point (unit am; $131 \pm 18 \mathrm{ka}$ ), andesite of the west wall (unit aww; $70 \pm 4 \mathrm{ka}$ ), and andesite south of The Watchman (unit atw, the lava cliff on the caldera rim to right of the upper dike segment; $62 \pm 7$ ka here). Lava flows correlated with the Devils Backbone dike (unit ad; 50-40 ka) extend as far as $11 \mathrm{~km}$ west of the caldera rim. Highest slope to left of left dike segment is underlain by dacite of Munson Valley pyroclastic flow deposit (unit dvb; 35 ka). Photograph from Bacon (2008). Compare with figure $6 C$.

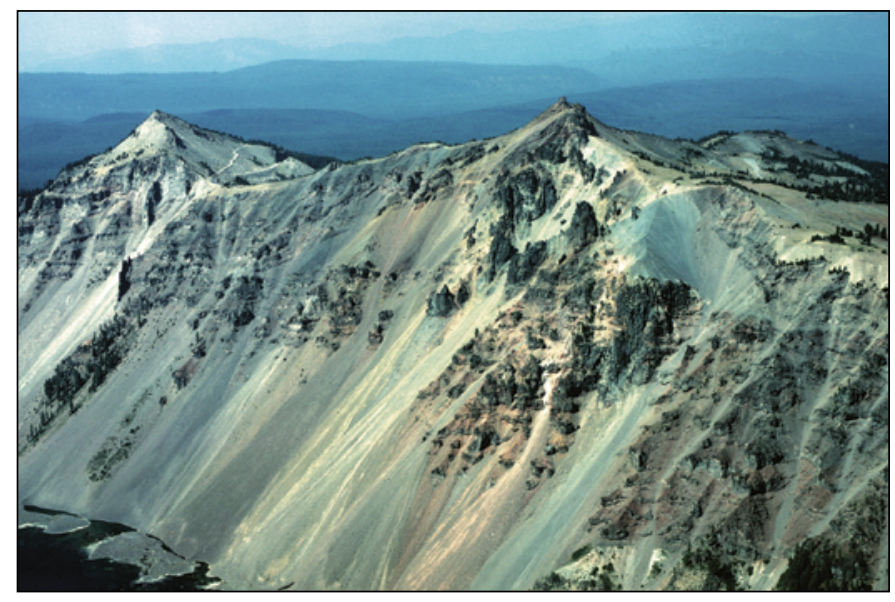

Figure 18. Aerial view to the southwest showing The Watchman (left) and Hillman Peak (right) from opposite Devils Backbone. Light-colored exposure at bottom right is pyroclastic flow deposit (unit dsbp) correlated with dacite of Steel Bay (unit dsb; $116 \pm 5 \mathrm{ka}$ ). Thick package of many lava flows is andesite of the west wall (unit aww; $70 \pm 4$ ka). Gray scree slopes above unit aww lavas are near-vent fall deposit of hornblende basaltic andesite of Hillman Peak (unit bhp) on either side of crags composed of lithified breccia (unit bhp) and intrusive rock (Bacon, 2008, unit bhi; $73 \pm 6 \mathrm{ka}$ ). Andesite of Hillman Peak (unit ah; $61 \pm 8 \mathrm{ka}$ ) forms the summit of its namesake. The Watchman is a glaciated horn sculpted from a thick dacite lava flow (unit dwf; $50 \pm 3 \mathrm{ka}$ ) whose feeder dike forms sail-like outcrops on the caldera wall. Slope above unit aww lava at caldera rim on extreme right is supported by dacite of Munson Valley pyroclastic flow deposit (Bacon, 2008, unit dvb; generalized unit dv in fig. $6 ; \sim 35 \mathrm{ka}$ ). Photograph from Bacon (2008). Compare with figures $6 B$ and $6 C$.

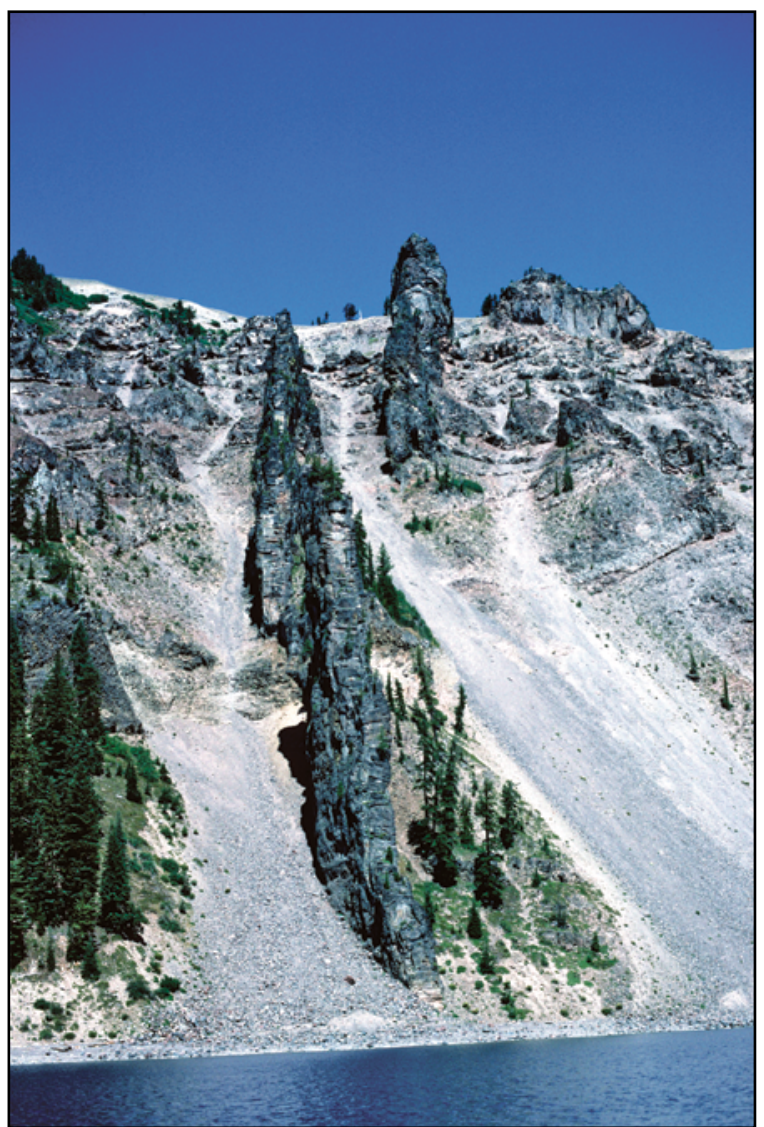

filling to $\sim 75 \mathrm{~m}$ lower than its present level, probably within $\sim 500$ yr of caldera collapse (Bacon and others, 2002; Nathenson and others, 2007; fig. 19). The youngest known volcanic product of Mount Mazama, a small subaqueous rhyodacite dome east-northeast of Wizard Island (unit r; 71.5 percent $\mathrm{SiO}_{2}$ ), reaches within $27 \mathrm{~m}$ of the lake surface and was emplaced $\sim 4,800$ calendar yr B.P. (Bacon and others, 2002).

Partly Melted Granodiorite Block (lat 42.90962 N., long $122.14185^{\circ} \mathrm{W}$.) To examine a large block of partly melted granodiorite (fig. 20), walk east from Rim Village to the parking area for Crater Lake Lodge. This locality may be reached also by driving on the road to the lodge, but parking there is limited. About $60 \mathrm{ft}(20 \mathrm{~m})$ northwest of the Crater Lake Lodge parking area, and where a paved road leads south to a dormitory for employees, is a large $(\sim 2 \mathrm{~m})$ partly melted granodiorite block on the south side of the main road. The dark matrix of the block is rhyolitic glass. Parts of the breadcrusted surface remain. A smaller breadcrusted block lies at the east base of the large one (fig. 20). Similar granodiorite blocks (Bacon, 1992) have yielded zircon dated by ion microprobe uraniumthorium (U-Th) disequilibrium geochronology at various times in the late Pleistocene (Bacon and Lowenstern, 2005). The blocks were ejected during the 


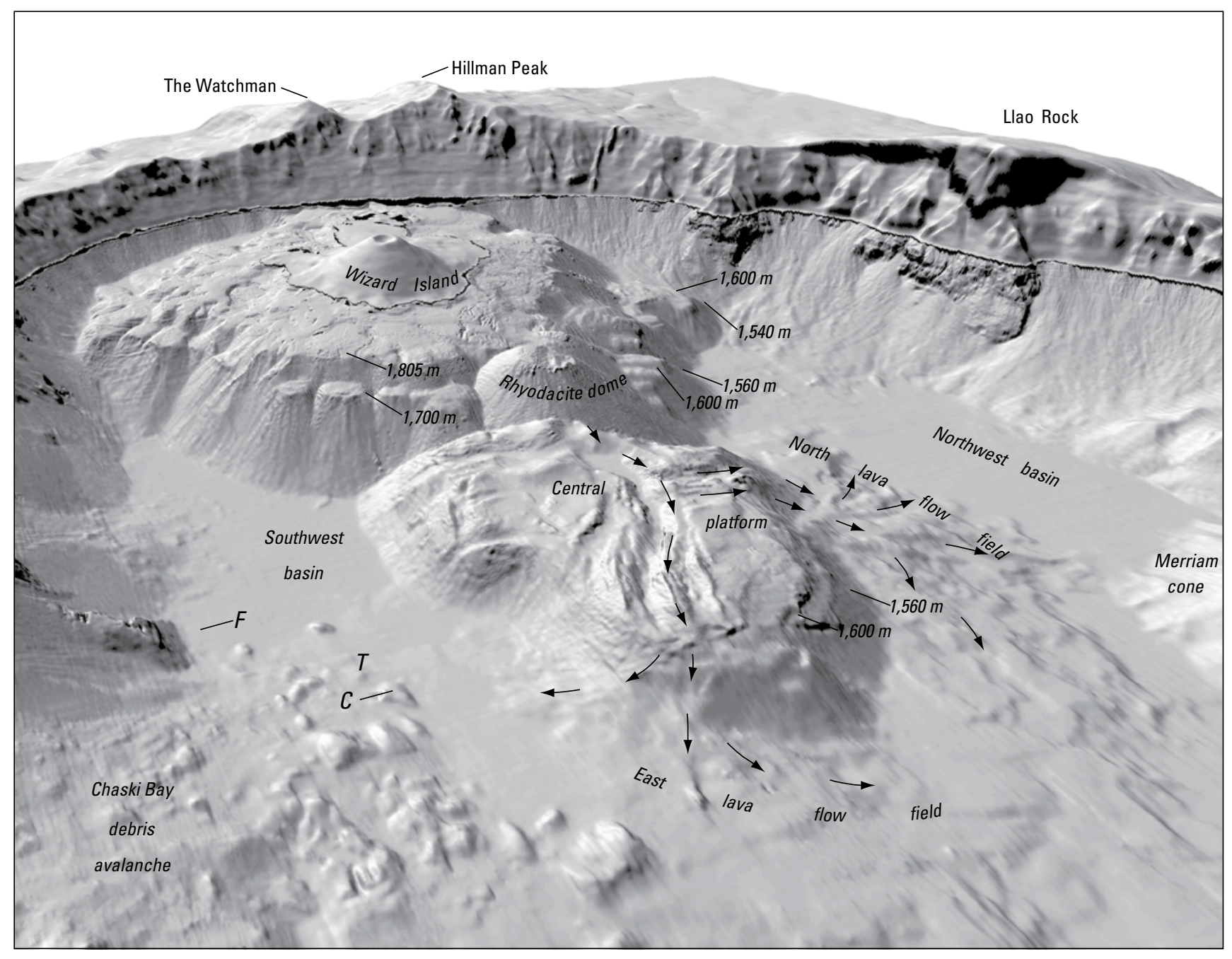

Figure 19. Perspective underwater view of Wizard Island and central platform volcanoes derived from multibeam sonar bathymetry and U.S. Geological Survey 10-meter digital elevation model (DEM) (after Bacon and others, 2002, fig. 4). The Wizard Island and central platform edifices are composed of lava delta sequences that record past levels of Crater Lake. Labeled elevations mark passage zones where subaerial lava entered the lake at indicated elevations and fragmented. Lava flowing in prominent channels on the central platform (filled arrows) cascaded down the edifice and fed subaqueous lava fields. Crater-like depression $(C)$ on south side of block in Chaski Bay debrisavalanche deposit may be a collapse pit or hydrothermal explosion crater. Thermal area characterized by bacterial mats ( $T$ ) was discovered in 1988 while using the submersible Deep Rover (Dymond and Collier, 1989). Steep face of deep bedrock outcrop (F) may be remnant footwall of ring-fracture system along which cauldron block subsided during climactic eruption of Mount Mazama. No vertical exaggeration.

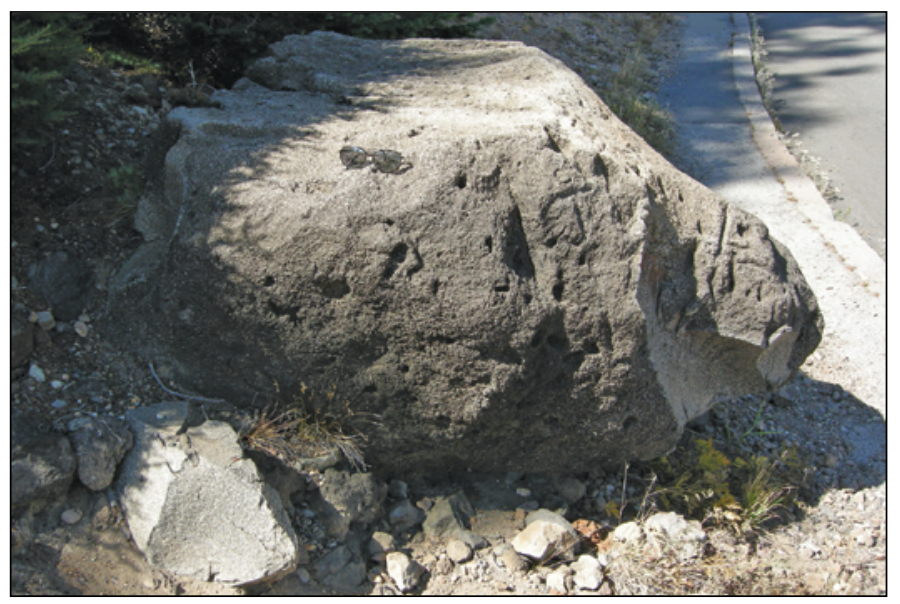

Figure 20. Photograph showing two partly melted granodiorite blocks at Crater Lake Lodge. 
climactic eruption and are present all around Mount Mazama. They represent dacitic and related Mazama magmas that froze a few kilometers below the surface and were remelted to varying degrees to as much as 50 percent by conducted heat from the climactic magma chamber. Minerals in the blocks record subsolidus exchange of oxygen with meteoric hydrothermal fluids prior to reheating (Bacon and others, 1989; Ankney and others, 2017). By providing a source of fusible material otherwise geochemically indistinguishable from erupted magmas, they are the "smoking gun" for the origin of low- ${ }^{18} \mathrm{O}$ silicic magmas.

Return to West Rim Drive and turn right (northwest).

8.9 Stop 5. Andesite flows. Convenient turnout on west side of road (lat $42.9319^{\circ} \mathrm{N}$., long $122.1706^{\circ} \mathrm{W}$.) across from cliff in andesite lava. Beware of falling rock. The two units here have similar silicic andesite compositions but different textures. Younger flow shows glassy brecciated base grading into subtle columns, then upward into platy joints that parallel flow base (andesite of Lightning Spring, unit als; $\sim 50 \mathrm{ka}$ ). Platy zone grades up into coarsely blocky jointed interior. Original rubbly top has been removed by glaciation. In some flows, a second set of platy joints forms steeply dipping sheets high in the flow where this set dominates. Plagioclase phenocrysts in this flow have a distinctive seriate texture. Older flow (andesite south of The Watchman, unit atw; $50 \mathrm{ka}$ ) has a texture more typical of Mazama andesites with plagioclase, augite (green), hypersthene (brown), and titanomagnetite phenocrysts, common glomerocrystic clots, and sparse enclaves. Olivine (yellow) is a common minor constituent of many Mazama andesites. 0.4

9.3 Roadcut on northeast side of road (lat $42.9381^{\circ} \mathrm{N}$., long $122.1724^{\circ} \mathrm{W}$.) exposes crudely bedded lithic breccia (unit cb) lying on glaciated surface of dacite of
The Watchman lava (unit dwf; Druitt and Bacon, 1986, fig. 6). Fumarolic alteration shows breccia was deposited hot. Note platy jointing in The Watchman flow between here and Stop 6. 0.5

Stop 6. The Watchman flow. Turnout (lat $42.9405^{\circ}$ N., long $122.1802^{\circ} \mathrm{W}$.) where West Rim Drive heads north across The Watchman dacite flow gives good view to south (fig. 21) to Mount McLaughlin (38 mi; $61 \mathrm{~km}$ ) and Mount Shasta (125 mi; $200 \mathrm{~km})$. Union Peak is the eroded core (unit bui) of a cinder cone atop a basaltic andesite shield (unit bu; $164 \pm 11 \mathrm{ka}$ ) in the middle distance. A rounded hill $2 \mathrm{mi}(3.2 \mathrm{~km})$ south of Stop 6 (unit denp, Bacon, 2008), cut by the down-to-the-east Annie Spring fault (Bacon and others, 1999), is the source of dacite north of Castle Creek lava (unit den; $216 \pm 4 \mathrm{ka}$ ) that flowed at least $10 \mathrm{~km}$ to the west. A remnant of the pumiceous blocky carapace of the dacite flow can be examined and seen in the roadcut to grade down through glassy dacite (both mapped as unit dwv) into devitrified rock (unit dwf). This lava has 67.5 percent $\mathrm{SiO}_{2}$ and contains rare andesitic enclaves (61 percent $\mathrm{SiO}_{2}$ ). Its porphyritic texture and two-pyroxene, plagioclase, and iron-titanium oxide phenocrysts are typical of Mazama dacites. 0.8

10.6 Wizard Island overlook. Parking area (lat $42.9460^{\circ} \mathrm{N}$., long $122.1692^{\circ} \mathrm{W}$.), restrooms, and short walk to caldera view from between The Watchman and Hillman Peak. 0.6

11.2 Stop 7. View to north and Williams Crater. Large turnout on northwest side of road (lat $42.9544^{\circ} \mathrm{N}$., long $122.1735^{\circ} \mathrm{W}$.) gives view of Red Cone (north; unit br; $35 \pm 4 \mathrm{ka}$ ) and Bald Crater (north-northwest; $192 \pm 20 \mathrm{ka}$ ) basaltic andesite cinder cones. In the middle distance, left to right, are Mount Bailey, Diamond Peak (beyond Diamond Lake), and Mount Thielsen (fig. 22). Three Sisters volcanoes may be seen in the far distance on clear days. To reach

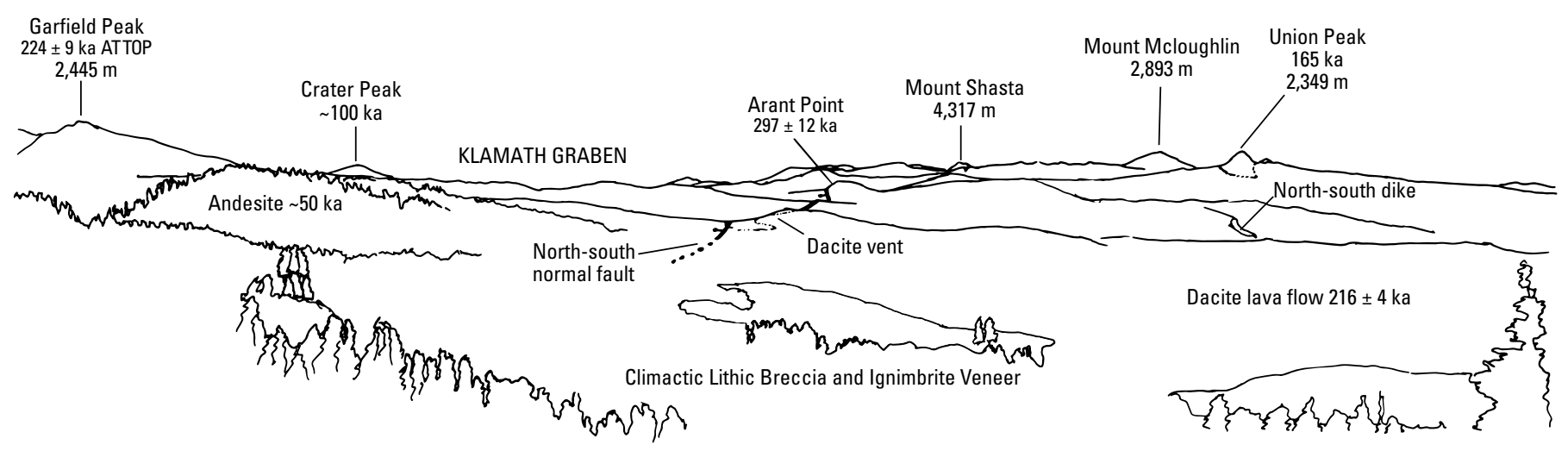

Figure 21. Sketch of view to south from Stop 6 (reproduced from Bacon, 1989). 


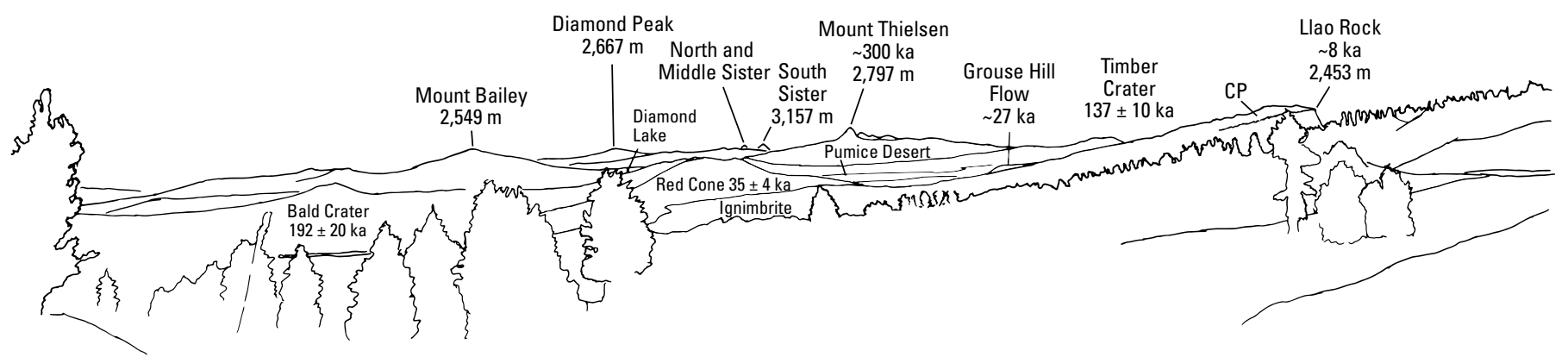

Figure 22. Sketch of view to north from Stop 7 (reproduced from Bacon, 1989). CP is climactic pumice fall (unit cp).

Williams Crater (fig. 23; named after volcanologist Howel Williams; Bacon, 1983, 1990), walk south along West Rim Drive. In the first roadcut, note lithic breccia bleached by fumarolic alteration lying on basaltic lapilli from Williams Crater, which in turn rests on breccia of andesite of Hillman Peak (unit ah; $61 \pm 8 \mathrm{ka}$ ). The andesite lava has distinctive blocky plagioclase phenocrysts, hypersthene, and prominent augite. Just past this roadcut, turn west and walk about $1,300 \mathrm{ft}(400 \mathrm{~m})$ to Williams Crater, avoiding fragile vegetation and noting the small dacite dome (unit mw) immediately south of where you left the road. This dome is the easternmost lava of the Williams Crater complex, which consists of a basaltic andesite flow (unit bw; has silica concentration of basalt owing to ubiquitous gabbro microxenoliths), cinder cone, and three more flows (unit mw) of commingled andesite and dacite with basaltic andesite enclaves. Before reaching Williams Crater, note the arcuate bedform of lithic breccia (unit cb, Bacon, 2008) banked against it. Williams Crater contains bombs cored with angular fragments of commingled andesite-dacite lava, themselves bearing enclaves of the basaltic andesite. Walk to the south side of the cinder cone and visit the

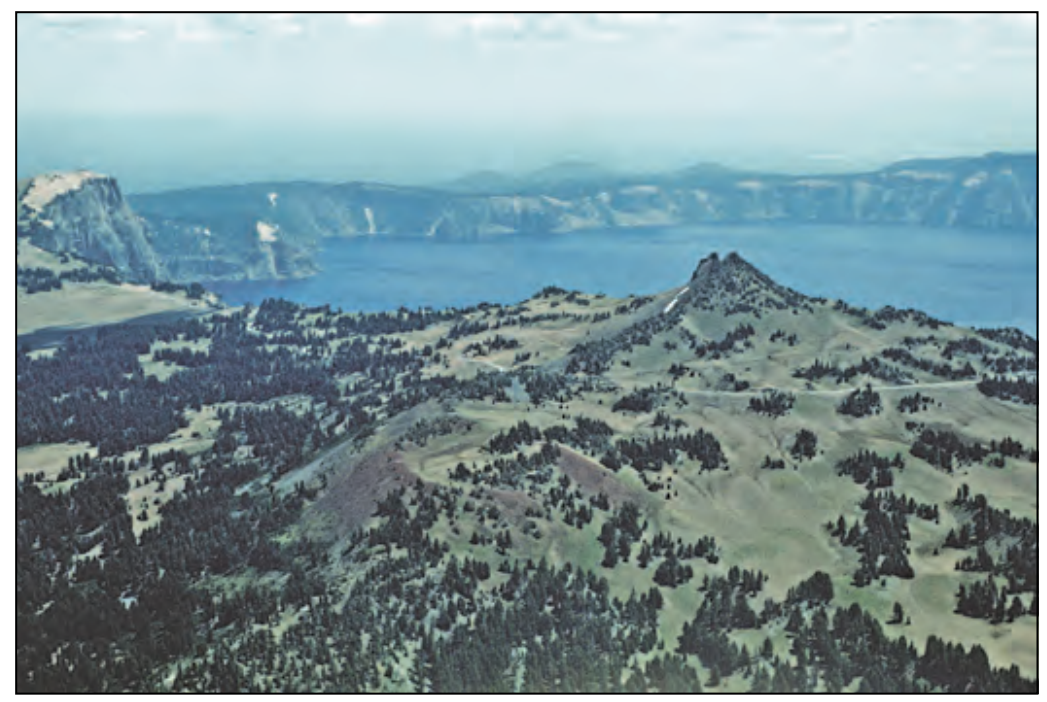

roughly 10-m-high cliff in commingled lava to see a variety of proportions of andesite and dacite. A basaltic andesite dike evidently intersected the margin of a silicic magma reservoir, venting first basaltic andesite, but forcing convective mixing in the reservoir. Basaltic andesite thoroughly mixed with dacite to form hybrid andesite, which then mingled with the dacite, and blobs of basaltic andesite became incorporated in both andesite and dacite. Fragments of the commingled magma were thrown out in the basaltic andesite eruption of the cinder cone. Finally, viscous commingled lava oozed from vents on a trend radial to the present caldera. That all of these events took place rapidly is indicated by paleomagnetic results obtained by D.E. Champion, which show the same direction of thermoremanent magnetization for all units of Williams Crater. The dacite is chemically most similar to that of the fragmental deposits in Munson Valley (units dv and dvb, Stop 3); tephra from Williams Crater lies on the deposit south of Devils Backbone noted at Stop 4. The lavas and tephra of Williams Crater are thus $\sim 35 \mathrm{ka}$.

Return to West Rim Drive and continue driving northeast. $\mathbf{1 . 2}$

Figure 23. Aerial view to the east-northeast over Williams Crater cinder cone and Hillman Peak on the west rim of Crater Lake caldera. Mingled basaltic andesite and dacite lava (unit mw; forested) issued from west (left) base of cinder cone, crater, and a tiny dome by West Rim Drive. Treeless ground is mainly underlain by fine-grained lithicand crystal-rich ignimbrite and proximal lithic breccia of the climactic eruption. Buff-colored slope on top of rhyodacite flow of Llao Rock (unit rh), upper left, is the pumice fall deposit of the climactic eruption. Three rounded, forested hills beyond caldera rim in center of view are pre-Mazama rhyodacite domes, left to right, Bear Butte, Lookout Butte, and Scout Hill (unit rpb). Photograph from Bacon (2008). 
12.4 Stop 8. Hornblende basaltic andesite, lithic breccia, and cumulate blocks. Below turnout on east side of road (lat $42.9638^{\circ} \mathrm{N}$., long $122.1543^{\circ} \mathrm{W}$.) is a glacially striated outcrop of hornblende basaltic andesite of Hillman Peak (unit bh; $73 \pm 6$ ka). Similar rock crops out about $100 \mathrm{ft}(30 \mathrm{~m})$ west of the road. Nearby are mafic blocks in the final veneer deposit of the climactic eruption (unit cu, Bacon, 2008). These are plagioclasepyroxene cumulates with variable amounts of olivine or poikilitic hornblende (Druitt and Bacon, 1989). The veneer locally mantles lithic breccia (unit cb, Bacon, 2008), which to the west occurs in bedforms with clasts to $5 \mathrm{~m}$ (Druitt and Bacon, 1986, fig. 10). Llao Rock can be seen well from this point. The bedded climactic pumice fall present near its summit was eroded from its flanks by ring-vent-phase pyroclastic flows. The dark streak truncating pumice fall beds on Llao Rock is scoria-bearing ignimbrite veneer. $\mathbf{0 . 3}$

12.7 Turn right at junction of East Rim Drive and north entrance road (lat $42.9660^{\circ} \mathrm{N}$., long $122.1516^{\circ} \mathrm{W}$.). At caldera rim, lithic breccia (unit cb) grades down into pumiceous ignimbrite (unit cf), which grades down into a small outcrop of the Wineglass Welded Tuff (unit cw; Stop 12; units of Bacon, 2008) that lies on bedded fall deposits. 0.3

\subsection{Stop 9. Llao Rock Vitrophyre and Proximal}

Ignimbrite. Park in large turnout on west side of road (lat $42.9697^{\circ}$ N., long $122.1500^{\circ} \mathrm{W}$.) past big roadcut in dark vitrophyric lava. Ignimbrite veneer (unit cu) lies on lithic breccia (unit cb) at north end of roadcut. About $20 \mathrm{~cm}$ of pink vitric ash, the co-ignimbrite (or co-pyroclastic-flow) ash-cloud deposit caps the veneer. The climactic pumice fall (unit cp) and most of the original blocky pumiceous carapace of the Llao Rock flow (unit rhc) have been removed by the pyroclastic flows. Pumiceous rhyodacite grades down into vitrophyre (unit rhv; units of Bacon, 2008), which becomes lithophysal and spherulitic deeper into the flow south along the roadcut. Note abundant andesitic enclaves (magmatic inclusions, Bacon, 1986, figs. 5 and 6, table 2). $\mathbf{1 . 4}$

14.4, Views northeast to Grouse Hill (70-71 percent $\mathrm{SiO}_{2}$ ).

14.8 Grouse Hill lava is chemically and mineralogically similar to the rhyodacites of Steel Bay and Redcloud Cliff (unit re; $\sim 27 \mathrm{ka}$ ), the most chemically evolved of the preclimactic rhyodacites and all of which carry abundant crystal cargo derived from Pleistocene granodiorite (Bacon and Lowenstern, 2005). Uncommon andesitic enclaves are present in Grouse Hill and Steel Bay domes. The lavas have vitrophyric margins (unit rev, Bacon, 2008) with cube and columnar jointing that resulted from contact with glacial ice or meltwater. The Grouse Hill flow evidently was ice bounded. 0.1

14.9 Roadcut in rhyodacite lava of Steel Bay (unit re; lat $42.9812^{\circ} \mathrm{N}$., long $122.1235^{\circ} \mathrm{W}$.). Rock contains plagioclase, hornblende, augite, hypersthene, titanomagnetite, and ilmenite phenocrysts, rare andesitic enclaves. See description of Grouse Hill above. Roadcuts between here and Stop 10 are in andesite of Steel Bay, the youngest remaining precaldera andesite of Mount Mazama (unit asb; $43 \pm 4$ ka). Continue east on East Rim Drive. 1.1

16.0 Stop 10. Pumice Point. Park at long turnout (lat $42.9771^{\circ} \mathrm{N}$., long $122.1057^{\circ} \mathrm{W}$.) and walk about $1,000 \mathrm{ft}(300 \mathrm{~m})$ along old, mostly overgrown road to rim at Pumice Point (fig. 24). Visible on the steep slope below are the following deposits, from base to top

Figure 24. View to the north showing Pumice Point. Lowest cliff is upper unit of andesite below Llao Rock (unit alu; $117 \pm 3 \mathrm{ka}$ ), which rests on glaciated surface of lower unit of andesite below Llao Rock (unit all; $122 \pm 20$ ka here; obscured by talus). Middle cliff is dacite of Steel Bay (unit dsb). Highest cliff, present on right of pumice slope, is andesite of Pumice Point (unit apu) that fills small paleovalley cut in fall deposit of dacite of Pumice Castle (unit dcp) resting on glaciated surface of unit $\mathrm{dsb}$. The higher, broader part of the pumice slope consists of $6 \mathrm{~m}$ of pumice fall from the nearby Llao Rock vent (unit rhp) overlain by $31 \mathrm{~m}$ of climactic pumice fall and interbedded nonwelded ignimbrite (unit $\mathrm{cp}$ ), in turn truncated by $1 \mathrm{~m}$ of Wineglass Welded Tuff (unit cw; barely visible at top of pumice) that grades up into $2 \mathrm{~m}$ of proximal-facies, lithic-rich climactic ignimbrite (unit $c b$; unit identifiers and photograph from Bacon, 2008). Compare with figures $6 F$ and $6 G$.

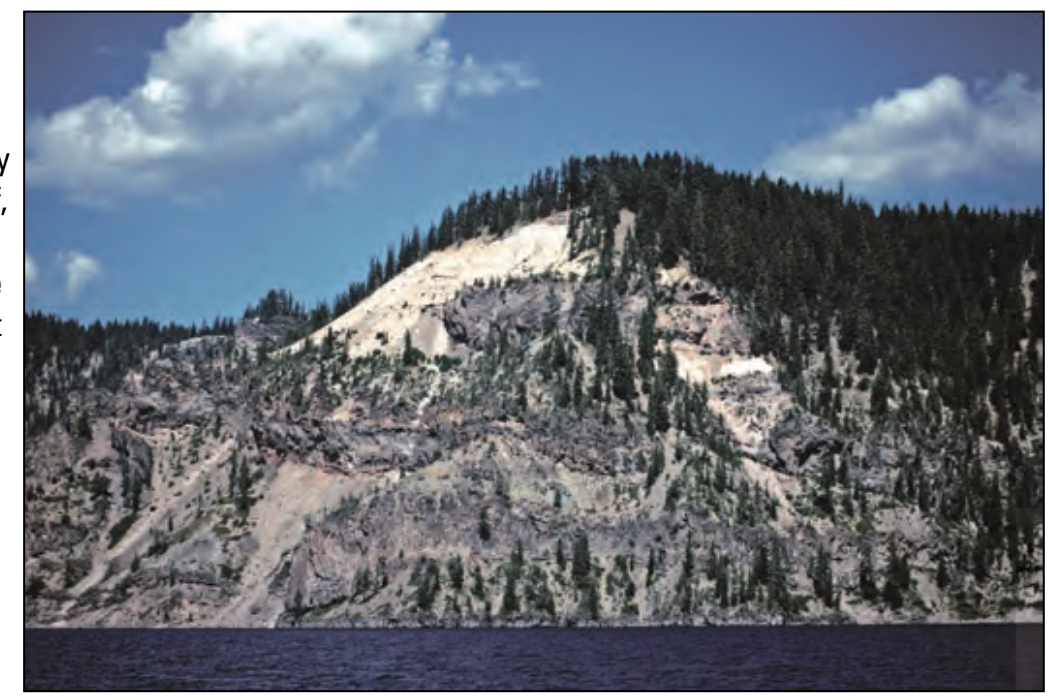


(units of Bacon, 2008): (1) Faintly orange dacite airfall pumice most likely erupted from a vent near the east wall of the caldera at Pumice Castle (unit dcp, $71 \pm 5 \mathrm{ka}$; Stop 16) and resting on glaciated dacite of Steel Bay (unit dsb, 116 $\pm 5 \mathrm{ka}$ ); (2) a glaciated lava flow of andesite of Pumice Point (unit apu; 47 $\pm 20 \mathrm{ka}$ ) filling an erosional depression in the dacite airfall pumice; (3) $6 \mathrm{~m}$ of light-gray Llao Rock pumice fall (unit rhp) forming a gentle slope above the lava; (4) $31 \mathrm{~m}$ of climactic pumice fall (unit cp), pinkish, in well-defined beds with nonwelded pyroclastic-flow interbeds, supporting the steep slope; (5) orange incipiently welded Wineglass Welded Tuff (unit cw) grading upward into (6) lithic breccia (unit cb); (7) ignimbrite veneer (unit cu); (8) ash-cloud deposit, as at Stop 9; (9) crystal and lithic ash, presumably re-ejected from the caldera by phreatic explosions following collapse; and (10) a few feet of wind-reworked material forming a small dune at the caldera rim. Near the base of unit cp is a meter-thick, reddish, incipiently welded bed of climactic airfall pumice that contains rare hornblende andesite scoria and partially fused granodiorite blocks. Continue east on East Rim Drive. 0.3

16.3 Picnic area and restroom on north side of road (lat $42.9783^{\circ} \mathrm{N}$., long $122.1004^{\circ} \mathrm{W}$.).

Continue east on East Rim Drive. 0.9

17.2 Parking lot for trail to lake and tour boats (lat $42.9798^{\circ} \mathrm{N}$., long $122.0832^{\circ} \mathrm{W}$.). Lake tour takes 2 hours, with optional stop at Wizard Island. Highly recommended for a second day. See http:/www.craterlakelodges.com/ activities/volcano-boat-cruises/ or inquire at Visitor Center or Crater Lake Lodge for current schedule and fee. Allow at least 20 minutes to descend and 30 minutes to hike out of caldera. Trail has good exposures of partly welded Wineglass Welded Tuff just below start and cuts before lowest switchback showing climactic airfall, lithic-rich Cleetwood airfall, and Llao Rock airfall lying on LGM (MIS 2) till. Lava flow below till is silicic andesite (unit abl; $110 \pm 10 \mathrm{ka}$ ). Underlying material probably is MIS 6 glacial till that rests on glaciated andesite of the gaging station (unit ags; $189 \pm 3 \mathrm{ka}$ ) immediately west of the boat landing.

17.5 Stop 11. Cleetwood Cove. Park at turnout across road from brick-red pumice (lat $42.9806^{\circ} \mathrm{N}$., long $122.0800^{\circ} \mathrm{W}$.). Below are cliffs in Cleetwood rhyodacite flow and tongue of lava (backflow) that oozed down caldera wall during ring-vent phase of climactic eruption (Bacon, 1983; fig. 25). Cliffs east of cove show internal flow structure of lava. Roadcut (fig. 26) exposes climactic pumice fall (unit cp, Bacon, 2008) lying on Cleetwood flow (unit rh). These units are highly oxidized near their mutual contact. Nowhere but on top of this lava flow is the pumice fall oxidized and sintered. The pumice, which was hot enough when it landed to support steep slopes, fell as a hot blanket on the cooling lava flow, trapping and heating air. This trapped air, and possibly also degassing of the lava, resulted in oxidation. Fumarolic alteration cuts the airfall and overlying lithic breccia (unit cb), showing that the entire climactic eruption took place before the Cleetwood flow cooled completely (Bacon, 1983, fig. 8), less than 100 years and likely much sooner (Kamata and others, 1993). About $600 \mathrm{ft}(180 \mathrm{~m})$ north of here is the first of a series of small rift valleys transverse to the direction of flow, formed as the brittle upper

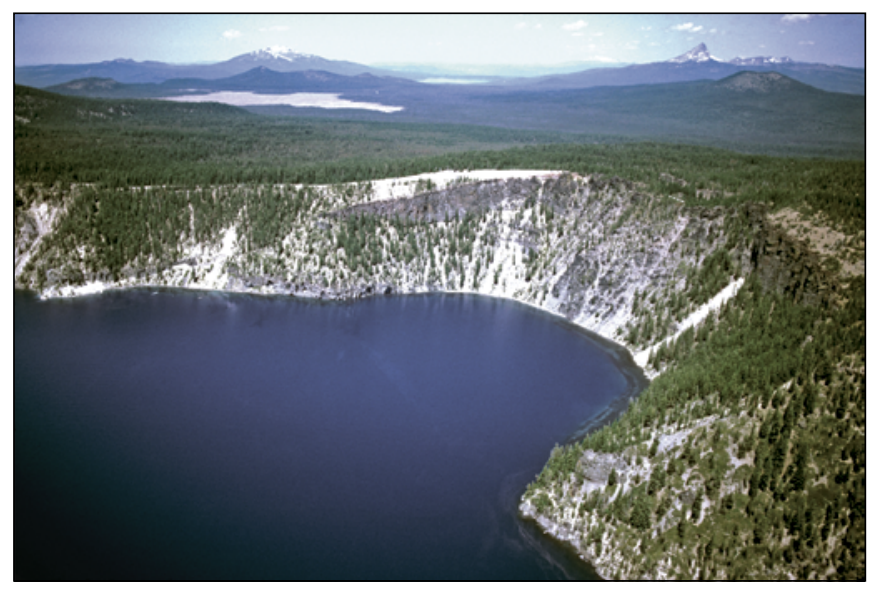

Figure 25. Aerial view to the northwest past Palisade Point showing Cleetwood Cove. Boat landing and lake gage (gaging station) at left, Palisade Point at right. Holocene rhyodacite of the Cleetwood flow (Williams, 1942; unit rh) forms cliff at caldera rim above the arcuate cove; tongue of lava descending to lake's edge is rhyodacite of the Cleetwood flow, remobilized from the pasty interior of the lava flow after the caldera collapsed. Scalloped form of Cleetwood Cove is typical of topographic walls of collapse calderas that enlarge beyond the bounds of a subsiding central block by landsliding during and immediately following a caldera-forming eruption. In the caldera wall beneath the Cleetwood flow are near-vent pumice fall deposits from the onset of the Cleetwood eruption lying on pumice from the Llao Rock vent (collectively unit rhp here, Bacon, 2008), underlain by andesite of Grotto Cove (unit agc; $71 \pm 5 \mathrm{ka}$ ) and andesite of the boat landing (unit abl; $102 \pm 10 \mathrm{ka}$ ). Trail to the boat landing traverses partly welded Wineglass Welded Tuff (unit cw), then descends forested scree slope on thick climactic pumice fall with interbedded nonwelded pyroclastic flow deposits (unit cp), $\sim 1 \mathrm{~m}$ each of Cleetwood and Llao Rock pumice falls, and last glacial maximum (LGM) till before dropping through and along base of the unit abl lava flow. In middle distance beyond caldera rim are the forested northeast portion of the Grouse Hill rhyodacite flow (unit re; 27 ka), treeless Pumice Desert (unit cf), and the forested Timber Crater andesite shield volcano (unit atc; $137 \pm 10 \mathrm{ka}$ ). Mount Bailey (Barnes, 1992) and Mount Thielsen (Sherrod,1991) are to left and right, respectively, of Diamond Lake in the far distance. Photograph from Bacon (2008). Compare with figure $6 G$. 


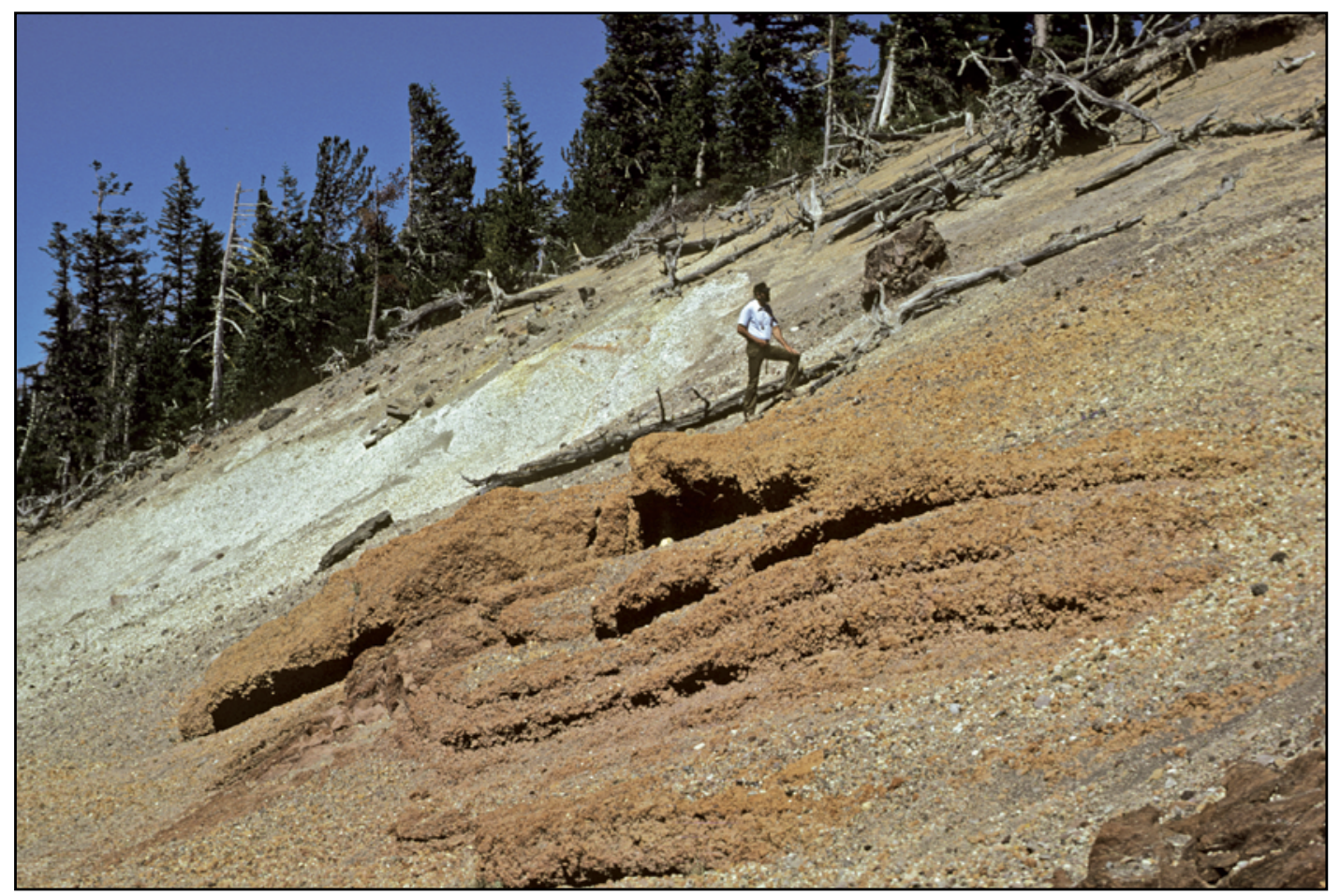

Figure 26. View to northwest showing deposits of the climactic eruption exposed in roadcut on East Rim Drive above Cleetwood Cove. Well-bedded and sorted climactic pumice fall (unit cp, Bacon, 2008) is light gray to white on left but becomes increasingly oxidized, reddish, and compacted (fused) stratigraphically downward where layers drape underlying craggy top of the Cleetwood rhyodacite flow. The oxidation resulted from trapping of air and its reaction at high temperature with iron in the pumice through addition of heat from the lava, which also softened the pumice and caused it to compact. Because the climactic pumice fall deposit is affected in this way only on the surface of the Cleetwood flow, these features are evidence that this lava was still hot at the time of the climactic eruption. The rhyodacite lava crops out below the bedded pumice at the lower left and at the lower right corner of the photograph. Boulders at top of left half of roadcut and the large block to right of person are clasts in lithic breccia (unit cb) that here rests on the pumice fall without intervening Wineglass Welded Tuff. The lithic breccia and accompanying mafic scoria clasts were deposited by pyroclastic flows of the ring-vent phase of the climactic eruption, during collapse of Crater Lake caldera. The channel in unit cp in which the large lithic block occurs may have been cut by the same pyroclastic flows. Pumice lapilli and crystal-rich ash migrating downslope obscure part of the roadcut exposure. Unit identifiers and photograph from Bacon (2008).

surface of the flow broke up while its fluid interior flowed north (presumably in response to seismicity associated with caldera collapse) and south into the caldera. Faults bounding the valleys cut climactic pumice fall and thin Wineglass Welded Tuff. Lithic breccia (unit cb) is banked against the walls of these valleys, showing that caldera collapse began before the ring-vent phase ended (Bacon, 1983; fig. 27), and after deposition of the Wineglass Welded Tuff by a maximum of 9 days (Kamata and others, 1993). Continue east on East Rim Drive. 1.5

19.0 Stop 12. Wineglass Welded Tuff, Palisade flow, and view of caldera walls. Park at the west end of the turnout (lat $42.9678^{\circ} \mathrm{N}$., long $122.0642^{\circ} \mathrm{W}$.) and walk to the caldera rim. You are standing on the Wineglass Welded Tuff (unit cw, Bacon, 2008), the top of which has been scoured away by the ring-vent-phase pyroclastic flows. Note how the Wineglass is thickest in the topographic depression to the east, thins to the west, and is absent from the high point (Roundtop) to the east. The Wineglass consists of as many as four flow units of rhyodacitic ignimbrite that form a single cooling unit. It was deposited by heat-conserving, valley-hugging ash flows that emanated from the collapsed eruption column of the single-vent phase (Bacon, 1983; Kamata and others, 1993). Here, the top of the ignimbrite shows gash fractures parallel to the caldera rim, indicating that, where sufficiently thick, the tuff slumped toward the caldera while still hot and plastic. On the fractured rock 


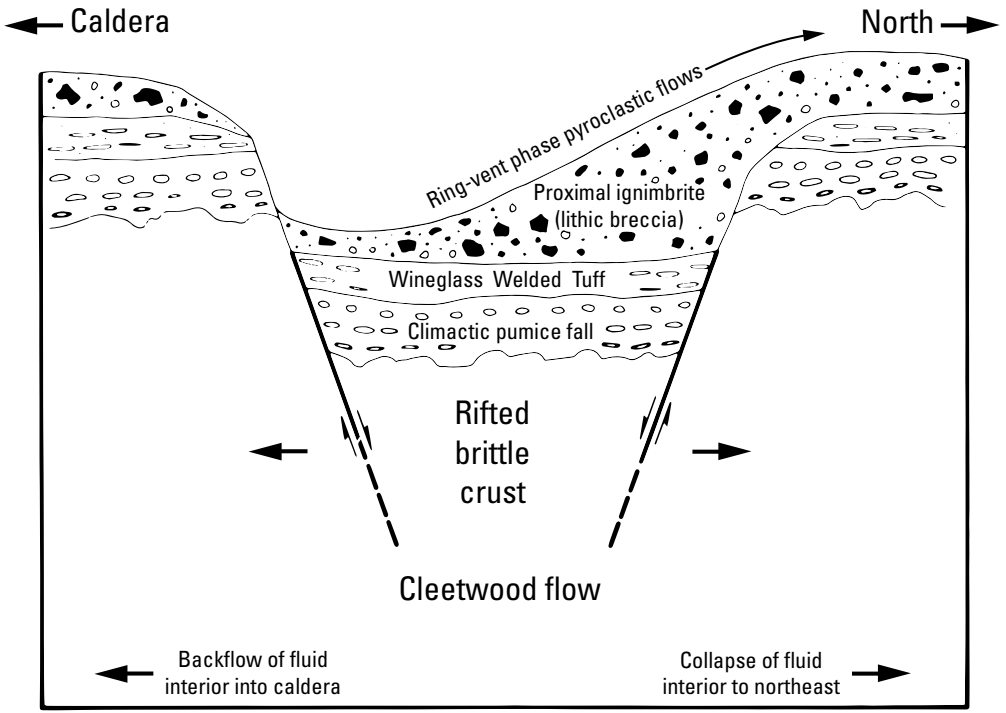

face at Wineglass (Stop 13), fiamme within Wineglass Welded Tuff actually oozed out and down from rock face. This is compelling evidence for the rapidity of events during the climactic eruption. The large pumice slope on the wall south of Skell Head south-southeast of here shows a fine section of Llao Rock (unit rhp) and climactic airfalls (unit cp) overlain by the Wineglass Welded Tuff (unit cw) capped by lithic breccia (unit cb; units from Bacon, 2008; fig. 28; Druitt and Bacon, 1986, fig. 5). There, the Wineglass has four distinct flow units, the top one being a vitrophyre. The lithic breccia appears crudely bedded into five units. The lower two contain rhyodacite pumice, the next two hornblende andesite pumice, and the top one mafic scoria, showing that the breccia mimics the stratigraphic order of the zoned valley-filling ignimbrite. Distribution of Wineglass Welded Tuff demonstrates that the single-vent phase of the climactic eruption was sourced north of the summit of Mount Mazama (fig. 29).

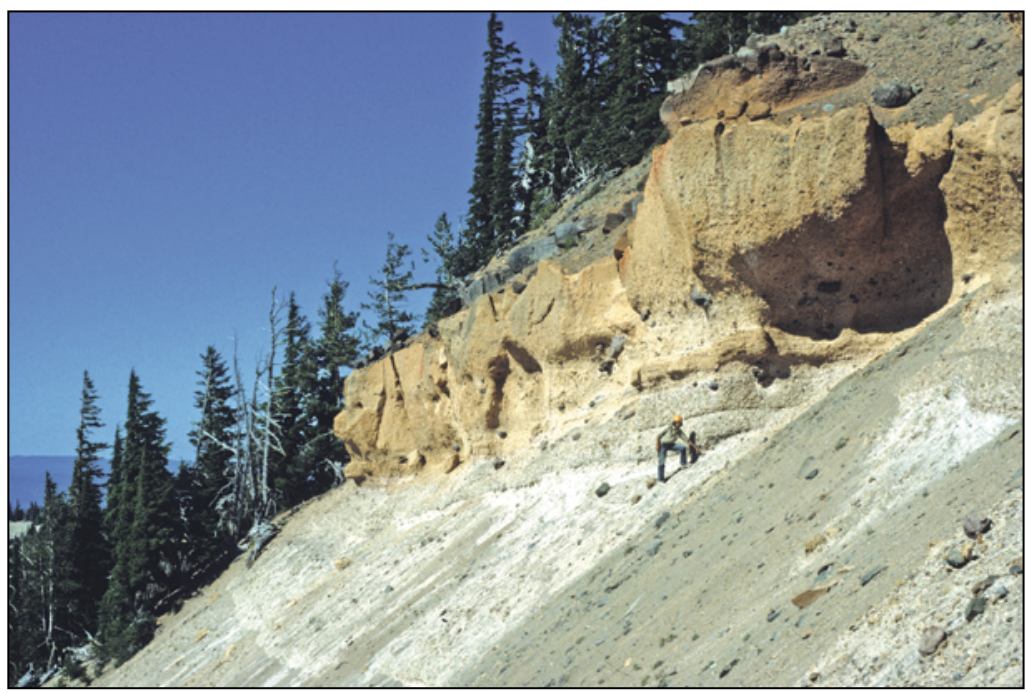

Figure 27. Schematic north-south section through upper part of Cleetwood flow, showing relations between deposits in rift valleys (modified after Bacon, 1983, fig. 12). Overlap of faulted Wineglass Welded Tuff by ring-vent-phase lithic breccia indicates caldera began to collapse after deposition of the Wineglass but before last pyroclastic flows passed over the Cleetwood flow.

The craggy top of the Palisade flow (Williams, 1942; dacite east of Palisade Point, unit dpe; $111 \pm 9$ ka) that forms the cliffs to the west has been glaciated, and the flow occupies an old glacial valley carved against the older silicic andesite of Roundtop (unit ar; $153 \pm 13 \mathrm{ka}$ ), an MIS 6 ice-bounded lava flow, to the east (fig. 30A). Cliffs on the andesite of Roundtop (unit ar) are known as Palisades, not to be confused with the younger Palisade flow of Williams (1942; unit dpe). These two thick flows cap and help to preserve thick unconsolidated glacial and fluvial deposits, largely obscured by talus, that rest upon glaciated andesite of Cloudcap Bay (unit ac) at depths less than $40 \mathrm{~m}$ (fig. 30B; Bacon and others, 2002). Elsewhere, relatively impermeable lava meets the lake shore. This observation, and lack of evidence for prehistoric high stands of Crater Lake, suggests that the lake level is limited by seepage through the sediments, the equivalent of the regulating drain in a bathtub. The lake probably filled to virtually its present level within a

Figure 28. View to the north showing deposits of the climactic eruption above Skell Head, the most complete section exposed on the caldera rim. Climactic pumice fall (unit $c p$ ) forms pinkish-white slope and two prominent beds by and above person. Horizontal boundaries between the four flow units of Wineglass Welded Tuff (unit cw) that make up the orange to brown cliff are marked by recesses and by relatively abundant, dark lithic fragments. The lower three flow units are partly welded and the highest one is densely welded, grading up into black vitrophyre. Above the vitrophyre is a dark-colored slope of debris on proximal lithic-rich climactic ignimbrite (unit cb). Photograph and unit identifiers from Bacon (2008). 

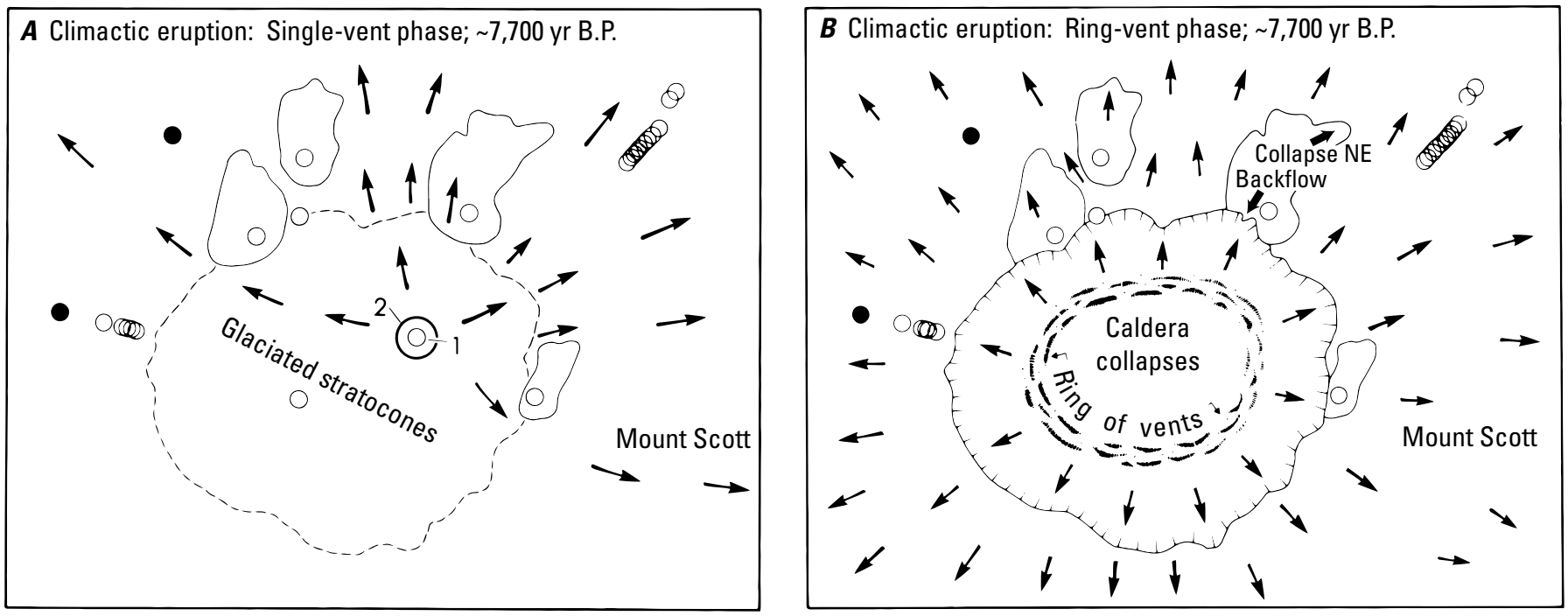

Figure 29. Maps showing pyroclastic flow directions and vent locations for $\sim 35 \mathrm{ka}$ and early Holocene eruptives. Open circles indicate vents for dacitic and rhyodacitic pyroclastics and lavas, filled circles for mafic lavas. $A$, Single-vent phase of climactic eruption inferred vent location. Plinian vent indicated by 1, enlarged vent for Wineglass Welded Tuff by 2 (Bacon 1983; Suzuki-Kamata and others, 1993; Kamata and others, 1993). Arrows show paths of pyroclastic flows that deposited Wineglass Welded Tuff. $B$, Ringvent phase of climactic eruption during which Crater Lake caldera collapsed. Clasts in lithic breccia indicate multiple vents distributed around subsiding block (Bacon, 1983; Suzuki-Kamata and others, 1993). Arrows show direction of movement of pyroclastic flows, which surmounted most topographic barriers. Backflow of Cleetwood flow into caldera and remobilized flow to northeast indicated by wide arrows. Modified from Bacon (1983) figures 6C and 6D.
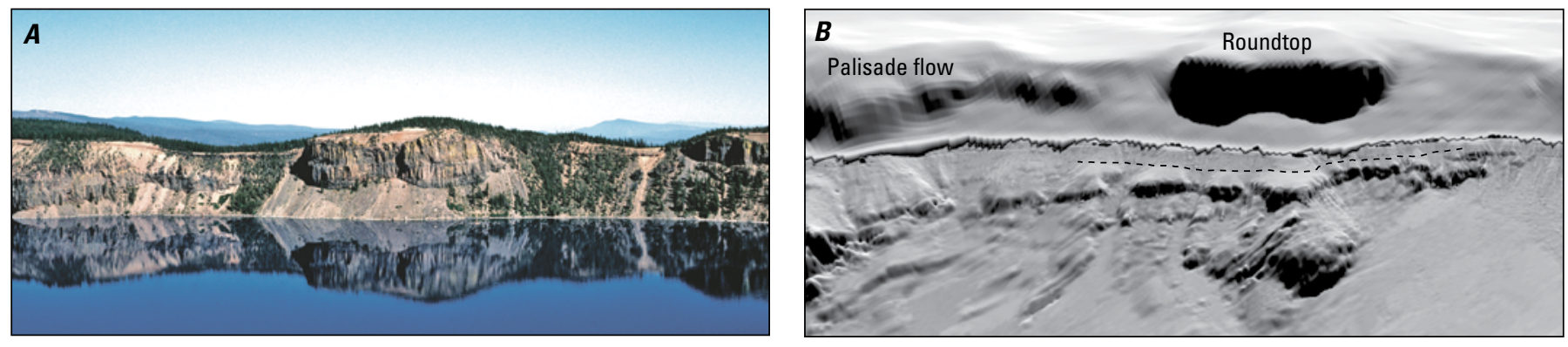

Figure 30. Views to the northeast showing Palisades and Wineglass. A, Aerial view of northeast caldera wall. Palisades, the tall cliff above talus in center, is the ice-bounded lava flow, andesite of Roundtop (unit ar; $159 \pm 13$ ka), which rests on thick glacial till and fluvial deposits largely obscured by talus. To the right of Palisades is the scree chute known as Wineglass. The "bowl" of Wineglass is scree from the three Holocene pumice fall deposits (units rhp and cp, Bacon, 2008) and the overlying Wineglass Welded Tuff and proximal ignimbrite (units cw and cb, respectively); the "stem" of Wineglass crosses subglacial and subaerial andesite of Applegate Peak (unit aa; 270-210 ka) lying on glacial till obscured by talus. The cliff at the caldera rim to the right of Wineglass is ice-bounded andesite of Grotto Cove (unit agc; $74 \pm 10$ ka here). On the left, the Palisade flow (Williams, 1942) forms a cliff that reaches the lakeshore (unit dpe; $119 \pm 9$ ka), fills a glacial paleovalley to the left of Roundtop, and is overlain by glacial till, the Holocene pumice fall deposits, Wineglass Welded Tuff that thickens to the right toward the topographic low point on the rim, and proximal ignimbrite. Visible in the distance 46 kilometers beyond Wineglass is Walker Rim, approximately the northeastern distal limit of climactic ignimbrite. Photo from Bacon (2008). Compare with figure $6 H$. B, Below the lake surface, permeable deposits rest on glaciated andesite of Cloudcap Bay (unit ac); seepage through them has apparently prevented Crater Lake from filling to significantly higher elevation than present $\sim 1,883 \mathrm{~m}$. Appearance of linear ridges inclined to left in lower part of image is an artifact of data processing enhanced by illumination direction. Bathymetry from multibeam sonar; subaerial terrain from U.S. Geological Survey 10-meter digital elevation model (Bacon and others, 2002, fig. 14). No vertical exaggeration. 
few hundred years of caldera collapse and has remained stable, though rising and falling with fluctuations in precipitation and evaporation, ever since (Nathenson and others, 2007).

This is also a good place to see features on the east and south caldera walls. The cliff-forming flows below the rim southeast of here are enclave-bearing silicic andesite of Grotto Cove (unit agc; $71 \pm 5 \mathrm{ka}$ ), the younger of which is the subject of Stop 14. The Redcloud Cliff rhyodacite flow (unit re; 70-71 percent $\mathrm{SiO}_{2}$ ) forms the prominent cliff on the east wall, filling its vent crater and spilling to the north over earlier dacite of Pumice Castle (unit dc; $71 \pm 5 \mathrm{ka}$; fig. $31 \mathrm{~A}$ ). It is compositionally similar to the rhyodacites of Grouse Hill and Steel Bay and is $\sim 27 \mathrm{ka}$. Immediately south and stratigraphically below Redcloud Cliff are Pumice Castle (unit dcp) and related dacite flows (unit dc) described at Stop 16. Below the dacites are a flow of andesite of Applegate Peak (unit aa; here $240 \mathrm{ka}$ ), many thin flows of andesite of Cloudcap Bay (unit ac; probably $290 \mathrm{ka}$ ), fragmental deposits and thick lava flows of dacite of Sentinel Rock (unit dr; 340-300 ka), and andesite of Kerr Notch lavas (unit ak; 340-300 ka). Between Pumice Castle and Kerr Notch, the lower of two beheaded glacial valleys, is Sentinel Rock (fig. 31B; best seen from the west in afternoon light), where thick intracanyon low-silica dacite flows (unit dr) lie on glaciated older andesite (unit ak). Between Kerr and Sun notches is Dutton Cliff (fig. 31C). The oldest rocks exposed on the caldera wall (unit apn; 400 ka) are at water level below Dutton Cliff and comprise the Phantom Cone (Williams, 1942). Stripes on the wall with moderate initial dips highlight yellowish pervasively altered rubbly tops of agglutinated andesite flows (unit apn); their dense interiors, having been less permeable, show little effect of hydrothermal alteration from this distance. Phantom Ship is a small island composed of altered flows of andesite of Phantom Cone. From Dutton Cliff to water level beneath Sun Notch three sets of andesite-dacite flows are exposed. The top is relatively fresh andesite of Applegate Peak (unit aa; 270-210 ka), the middle is altered andesite of Kerr Notch (unit ak; 340-300 ka), and the lowest altered dacite of Chaski Bay (unit db; 380-350 ka) with abundant enclaves. Applegate Peak and Garfield Peak form the summits of the south wall, west of Sun Notch. All are pyroxene andesite and low-silica dacite flows except the top two flows at Garfield Peak, which are hornblende andesite (unit ag; 224 $\pm 9 \mathrm{ka}$ ). Andesite of Applegate Peak made up the bulk of the higher part of the Mount Mazama volcano, built on top and to the west of the extensive andesite of Kerr Notch shield volcano. The altered flows near water level below the big talus slopes between Applegate and Garfield Peaks comprise "Chaski slide" (fig. 31D), a block of caldera wall that failed to completely slide into the caldera. Offshore is a $\sim 5 \mathrm{~km}^{2}$ debris avalanche deposit (fig. $31 E$ ) containing blocks of caldera wall rock as large as $280 \mathrm{~m}$ long that travelled 2-3 km from source (Bacon and others, 2002). West of Garfield Peak is the head of Munson Valley, site of Crater Lake Lodge and Rim Village, which are built on the dacite of Munson Valley debris-flow and lithicpyroclastic-flow deposits of Stop 3 (unit dv; $\sim 35 \mathrm{ka}$ ). Continue east on East Rim Drive. 1.0

20.0 Stop 13. Wineglass. Park at small unpaved turnout on right (lat $42.9625^{\circ} \mathrm{N}$., long $122.0519^{\circ} \mathrm{W}$.) where East Rim Drive meets the caldera rim after traversing the andesite flow of Roundtop. Wineglass refers to the shape of a scree chute below here (fig. 30A). From the southeast side of the valley, excellent exposures of the Wineglass Welded Tuff (unit cw, Bacon, 2008) lying on climactic pumice fall (unit cp) can be seen. The uppermost $1 \mathrm{~m}$ of the fall deposit is oxidized because emplacement of the Wineglass on the warm fall deposit trapped and heated air. Lithic breccia (unit cb) lies on the Wineglass. This is the locality where hot fiamme oozed over the surface of an open fracture (a larger version of those seen from above at Stop 12) before the tuff completely cooled (Bacon, 1983); the block on the caldera side of the fracture has since fallen away, revealing tongues of devitrified glass hanging over the inclined fracture surface (Kamata and others, 1993). Because the caldera must have been present at the time of fracturing, caldera collapse took place shortly after emplacement of the Wineglass; that is, during the ring-vent phase of the climactic eruption (Bacon, 1983). Beneath the scree below, climactic pumice fall lies on Cleetwood airfall pumice, which rests on Llao Rock pumice. Below the airfall units is till containing vitrophyre derived from the andesite of Applegate Peak flow underneath (unit aa; here likely between $\sim 270$ and $\sim 210 \mathrm{ka}$ ). This lava flow displays spectacular radiating columnar joints (fig. 32) that grade into shattered vitrophyre blocks upward into the till. The flow evidently encountered ice (MIS 7.4 or late MIS 8?). Similar features can be seen in many other examples of chilled lava around the caldera.

Continue south on East Rim Drive. 1.0

21.0 Stop 14. Enclaves in andesite. Park on the east side of East Rim Drive in an unpaved turnout (lat $42.9507^{\circ} \mathrm{N}$., long $122.0429^{\circ} \mathrm{W}$.) where the road bends from southeast to south just past a cut in lava on the southwest side of the road. Walk back to this roadcut and observe abundant enclaves (magmatic inclusions) of andesite (60 percent $\mathrm{SiO}_{2}$ ) in silicic andesite (62 percent $\mathrm{SiO}_{2}$; Bacon, 1986). The host is the younger of two compositionally identical flows of andesite of Grotto Cove (unit agc; 71 $\pm 5 \mathrm{ka}$ ). Enclaves larger than about $12 \mathrm{~cm}$ have exceptionally porous (diktytaxitic) cores with denser rinds a few $\mathrm{cm}$ thick. Because of a relatively small initial thermal contrast between porphyritic host and nearly aphyric 

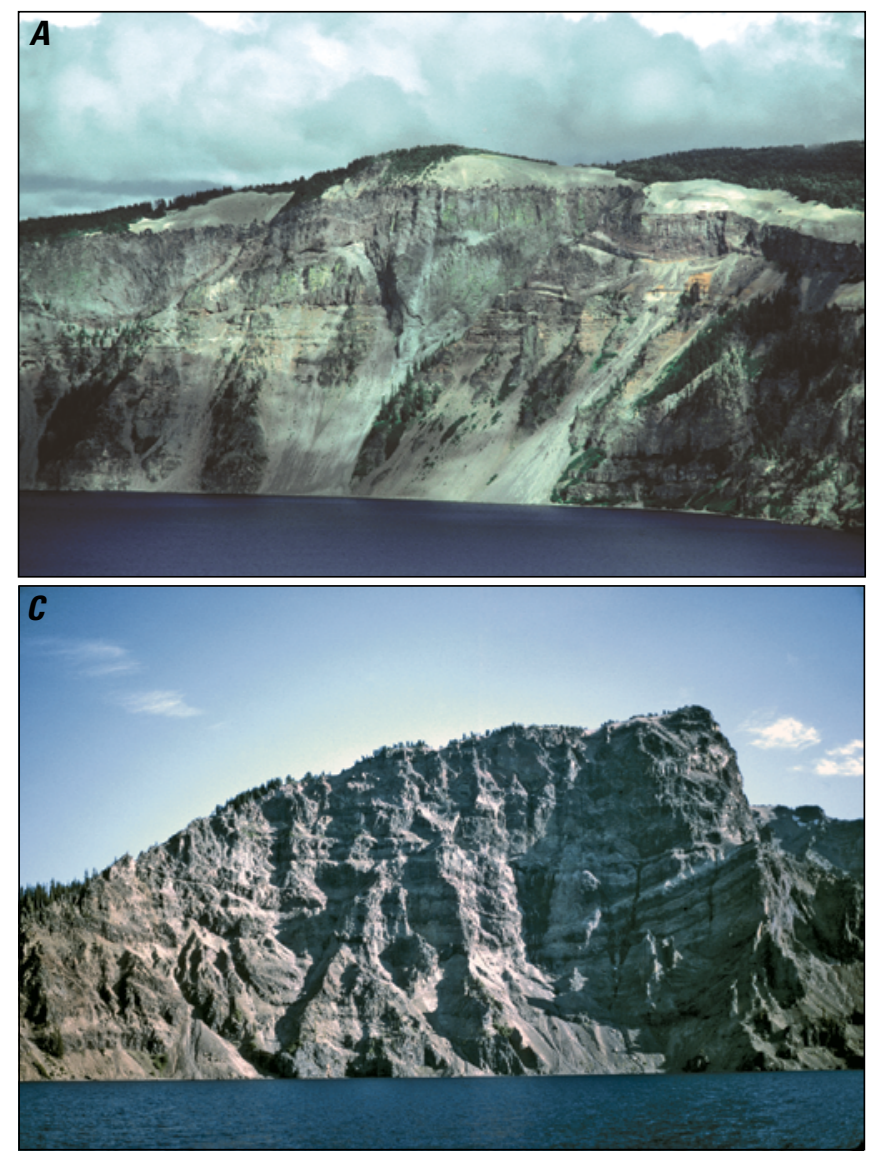

Figure 31. Views showing east and south caldera walls. $A$, Redcloud Cliff dominates this view of the east wall of the caldera. The Redcloud Cliff flow of rhyodacite lava fills the $\mathrm{V}$-shaped crater from which it issued. This flow and its kin (unit re; $27 \mathrm{ka}$ ), the Grouse Hill flow and dome and a small dome above Steel Bay, were emplaced when glacial ice was present. Compare with figure 6l. B, Sentinel Rock from opposite Kerr Notch. Two thick flows of dacite of Sentinel Rock (unit dr; $306 \pm 5$ ka here) fill a glacial valley carved in thinner flows of andesite of Kerr Notch (unit ak; $340 \pm 6$ ka near here). Compare with figure $6 \mathrm{~J}$. C, Nearly $600 \mathrm{~m}$ of relief and 200,000 years of history in caldera wall between Kerr Notch (left) and Dutton Cliff (right). At right, light and dark bands inclined to left are flow-top and pyroclastic breccias and dense lava flow interiors, respectively, of Phantom Cone (Williams, 1942; unit apn; 400 ka). Hydrothermal alteration results in yellowish tan color of breccias owing to oxidation of pyrite. The highest of these bands is dacite of Phantom Cone (unit dpn). Overlying units are dacite of Chaski Bay (unit db), andesite of Kerr Notch (unit ak), and andesite of Applegate Peak (unit aa), all but the last of which are hydrothermally altered to some degree here. Compare with figure $6 \mathrm{~J}$. D, Garfield Peak and Eagle Crags above Chaski Bay. Cliffs at caldera rim are in andesite of Applegate Peak (unit aa; 270-210 ka), with a frosting of andesite of Garfield Peak at top center (unit ag; $224 \pm 9 \mathrm{ka}$ ). Talus rests on flat top of massive slide block that consists of altered lavas of units aa, ak(?), and db(?). Informally known as "Chaski slide," the block was displaced downward from high on the caldera wall. Yellowish tan color results from oxidation of pyrite that is most evident in relatively permeable flow-top breccias. Compare with figure $6 K$. Photographs $A-D$ from Bacon (2008). E, Perspective view of south caldera wall and Chaski Bay debris-avalanche deposit (Bacon and others, 2002, fig. 11). Hummocky topography is formed by blocks derived from caldera wall surrounded by smoother matrix-facies debris. Dashed line indicates eastern limit of Chaski Bay deposit. "Chaski slide" is a slumped block of calderawall lavas. Crater-like depression (C) on south side of block in Chaski Bay debris-avalanche deposit may be a collapse pit or hydrothermal explosion crater. Thermal area characterized by bacterial mats (T) was discovered in 1988 with submersible Deep Rover (Dymond and Collier, 1989). Steep face of deep bedrock outcrop ( $F$ may be remnant footwall of ring-fracture system along which cauldron block subsided during climactic eruption of Mount Mazama. Small rotational slump $(S)$ is present below Sun Notch, a truncated glacial valley. Coarse rockfall $(R)$ is preserved at foot of cliff below Phantom Ship where there is no source of abundant finer clastic material. Prominent scarp below Danger Bay is headwall ( $H$ ) of secondary slide in debris-avalanche deposit. Surrounding terrain from U.S. Geological Survey 10meter digital elevation model. No vertical exaggeration. 


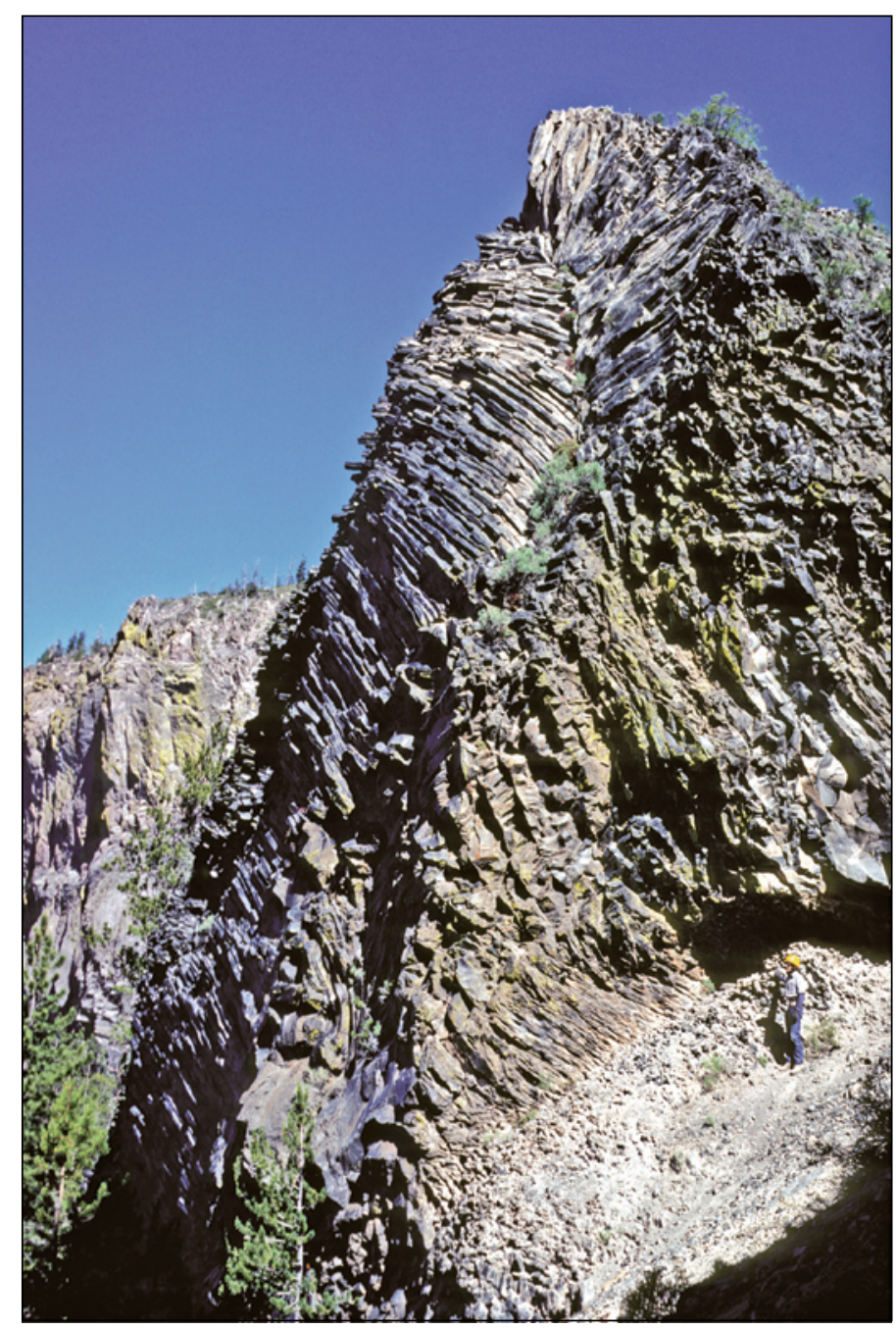

Figure 32. View to the north-northwest showing spectacular columnar joints in andesite of Applegate Peak vitrophyre (unit aa; 270-210 ka) below Wineglass (note person at lower right). Columns formed perpendicular to cooling surface as meltwater penetrated solidifying lava along growing fractures as a result of lava having flowed against or beneath glacial ice. Photograph from Bacon (2008).

enclave magmas, incomplete undercooled crystallization of enclaves resulted in a large fraction of vapor-saturated residual liquid (75 percent $\mathrm{SiO}_{2}$ ). Most of this liquid was expelled from cores of inclusions, which were by then rigid crystal meshes, by gas-driven filter pressing owing to differential vapor pressure between host lava and cores of large inclusions (Bacon, 1986; Sisson and Bacon, 1999). Consequently, cores are more mafic (56 percent $\mathrm{SiO}_{2}$ ) than the original enclave bulk composition. Although the rind texture is not common, andesitic enclaves are abundant in many silicic andesite and dacite flows of Mount Mazama, particularly in the relatively old rocks of Mount Scott and the east and south caldera walls. The roadcut at this stop is high in the holocrystalline interior of the flow; the upper glassy zone

of the flows is preserved locally near their distal ends, where glass-lined segregation vesicles can be seen in enclaves. Enclaves are most abundant near the tops of flows, apparently because tops of flows were erupted later and advanced more rapidly than the underlying lava. Enclaves may have been incorporated into the host from a deeper level in the magma reservoir by forced convection during flow of magma up the eruption conduit.

Return to vehicle and note glaciated exposure of dark-gray vitrophyre to the south, at the north end of the Redcloud Cliff rhyodacite flow (unit re), one of the many features of this lava flow that display chill jointing that resulted from contact with ice. Proceeding south, East Rim Drive meets the caldera rim at Skell Head, then traverses the Redcloud Cliff flow before clinging to cliffs in dacite of Pumice Castle (unit dc) similar to the lava coulee of Scott Bluffs that are prominent to the east and ascending that lava to the flat west of Mount Scott. 2.6

Parking area for Mount Scott Trail (lat $42.9293^{\circ}$ N., long $122.0296^{\circ}$ W.) and view of Mount Scott, highest point in the park $(8,929 \mathrm{ft} ; 2,722 \mathrm{~m})$. Mount Scott consists of the oldest dated lavas of Mount Mazama, about $420 \mathrm{ka}$. This cone is made up of sheets of agglutinated low-silica dacite of Mount Scott (unit ds). Andesitic enclaves are abundant. Glaciation has exposed the core of the volcano. Hydrothermal alteration variably affects these rocks, and these features can be seen readily on the trail to the summit. The summit ridge is capped by climactic pumice fall (unit cp) and lithic breccia (unit cb; units of Bacon, 2008). 0.2

23.8

Turn right on Cloudcap road (lat $42.9290^{\circ} \mathrm{N}$., long $122.0318^{\circ} \mathrm{W}$.).

\section{Stop 15. Rhyodacite lava and pumice, welded} dacite airfall pumice, and view of northeast flank of Mount Mazama. Park on right (north) side of road (lat $42.9359^{\circ}$ N., long $122.0436^{\circ}$ W.). Roadcut on south (left) exposes four airfall pumice deposits and a steeply dipping rib of lava. From east to west, in stratigraphic order, the units (Bacon, 2008) are: (1) buff to orange dacite pumice of Pumice Castle (unit dcp; $71 \pm 5 \mathrm{ka}$ ) with blocky plagioclase and pyroxene; (2) white hornblende rhyodacite pumice with abundant coarse lithic blocks, the proximal airfall (unit rep; 27 ka) for the Redcloud Cliff vent; (3) rhyodacite lava (unit re; $\sim 27 \mathrm{ka}$ ) grading from pumiceous blocks up through vitrophyre into lithophysal and spherulitic rhyodacite, believed to be a glaciated "bathtub ring" of lava left after most of an oversteepened dome slid north to form the Redcloud Cliff flow; (4) Llao Rock airfall (unit rhp; 7,800-7,900 yr B.P.) poorly exposed beneath scree; (5) climactic pumice fall (unit cp; 7,700 yr B.P.) 
supporting a small cliff; and (6) lithic breccia of the ring-vent phase of the climactic eruption (unit cb; $\sim 7,700$ yr B.P.). Walk around the west end of this exposure and up over the lava to a brick-red 2-m cliff east of the roadcut. This is welded airfall dacite of Pumice Castle (unit dcp). In the distance (fig. 33) are Mount Thielsen and tree-covered lateral moraines extending to the east, the Gibraltar-like west-facing scarp of Walker Mountain $31 \mathrm{mi}(50 \mathrm{~km})$ northeast near the town of Chemult (approximate limit of ring-vent-phase ignimbrite, unit $\mathrm{cf}$ ), the toad-back silhouette of Newberry Volcano $68 \mathrm{mi}(109 \mathrm{~km})$ northeast, and the shieldlike form of Yamsay Mountain, a Pliocene volcano $34 \mathrm{mi}(55 \mathrm{~km})$ east. In the middle distance are the andesite shield and cone of Timber Crater to the north (unit atc; $137 \pm 10 \mathrm{ka}$ ) and ignimbrite-floored flats of Klamath Marsh to the east. Closer features are the higher domes of the Sharp Peak group of at least 12 late Pleistocene rhyodacite domes (unit rs; $18 \pm 4 \mathrm{ka}$ ) vented along a radial dike system from the climactic chamber (Bacon and Druitt, 1988), several pre-Mazama rhyodacite domes surmounting thick lava flows (Bear Butte, Lookout Butte, Scout Hill; Nakada and others, 1994; unit rpb, probably $\sim 460-410 \mathrm{ka}$; climactic lithic breccia occurs on the summit of Lookout Butte), cliffs to the north in the silicic andesite of Grotto Cove flow of Stop 14 (unit agc; $71 \pm 5 \mathrm{ka}$ ), cliffs in the Redcloud Cliff flow (unit re), and the dacite flows of Scott Bluffs (unit dc). Continue west on Cloudcap road. $\mathbf{0 . 3}$

24.9 Cloudcap overlook (lat $42.9348^{\circ}$ N., long $122.0485^{\circ} \mathrm{W}$.) with view of caldera. The great face of Redcloud Cliff is below. Cloudcap is the low hill to the southeast, supported by dacite lava of Pumice Castle (unit dc) and covered by climactic deposits. Return to East Rim Drive. Head east to return to East Rim Drive. 1.1

26.0 Turn right onto East Rim Drive (lat $42.9312^{\circ} \mathrm{N}$., long $122.0350^{\circ} \mathrm{W}$.).

27.1 Stop 16. Pumice Castle Overlook. Park at large turnout (lat $42.9273^{\circ} \mathrm{N}$., long $122.0560^{\circ} \mathrm{W}$.) where East Rim
Drive bends to the south. The view of the northeast caldera wall includes the Cleetwood flow (unit rh), Palisade flow (unit dpe), Roundtop flow (unit ar), and Wineglass. Redcloud Cliff (unit re) dominates the east wall in the foreground; the continuation of the cliff north shows a thin line of black vitrophyre, which has subhorizontal columns that indicate flow may have banked against ice in an east-facing cirque headwall, now lost to the caldera. Cliff at caldera rim south of Redcloud Cliff is dacite lava flow (unit dc) lying on comagmatic tephra of Pumice Castle (unit dcp; fig. 34). The latter consists of dacite pumice that is nonwelded at the south end of the exposure but is progressively more densely welded to the north. The weighted mean K-Ar age of dacite of Pumice Castle lavas is $71 \pm 5 \mathrm{ka}$. Just south of Redcloud Cliff, this deposit includes several vitrophyric layers and a stubby lava flow. The top of the airfall has been "fused" by the overlying lava flow. Pumice Castle is the prominent brick red-orange set of towers with resistant welded layers. Below the pumice are a single flow of andesite of Applegate Peak (unit aa; here $\sim 240 \mathrm{ka}$ ) atop a pile of thin flows of andesite of Cloudcap Bay with oxidized rubbly tops (unit ac; probably $\sim 290 \mathrm{ka}$ ) lying on fragmental deposits and thick lava flows of dacite of Sentinel Rock (unit dr; -340-300 ka) above andesite of Kerr Notch lavas (unit ak; 340-300 ka). Numerous dikes (units dc, aa, ac) cut the pre-Pumice Castle rocks.

In the trees just below the caldera rim immediately east of the turnout stone wall is an exposure of partly welded Wineglass Welded Tuff (unit cw), the southeastern-most such outcrop at the rim. Confinement of the Wineglass Welded Tuff to topographic depressions from Merriam Point clockwise to here indicates that the vent for the single-vent phase of the climactic eruption was northeast of the summit(s) of Mount Mazama. Large lithic blocks in the climactic pumice fall (unit cp) above Pumice Castle are consistent with proximity to the vent, which probably was located between here and Cleetwood Cove. Here, as elsewhere, lithic breccia (unit cb) lies on the Wineglass Welded Tuff. Thick lithic breccia also mantles climactic airfall above Redcloud Cliff and the dacite flow above Pumice Castle. The next

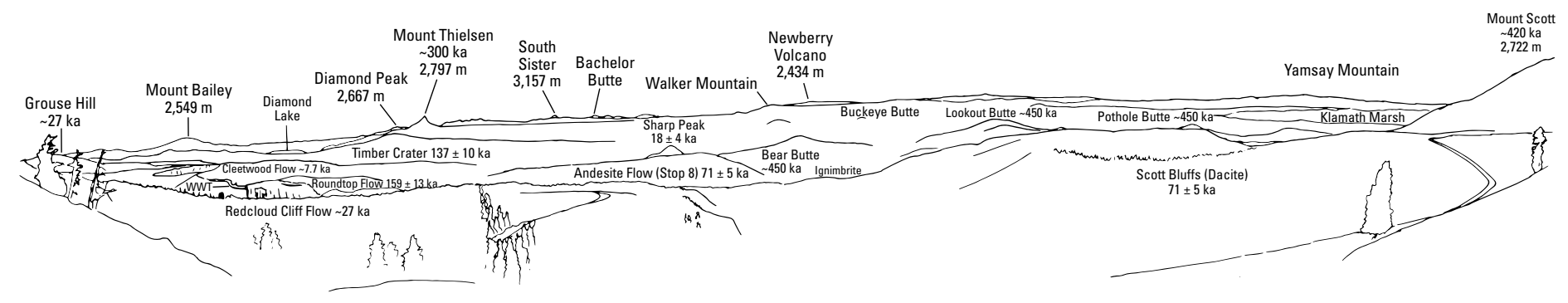

Figure 33. Sketch of view north from Stop 15 (Bacon, 1989). WWT is Wineglass Welded Tuff. 


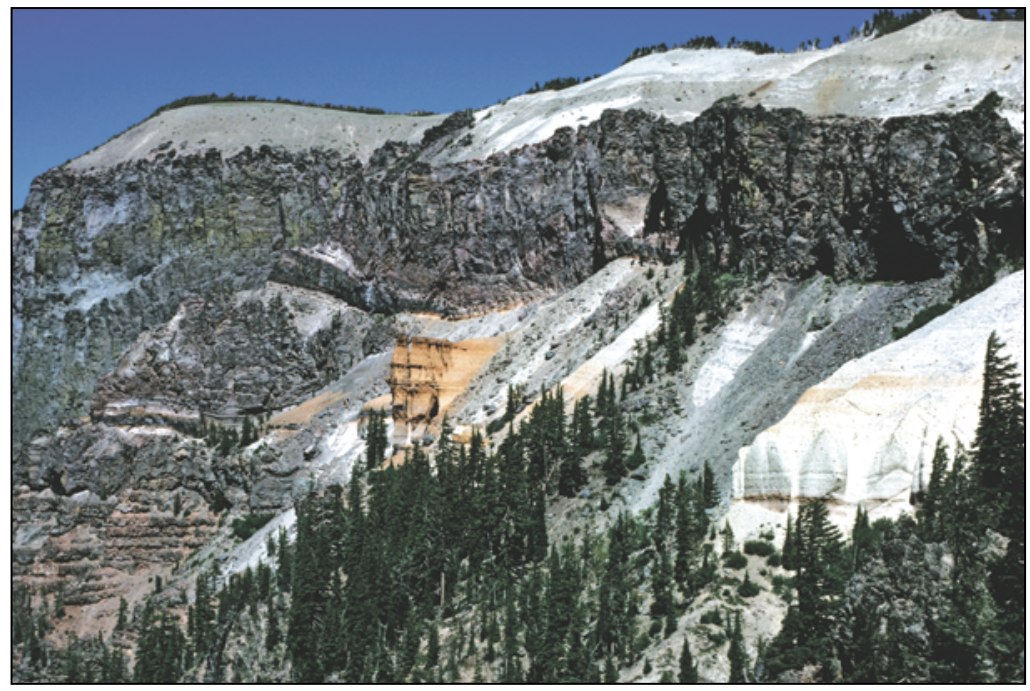

two turnouts provide good views of the south caldera walls (see Stop 12). Lava exposures after road leaves caldera rim and descends to Kerr Notch are andesite of Applegate Peak (unit aa; 240 ka near here).

Continue southwest on East Rim Drive. 2.1

29.2 Watch for decimeter-scale columns in low andesite outcrop on right as road turns from west-northwest to north-northwest near coordinates lat $42.9110^{\circ} \mathrm{N}$., long $122.0659^{\circ} \mathrm{W}$. The columns suggest that this flow encountered ice (MIS 7.4 or 8). $\mathbf{0 . 4}$

29.6 Kerr Notch. View of caldera from overlook. Turn left (lat $42.9130^{\circ}$ N., long $122.0719^{\circ}$ W.) on Pinnacles Road to The Pinnacles. 4.8

34.4 Small unpaved turnout on left (lat $42.8636^{\circ} \mathrm{N}$., long $122.0186^{\circ} \mathrm{W}$.) provides good view into Sand Creek where ring-vent-phase ignimbrite is columnar jointed due to incipient welding and (or) vapor-phase crystallization. Such jointing is common in narrow canyons in medial ignimbrite (for example, Castle Creek and lower Annie Creek). Light gray color of columnar jointed tuff indicates relatively high emplacement temperature of mixed and mafic ignimbrite. Rhyodacite pumice in these occurrences is flattened and purplish gray. Symmetrical flat-topped peak on skyline to south is Maklaks Crater, a basaltic andesite cinder cone (unit bmc; $220 \pm 67 \mathrm{ka}$ ).

Continue on road to Pinnacles. 1.3

35.7 Stop 17. The Pinnacles (lat $42.8501^{\circ}$ N., long $122.0073^{\circ}$ W.). Vapor-phase crystallization adjacent to gas-escape pipes and sheets within medial-facies ignimbrite have made The Pinnacles resistant to erosion. Note lithic concentrations and intense fumarolic alteration within the gas-escape pipes. The best view of this oft-photographed scene on
Figure 34. View to the north of Pumice Castle, the orange outcrop in the center of the photo, from overlook on East Rim Drive. Light-colored bedded pumice at right is the same Plinian fall deposit (unit dcp). Darker layers are incipiently to densely welded, more intensely so to left, closer to vent. Cliff above pumice is dacite of Pumice Castle lava (unit dc; $71 \pm 5 \mathrm{ka}$ ), which compressed and fused underlying pumice, and is overlain by climactic pumice fall (unit $\mathrm{cp}$ ), proximal ignimbrite (unit $\mathrm{cb}$ ), and a wind-reworked pumice-rich deposit (restricted to caldera rim; included in unit cu). Skyline cliff at left is the Redcloud Cliff flow. Photograph and unit identifiers from Bacon (2008). Compare with figure 6.
Wheeler Creek, a tributary of Sand Creek, is obtained from the west end of the exposure (fig. 35), where a safe descent can be made on the tree-covered slope. Buff silicic and mixed ignimbrite form the lower part of the exposure and gray mixed and mafic ignimbrite the upper (Druitt and Bacon, 1986). The color change is consistent with increasing emplacement temperature and crystal content of the matrix upward. Andesitic

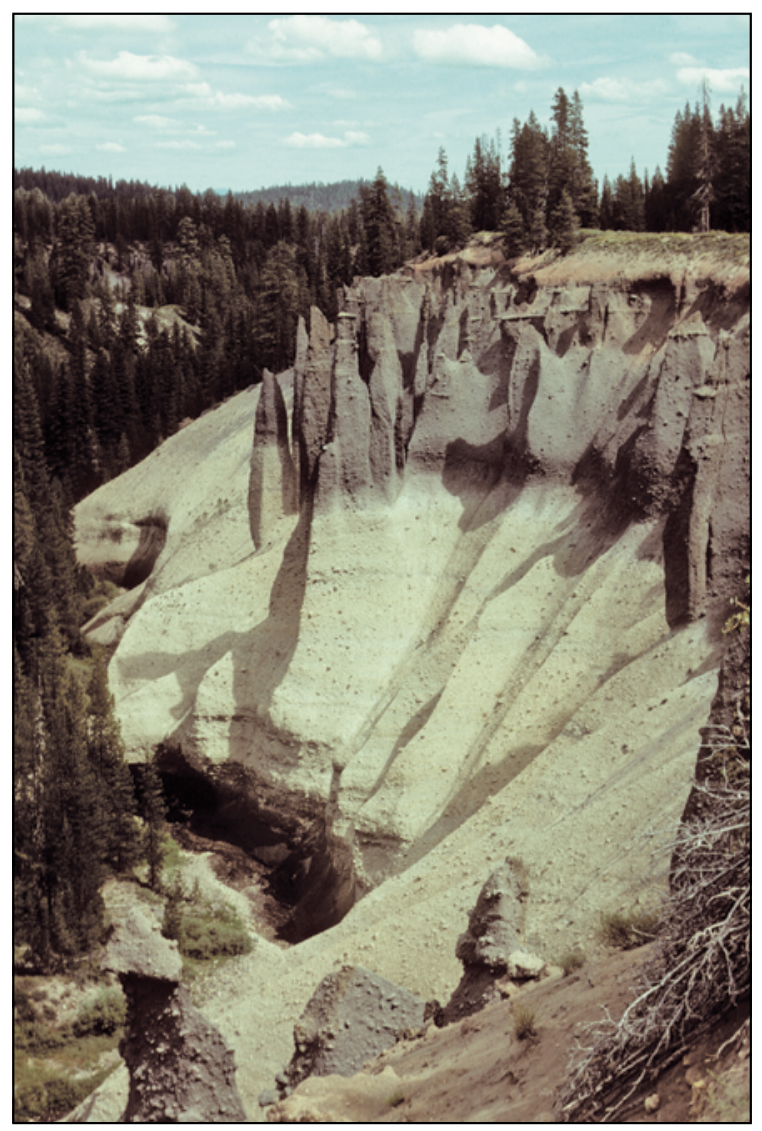

Figure 35. View to the east showing The Pinnacles on Wheeler Creek from west end of main exposure. 
scoria is common in the upper part of the buff zone and rare near its base. The base of the ignimbrite is not exposed, although the stream likely has cut down to that level. Meter-scale stratification does not correspond to sharp grain-size breaks. Note red oxidized top of the sheet and fine ash-cloud deposit. Wavy ledges near top are not primary depositional features. This locality is spectacular, particularly in late afternoon light, but is atypical of medial-facies ignimbrite in its sharp color change and stratified appearance. Compare with Stop 1 or the upper part of Castle Creek. Hills to northeast and east are mostly pre-Mazama rhyodacite of Scott Creek (unit rsc; probably 460-410 ka).

Return to East Rim Drive. 5.9

41.6 Turn left to head south on East Rim Drive (lat $42.9130^{\circ}$ N., long $122.0719^{\circ}$ W.). Note lithic breccia on right in Kerr Notch. Lava exposures in roadcuts past here are andesite of Kerr Notch (unit ak) overlain by andesite of Applegate Peak (unit aa) where springs emerge at the columnar base of a thick lava flow. 1.9

43.5 View (lat $42.8901^{\circ}$ N., long $122.0723^{\circ} \mathrm{W}$.) to south of Klamath graben, Upper Klamath Lake (30 mi; 48 km), and Medicine Lake volcano (100 mi; $160 \mathrm{~km})$, the broad shield-like form beyond Upper Klamath Lake. Snowcapped Mount Shasta $(110 \mathrm{mi} ; 177 \mathrm{~km})$ may be visible. 1.4

44.9 View (lat $42.8930^{\circ}$ N., long $122.0899^{\circ}$ W.) northwest to Applegate Peak. Silicic andesite and low-silica dacite flows (andesite of Applegate Peak, unit aa; 270-210 ka) grade from agglutinated lava upward into bomb beds in each flow unit at the caldera rim and south down the flank of Mount Mazama into streaky lava flows with rubbly tops. Lowest two to three flows are andesite of Kerr Notch (unit ak; $307 \pm 12$ ka here). Lavas in roadcuts here on East Rim Drive are strongly flow-banded olivine-bearing silicic andesites of Applegate Peak (unit aa) except the last roadcut before Sun Notch, which exposes altered andesite of Kerr Notch (unit ak). Cinder cone $\sim 2.5 \mathrm{mi}(4 \mathrm{~km})$ to south-southwest is Crater Peak, andesite lava (unit acr) from which is dated at $\sim 130-100$ ka.

45.5 Stop 18. Sun Notch. A short walk from the parking area (lat $42.8999^{\circ}$ N., long $122.0954^{\circ} \mathrm{W}$.) to the caldera rim yields a fine view of Phantom Ship (fig. 36) and Dutton Cliff from near the east end of Sun Notch. Phantom Ship is composed of parts of two hydrothermally altered flows of andesite of Phantom Cone lava; bathymetry indicates a vertical dike supports the submerged buttress northwest of the island (Bacon and others, 2002), which separates the landslide scallops of Chaski and Danger Bays, but we have not confirmed the presence of a dike in Phantom Ship itself. The near vertical upper half of the caldera wall at Dutton Cliff is composed of andesite of Applegate Peak (unit aa) that rests on a few flows of andesite of Kerr Notch (unit ak) above talus that covers bedrock to the lakeshore. At the point adjacent to Phantom Ship, lava and fragmental deposits of andesite of Phantom Cone (unit apn; 400 ka) dip away from the intrusive core (unit apni, Bacon, 2008) of the cone, which is capped by a thin flow of dacite of Phantom Cone (unit dpn). Distinctive quartz xenocrysts unique to this last unit allow it to be identified in the south wall of Kerr Valley, beneath andesite of Kerr Notch. Lava outcrops in roadcuts between Sun Notch and where East Rim Drive crosses Vidae Ridge are andesite of Kerr Notch. 1.4
Figure 36. Aerial view to the north of Phantom Ship island and unnamed point in Phantom Cone. All visible rock is lava and breccia of the andesite of Phantom Cone (unit apn; 403 \pm 12 ka here). Phantom Ship tops a buttress on the submerged caldera wall whose southwest side appears to be bounded by a northwest-southeast-trending dike (Bacon and others, 2002). Beach at point becomes much more extensive at times of low lake level and indicates that surface elevation of Crater Lake has varied within only a few meters for a considerable time (Bacon and others, 2002; Nathenson and others, 2007). Photograph from Bacon (2008).

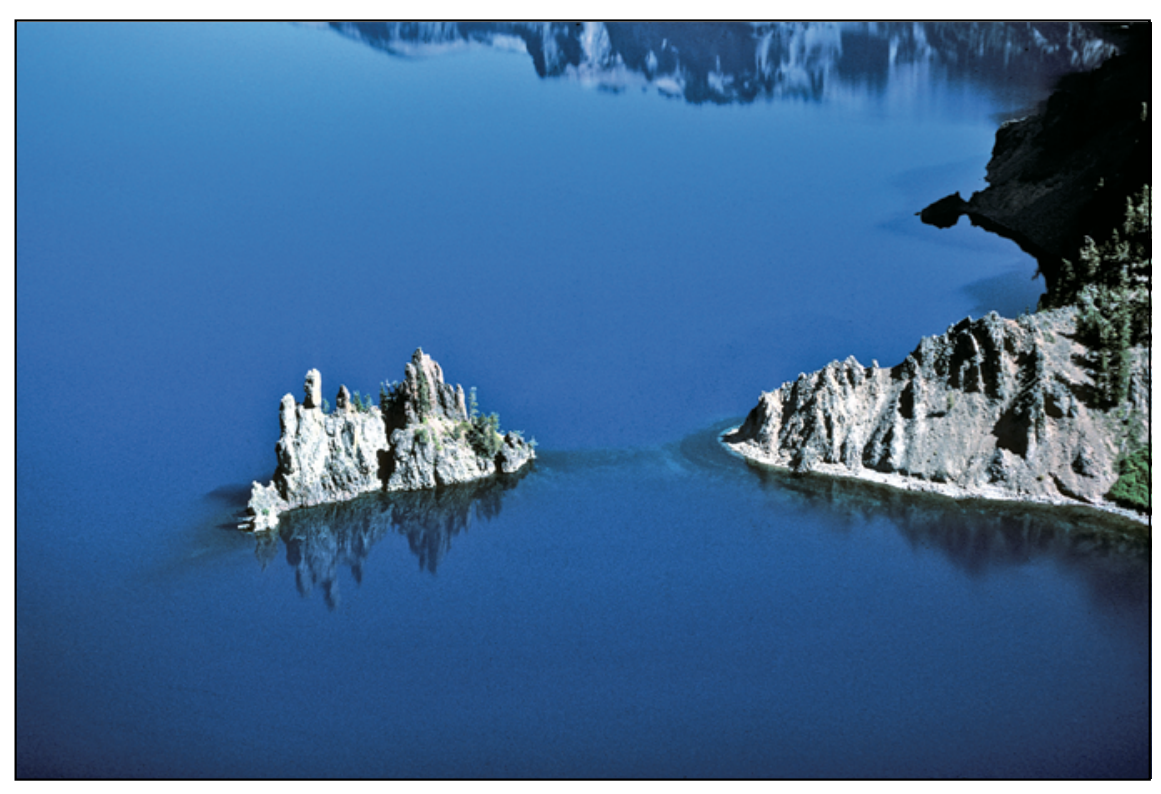


$46.9 \quad$ Vidae Falls (lat $42.8841^{\circ}$ N., long $122.0994^{\circ} \mathrm{W}$.) cascades over andesite of Kerr Notch, the stream having been encouraged in that direction by some early 20th century masonry. The side road opposite Vidae Falls leads to a picnic area with restrooms. 0.6

47.5 Columnar base and platy interior of silicic andesite lava flow well exposed in roadcut (lat $42.8770^{\circ} \mathrm{N}$., long $122.1038^{\circ} \mathrm{W}$.) where East Rim Drive bends southwest, leaves valley of Sun Creek, and crosses Vidae Ridge. 1.5

49.0 Moraine on east wall of Munson Valley (lat $42.8843^{\circ} \mathrm{N}$., long $122.1296^{\circ}$ W.). $\mathbf{0 . 9}$

49.9 Crater Lake National Park Headquarters (lat $42.8963^{\circ}$ N., long $122.1335^{\circ} \mathrm{W}$.).

End of road log.

\section{Oregon Route 138 from Roseburg to Crater Lake, Umpqua River Route}

0.0 From Roseburg take Exit 124 east from Interstate 5 to O.R. 138 (NE Diamond Lake Blvd; lat 43.2134 N., long $123.3432^{\circ} \mathrm{W}$.). Mileages are east from mile 0.0 at intersection of O.R. 138 and U.S. Highway No. 99 (U.S. 99; SE Stephens Street). The highway follows the North Umpqua River, passing exposures of Eocene basalt of the accreted Siletz terrane for $\sim 7 \mathrm{mi}(11 \mathrm{~km})$, then across poorly exposed east-dipping Eocene Umpqua Group sedimentary rocks. $\mathbf{1 6 . 2}$

16.2 Confluence of the North Umpqua and Little Rivers at Colliding Rivers Park, where a basaltic sill in the
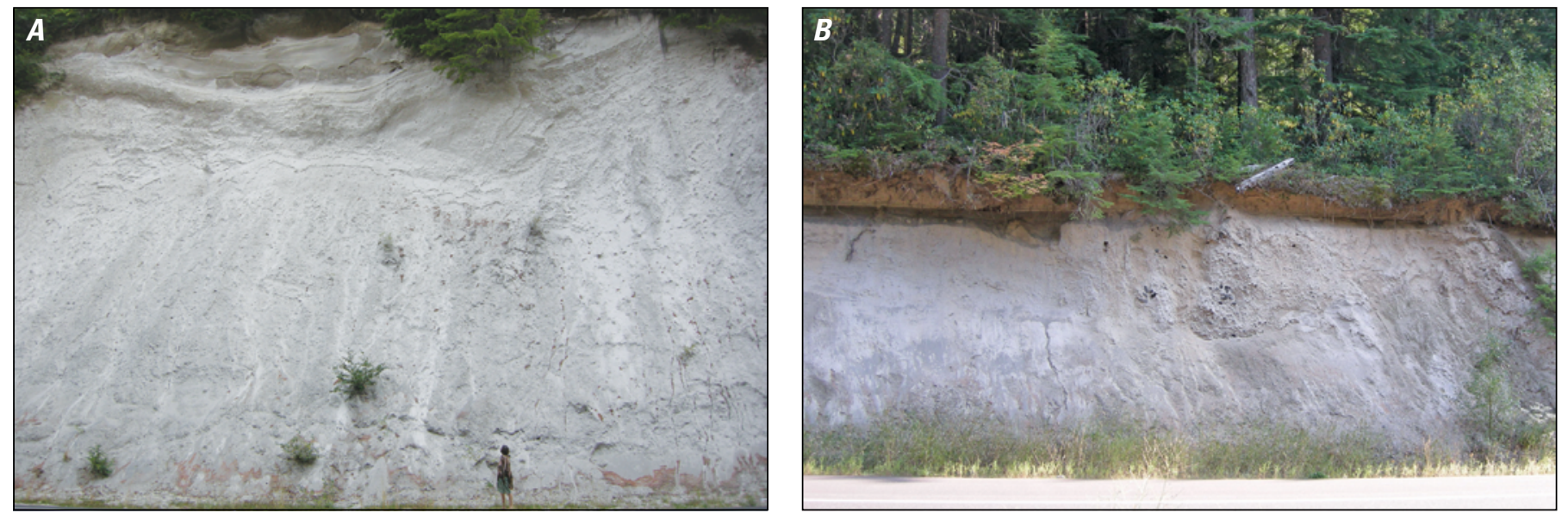

Umpqua Group forces the streams to meet nearly headon. 0.4

16.6 Past the town of Glide the highway traverses EocenePliocene Western Cascades rocks of the Little Butte Volcanics. 36.4

$\sim 53$ Mazama ignimbrite exposures begin, more than $40 \mathrm{mi}$ $(64 \mathrm{~km})$ from the source at Crater Lake. $\mathbf{6 . 0}$

$\sim 59$ The westernmost High Cascade rock is an $\sim 770 \mathrm{ka}$ intracanyon lava that forms a high ridge to the south (Sherrod, 1991). Now largely stripped away by the river, Mazama ignimbrite came down the Clearwater River valley and into the Umpqua River canyon cut adjacent to this lava. Basaltic andesite lava as young as $\sim 30 \mathrm{ka}$ (Sherrod, 1991) had earlier flowed into the Umpqua River canyon from Mount Bailey, a Pleistocene andesitic cone atop a basaltic andesite shield west of Diamond Lake (Barnes, 1992). 0.6

59.6 A safe place to examine the ignimbrite on the south side of the highway, with ample parking on the north side, is at lat $43.2582^{\circ} \mathrm{N}$., long $122.4147^{\circ} \mathrm{W}$. Here, more than $20 \mathrm{~m}$ of nonwelded rhyodacitic ignimbrite forms a long exposure with an explosion crater or channel near the east end (fig. 37A; beware of traffic!). This is a good place to collect Mazama pumice. $\mathbf{4 . 6}$

64.2 Another good ignimbrite exposure on the south side of the highway with safe parking on the north is at lat $43.2501^{\circ} \mathrm{N}$., long $122.3350^{\circ} \mathrm{W}$. This roadcut reveals nonwelded rhyodacitic ignimbrite containing charcoal, with $\sim 30 \mathrm{~cm}$ of dark water-laid ash in a channel at the top, all overlain by $\sim 1 \mathrm{~m}$ of pink ash (fig. 37B). $\mathbf{1 0 . 6}$

Figure 37. Photographs showing Mazama ignimbrite along Oregon Route 138. $A$, Roadcut at mile 59.6. $B$, Roadcut at mile 64.2 . 
74.8 Mazama pumice fall is present, but not well exposed, on glaciated lava in a roadcut on the northeast side of O.R. 138 - a short walk north of Cinnamon Butte lookout road (National Forest Service Road 4793 [NF 4793] runs east from O.R. 138; lat $43.2368^{\circ}$ N., long $122.1441^{\circ} \mathrm{W}$.) where there is parking space for four vehicles. Far better exposures of Mazama pumice fall can be visited in quarries near Chemult off of U.S. 97.3.7

78.5 Diamond Lake Resort and the north end of the lake can be accessed by National Forest Service Road 050 (NF 050) west from O.R. 138 at lat $43.1854^{\circ} \mathrm{N}$., long $122.1306^{\circ} \mathrm{W} . \mathbf{0 . 5}$

79.0 Diamond Lake viewpoint, reached by a short access road east from O.R. 138 (lat $43.1776^{\circ} \mathrm{N}$., long $122.1302^{\circ} \mathrm{W}$.), has ample parking, restrooms, and a view of Mounts Thielsen and Bailey (Sherrod, 1991; Barnes, 1992). Mazama pumice fall is poorly exposed in low roadcuts on the access road. Do not excavate to expose deposit.3.8

82.8 Junction of O.R. 230 and O.R. 138 (lat $43.1266^{\circ}$ N., long $122.1324^{\circ} \mathrm{W}$.). The south shore of Diamond Lake and a large picnic area with restrooms can be reached by proceeding west on O.R. 230 for $0.2 \mathrm{mi}(0.3 \mathrm{~km})$, then north on National Forest Service Road 6592 (NF 6592) at lat $43.1268^{\circ} \mathrm{N}$., long $122.1357^{\circ} \mathrm{W}$. for $0.7 \mathrm{mi}$ $(1.1 \mathrm{~km})$ to the south shore access road National Forest Service Road 4795 (NF 4795) (lat $43.1367^{\circ} \mathrm{N}$., long $122.1376^{\circ}$ W.). 2.9

85.7 Another $2.9 \mathrm{mi}(4.7 \mathrm{~km})$ south of the intersection with O.R. 230, O.R. 138 meets the north entrance road to Crater Lake National Park (lat $43.0889^{\circ}$ N., long $122.1167^{\circ} \mathrm{W}$.) and turns east for $\sim 15 \mathrm{mi}(24 \mathrm{~km})$ to reach U.S. 97 (lat $43.0807^{\circ} \mathrm{N}$., long $121.8250^{\circ} \mathrm{W}$.), the main north-south highway east of the Cascades. End of road log.

\section{Oregon Route 62 from Medford to Park Entrance Road, Rogue River Route}

0.0 The city of Medford is in the valley that separates Cretaceous and older Klamath Mountains rocks to the west from younger, Eocene to Pliocene rocks of the Western Cascades to the east. Leaving Interstate 5 at Exit 30 in Medford (mile 0.0; lat $42.3509^{\circ} \mathrm{N}$., long $122.8754^{\circ}$ W.), O.R. 62 follows the Rogue River and traverses sedimentary and volcanic rocks of the Western Cascades that dip to the east, are about $35 \mathrm{Ma}$ near Medford, and become progressively younger eastward. Just out of Medford and northwest of O.R. 62, prominent Table Rock is a remnant of a $\sim 7 \mathrm{Ma}$ andesite lava flow that came more than $30 \mathrm{mi}$ (more than $48 \mathrm{~km}$ ) down the ancestral Rogue River. 35.0
35.0 Where the highway crosses the east end of Lost Creek Reservoir (lat $43.6924^{\circ} \mathrm{N}$., long $122.6006^{\circ} \mathrm{W}$.) white exposures visible on the north shore are reworked (?) Mazama climactic ignimbrite. $\mathbf{7 . 5}$

42.5 After pursuing a roughly eastward path, O.R. 62 turns north just beyond Prospect (lat $42.7607^{\circ} \mathrm{N}$., long $122.4884^{\circ} \mathrm{W}$.) and follows the boundary between Western Cascades volcanic rocks and younger Pliocene and Pleistocene volcanic rocks of the High Cascades. The valley is floored by $\sim 1$ Ma high-alumina olivine tholeiite (HAOT) lava. 10.1

At Natural Bridge (access road lat $42.8926^{\circ} \mathrm{N}$., long $122.4545^{\circ} \mathrm{W}$.) part of the flow of the Rogue River is carried within a HAOT lava tube, overlain by Mazama ignimbrite. The Natural Bridge area (U.S. Forest Service) has interpretive displays, a footbridge over the Rogue, safe walkways along the basalt above the river, and restrooms. $\mathbf{1 . 2}$

\section{Beckie's Cafe and Union Creek Resort. $\mathbf{0 . 3}$}

54.1 Look for the HAOT basalt by the river at Farewell Bend (lat $42.9102^{\circ} \mathrm{N}$., long $122.4402^{\circ} \mathrm{W}$.). Beige or white exposures of pumice-rich climactic ignimbrite, commonly containing charcoal logs, will be seen atop the basalt in subsequent roadcuts on the right. Once turning east at the intersection of O.R. 62 and O.R. 230 (lat $42.9212^{\circ} \mathrm{N}$., long $122.4293^{\circ} \mathrm{W}$.), the geology is entirely Quaternary volcanic rocks of the High Cascades and Mount Mazama. 0.9

55.0 Intersection of O.R. 62 and O.R. 230. Turn right to continue on O.R. 62 and ascend the valley of Castle Creek, one of several deep glacial valleys radiating from Mount Mazama, on the surface of the ignimbrite, which is as much as $100 \mathrm{~m}$ thick near the park boundary. 8.2

63.2 Crater Lake National Park boundary (lat $42.9014^{\circ} \mathrm{N}$., long $122.2846^{\circ} \mathrm{W}$.). Collecting or disturbing rock or other natural specimens in Crater Lake National Park is prohibited except by special permit. 1.6

64.8 Castle Creek has cut a slot canyon through the ignimbrite where the ash matrix is gray, partly welded and vapor-phase indurated, and cracked into columns as much as $2 \mathrm{~m}$ across. Park at paved turnout on north side of highway (lat $42.8949^{\circ} \mathrm{N}$., long $122.2537^{\circ} \mathrm{W}$.) near the confluence of Castle Creek and Little Castle Creek and walk short distance back along highway for view into canyon. Ignimbrite lies on Pleistocene HAOT (basalt of Castle Creek, unit bcc) here. Postglacial HAOT (basalt of Castle Point, unit bc), the youngest regional mafic lava in the Crater Lake region, was erupted from 
either side of Castle Point $1 \mathrm{mi}(1.6 \mathrm{~km})$ south of here. The basalt is overlain by Mazama ignimbrite. Details of the remarkably well preserved surface of the ignimbrite were revealed by the 2010 lidar survey of the park (fig. 38; Robinson and others, 2017). The lidar survey also detected north-south meter-scale normal fault scarps, down to the east, on either side of the valley of

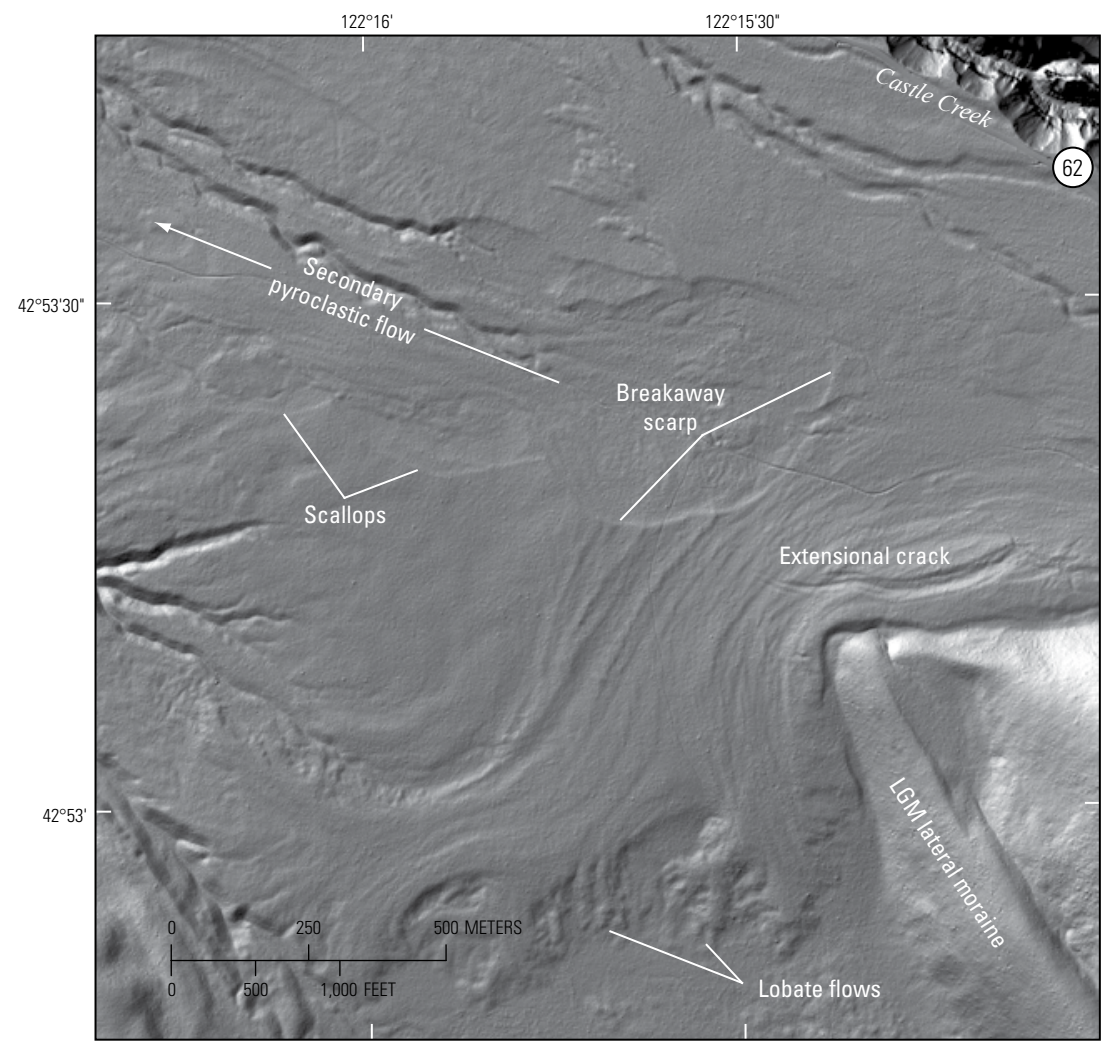

Castle Creek that displace LGM moraine and valley wall but are locally mantled or buried by climactic ignimbrite (fig. 39). 6.1

70.9 Access road to the caldera rim and park facilities (lat $42.8658^{\circ} \mathrm{N}$., long $122.1691^{\circ} \mathrm{W}$.).

End of road log.

Figure 38. Oregon Route 62 climbs out of Castle Creek valley, over High Cascades basaltic andesite lava (middle Pleistocene basaltic andesite of Whitehorse Bluff, unit bx), and descends the Annie Spring fault scarp to meet the road to the caldera rim. Image showing ground surface in the vicinity of Castle Point as revealed in shaded relief derived from airborne light detection and ranging (lidar) survey (from Robinson and others, 2016, fig. $8 A$ ). Primary morphology is preserved on mixed ignimbrite, including flow lobes. About $1 \mathrm{~km}$ southwest of the confluence of Little Castle and Castle Creeks is a 900-m-long, 1- to 2-m-high arcuate breakaway scarp that is the headwall of a source collapse that fed a secondary pyroclastic flow directed down valley.

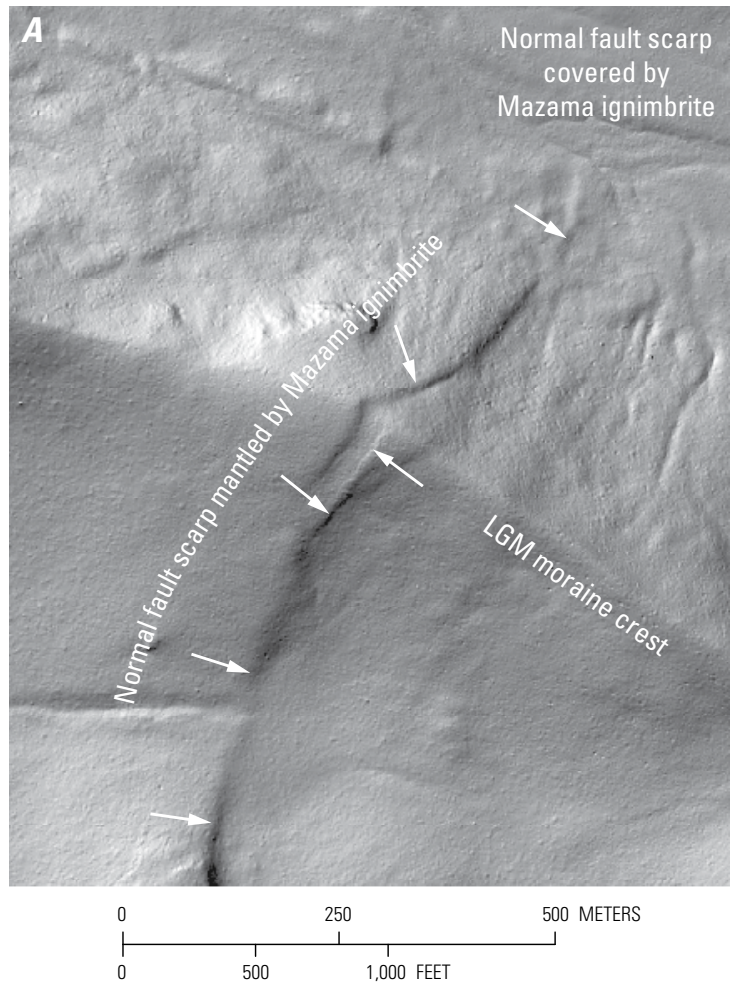

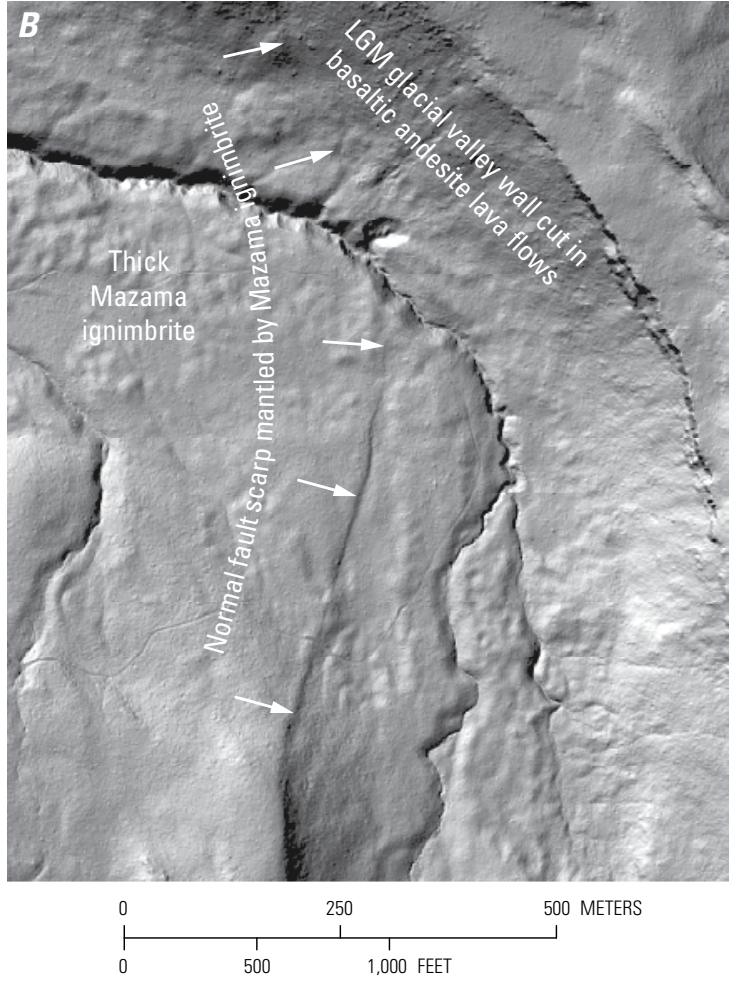

Figure 39. Airborne light detection and ranging (lidar) images showing normal fault scarps (white arrows) north and south of Castle Creek. Climactic ignimbrite banks against or locally buries scarps. Last displacement was therefore between $\sim 16$ ka ice retreat and 7.7 ka climactic eruption. $A$, Scarp displaces Last Glacial Maximum (LGM) moraine north of Castle Creek. B, Scarp cuts the glacial valley wall north of Union Peak. 


\section{Oregon Route 230 Between Oregon Routes 62 and 138, Rogue River to Diamond Lake}

0.0 Begin log at intersection of O.R. 62 and O.R. 230 (lat $42.9212^{\circ}$ N., long $122.4293^{\circ}$ W.). O.R. 230 follows the Rogue River on its east side for $\sim 5 \mathrm{mi}(8 \mathrm{~km})$, passing roadcuts in Mazama ignimbrite on $\sim 1 \mathrm{Ma}$ HAOT and then riding on the ignimbrite surface before descending to cross the Rogue. This part of the Rogue flows along the boundary, presumably a normal fault zone, between Quaternary High Cascades lavas on the east and Tertiary rocks of the Western Cascades on the west. 4.4

4.4 For a good view of the full thickness of ignimbrite (nonwelded and entirely rhyodacite at this location) park on the west side of O.R. 230 at lat $42.9780^{\circ}$ N., long $122.3982^{\circ} \mathrm{W}$. and walk north a short distance to the north end of the guardrail (Do not descend toward river! Beware of traffic!). Note the roadcuts on the east side of the highway that expose fall and surge deposits of secondary steam explosions that resulted from the ignimbrite encountering the Rogue River valley. About a meter of pinkish fine ash lies at the top of the exposure. The prominent bipartite crag $\sim 3 \mathrm{mi}$ $(4.8 \mathrm{~km})$ northwest, locally known as "Rabbit Ears," is a Western Cascade plug that also is visible from the west rim of Crater Lake caldera. 18.9

23.3 Paved parking area on the south side of the road (lat $43.1255^{\circ} \mathrm{N}$., long $122.1405^{\circ} \mathrm{W}$.) offers an excellent view of Mount Thielsen $4 \mathrm{mi}(7 \mathrm{~km})$ to the east-northeast, a 300 ka shield volcano topped by glaciated composite cone (Sherrod, 1991). To the south about $10 \mathrm{mi}(16 \mathrm{~km})$ is the north rim of Crater Lake caldera. $\mathbf{0 . 3}$

23.6 To reach the south shore of Diamond Lake, where there is a large picnic area with restrooms, take NF 6592 north (lat $43.1268^{\circ}$ N., long $122.1357^{\circ}$ W.) from between the Mount Thielsen viewpoint and the O.R. 138 junction for $0.7 \mathrm{mi}(1.1 \mathrm{~km})$ to the access road NF 4795 at lat $43.1367^{\circ}$ N., long $122.1376^{\circ}$ W. 0.2

23.8 Road $\log$ ends at the intersection with O.R. 138 (lat $43.1266^{\circ}$ N., long $122.1324^{\circ} \mathrm{W}$.).

End of road log.

\section{Oregon Route 62 from U.S. Highway No. 97 to Park Entrance Road, Klamath Basin Route}

This route is the approach to Crater Lake from Klamath Falls. U.S. 97 follows impressive normal fault scarps in late Miocene-Pliocene basaltic lavas along the east side of the
Klamath graben (Sherrod and Pickthorn, 1992). Normal faults that bound the graben on the west, which compose the West Klamath Lake fault zone, are draped by High Cascades lavas. Although the High Cascades lavas are displaced by fault movement, scarps are less dramatic than on the east side of the graben where rocks are older.

0.0 Turn northwest from U.S. 97 onto O.R. 62 (lat $42.5289^{\circ}$ N., long $121.8859^{\circ}$ W.) $\sim 23 \mathrm{mi}(37 \mathrm{~km})$ north of Klamath Falls. 7.6

7.6 On the east side of the highway $\left(12.2 \mathrm{~km}\right.$; lat $42.6343^{\circ} \mathrm{N}$., long $121.9379^{\circ}$ W.) a quarry exposes Pliocene basaltic near-vent spatter and scoria, along with a feeder dike, in the normal fault scarp. 6.1

13.7 Lodging and, possibly, limited food service are available at Fort Klamath. For the next $\sim 3 \mathrm{mi}(5 \mathrm{~km})$ proceeding north from Fort Klamath and turning west and crossing the valley, the Cascade crest and peaks around Crater Lake caldera will be visible. 2.7

16.4 A turnout on the north side of the highway where it runs east-west offers a good view and an interpretive sign (lat $42.7339^{\circ} \mathrm{N}$., long $122.0172^{\circ} \mathrm{W}$.). Looking north, from west to east, peaks on the rim of Crater Lake caldera are The Watchman and Hillman Peak, Garfield Peak, Applegate Peak, and Dutton Cliff, and all $\sim 8,100 \mathrm{ft}$ $(2,470 \mathrm{~m})$ elevation; Mount Scott is the high point at $8,929 \mathrm{ft}(2,722 \mathrm{~m}), \sim 2 \mathrm{mi}(3 \mathrm{~km})$ east of the rim. Crater Peak is an andesitic cinder cone in the foreground of the caldera rim peaks. Note that the elevation here $(4,237 \mathrm{ft}$; $1,291 \mathrm{~m}$ ) at the turnout is virtually the same as the deepest part of the floor of Crater Lake!

Crossing the valley, turning northwest, then northnorthwest, O.R. 62 travels on reworked ejecta of the Mazama climactic eruption. 3.1

19.5 Clasts from the ignimbrite can be collected in a shallow quarry just south of the park boundary, which can be reached at the north edge of a restroom-equipped parking area on National Forest Service Road 6237 (NF 6237) immediately northeast of O.R. 62 (intersection lat $42.7606^{\circ} \mathrm{N}$., long $122.0593^{\circ}$ W.). 0.6

20.1 South boundary of Crater Lake National Park (lat $42.7687^{\circ} \mathrm{N}$., long $122.0620^{\circ} \mathrm{W}$.), near where O.R. 62 turns north and climbs the gentle slope on top of the ring-vent-phase ignimbrite. Collecting or disturbing rock or other natural specimens in Crater Lake National Park is prohibited except by special permit.

Between the park boundary and Stop 1 of the main road $\log (28.7 \mathrm{mi}, 46.2 \mathrm{~km})$, note roadcuts in the 
top of the ignimbrite. Lidar survey shows complex surface morphology of ignimbrite beneath forest cover (Robinson and others, 2017). Turnouts allow views into the precipitous canyon walls of Annie Creek that are cut into partly welded and vapor-phase indurated columnarjointed ignimbrite. The high bluffs to the east are pre-Mazama rhyodacite lava south of Crater Peak (unit rcs; $\sim 450 \mathrm{ka}$ ), the western limit of an expansive field of domes and lava flows (Nakada and others, 1994). Crater Peak andesitic cinder cone (unit acr, 130-100 ka) stands above the rhyodacite, east of Annie Creek and south of the flank of Mount Mazama. High Cascade basaltic andesite and andesite are west of the road, largely obscured by forest (basaltic andesite of Scoria Cone, unit bsc, $53 \pm 4 \mathrm{ka}$ is the most prominent). The West Klamath Lake fault zone continues from north of Klamath Falls along the west side of the valley of Annie Creek nearly to The Watchman on the caldera rim. Offset moraines and dated lava flows give an $\sim 300$ k.y. record of displacement that indicates a long term vertical slip rate of $\sim 0.3 \mathrm{~mm} \mathrm{yr}^{-1}$ (Bacon and others, 1999). 9.6
29.7 Main road log starts at junction with road to Crater Lake (lat $42.8658^{\circ} \mathrm{N}$., long $122.1691^{\circ} \mathrm{W}$.).

\section{Pumice Fall and Ignimbrite Near U.S. Highway No. 97 South of Chemult}

Excellent exposures of Mazama distal rhyodacitic ignimbrite lying on climactic pumice fall often are accessible either in the Chemult disposal site or in commercial quarries a short distance west of U.S. $97 \sim 0.5 \mathrm{mi}(0.8 \mathrm{~km})$ south of the town of Chemult. The road to these exposures leaves U.S. 97 (lat $43.2038^{\circ} \mathrm{N}$., long $121.7793^{\circ} \mathrm{W}$.) $8.8 \mathrm{mi}(14.2 \mathrm{~km})$ north of the intersection of O.R. 97 and O.R. 138. The photo in fig. 40 was taken in June 2014 in the South Chemult Pumice quarry (lat $43.1519^{\circ} \mathrm{N}$., long $121.7555^{\circ} \mathrm{W}$.), which is reached $\sim 2.5 \mathrm{mi}$ east of U.S. 97 by way of a gravel road (NF 86) that leaves U.S. $97 \sim 5.3$ mi north of the intersection of O.R. 97 and O.R. 138 (lat $43.1537^{\circ} \mathrm{N}$., long $121.7948^{\circ} \mathrm{W}$.). Access to exposures will vary with operations. Obtain permission from commercial operators to visit any of the quarries.

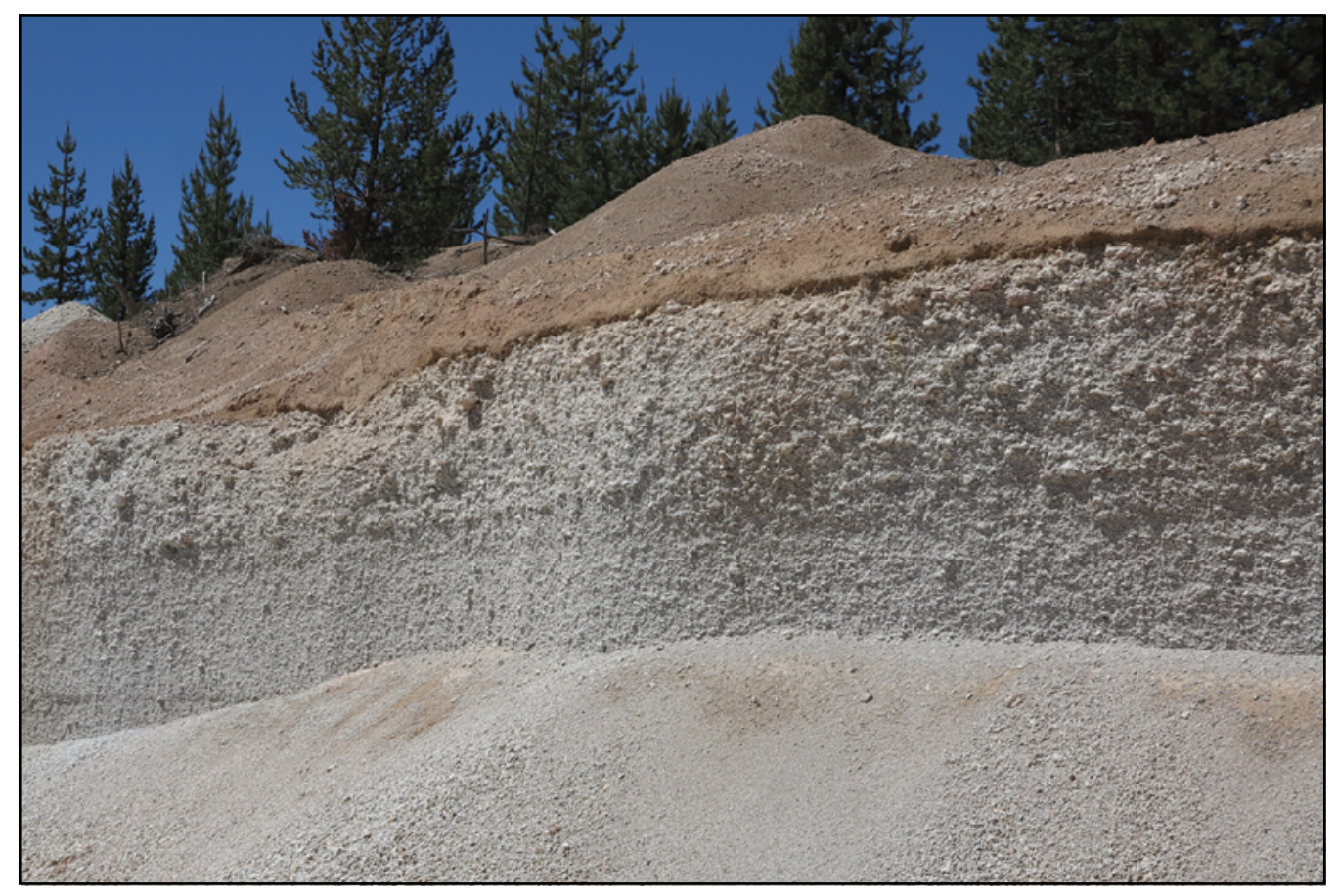

Figure 40. Photograph showing exposure of climactic pumice fall overlain by distal ignimbrite (oxidized) in South Chemult Pumice quarry. Photo by L.G. Mastin. 


\section{References Cited}

Ankney, M.E., Shirey, S.B., Hart, G.L., Bacon, C.R., and Johnson, C.M., 2016, Os and U-Th isotope signatures of arc magmatism near Mount Mazama, Crater Lake, Oregon: Earth and Planetary Science Letters, v. 437, p. 25-34.

Ankney, M.E., Bacon, C.R., Valley, J.W., Beard, B.L., and Johnson, C.M., 2017, Oxygen and U-Th isotopes and the timescales of hydrothermal exchange and melting in granitoid wall rocks at Mount Mazama, Crater Lake, Oregon: Geochimica et Cosmochimica Acta, http://dx.doi. org/10.1016/j.gca.2017.04.043.

Atwood, W.W., Jr., 1935, The glacial history of an extinct volcano, Crater Lake National Park: Journal of Geology, v. 43 , p. $142-168$.

Bacon, C.R., 1983, Eruptive history of Mount Mazama and Crater Lake caldera, Cascade Range, U.S.A.: Journal of Volcanology and Geothermal Research, v. 18, p. 57-115.

Bacon, C.R., 1985, Implications of silicic vent patterns for the presence of large crustal magma chambers: Journal of Geophysical Research, v. 90, p. 11243-11252.

Bacon, C.R., 1986, Magmatic inclusions in silicic and intermediate volcanic rocks: Journal of Geophysical Research, v. 91, p. 6091-6112.

Bacon, C.R., 1987, Mount Mazama and Crater Lake caldera, Oregon: Geological Society of America Centennial Field Guide, v. 1, p. 301-306.

Bacon, C.R., 1989, Mount Mazama and Crater Lake caldera, Oregon, in Chapin, C.E., and Zidek, J., eds., Field excursions to volcanic terranes in the western United States, Volume II — Cascades and Intermountain West: New Mexico Bureau of Mines and Mineral Resources Memoir 47, p. 203-211.

Bacon, C.R., 1990, Calc-alkaline, shoshonitic, and primitive tholeiitic lavas from monogenetic volcanoes near Crater Lake, Oregon: Journal of Petrology, v. 31, p. 135-166.

Bacon, C.R., 1992, Partially melted granodiorite and related rocks ejected from Crater Lake caldera, Oregon: Transactions of the Royal Society of Edinburgh; Earth Sciences (Hutton Symposium on Granites and Related Rocks), v. 83, p. 27-47, and Geological Society of America Special Paper 272 (The Second Hutton Symposium on the origin of granites and related rocks), p. 27-47.

Bacon, C.R., 2008, Geologic map of Mount Mazama and Crater Lake Caldera, Oregon: U.S. Geological Survey Scientific Investigations Map 2832, 4 sheets, scales 1:24,000 and 1:50,000, 45 p., https://pubs.usgs.gov/sim/2832/.
Bacon, C.R., and Druitt, T.H., 1988, Compositional evolution of the zoned calcalkaline magma chamber of Mount Mazama, Crater Lake, Oregon: Contributions to Mineralogy and Petrology, v. 98, p. 224-256.

Bacon, C.R., and Lanphere, M.A., 2006, Eruptive history and geochronology of Mount Mazama and the Crater Lake region, Oregon: Geological Society of America Bulletin, v. 118, nos. 11-12, p. 1331-1359.

Bacon, C.R., and Lowenstern, J.B., 2005, Late Pleistocene granodiorite source for recycled zircon and phenocrysts in rhyodacite lava at Crater Lake, Oregon: Earth and Planetary Science Letters, v. 233, nos. 3-4, p. 277-293.

Bacon, C.R., and Nathenson, M., 1996, Geothermal resources in the Crater Lake area, Oregon: U.S. Geological Survey OpenFile Report 96-663, 34 p., https://pubs.usgs.gov/of/1996/0663/ report.pdf.

Bacon, C.R., Adami, L.H., and Lanphere, M.A., 1989, Direct evidence for the origin of low-18O silicic magmas - Quenched samples of a magma chamber's partially-fused granitoid walls: Earth and Planetary Science Letters, v. 96, p. 199-208.

Bacon, C.R., Bruggman, P.E., Christiansen, R.L., Clynne, M.A., Donnelly-Nolan, J.M., and Hildreth, W., 1997a, Primitive magmas at five Cascade volcanic fields-Melts from hot, heterogeneous sub-arc mantle, in Nixon, G.T., Johnston, A.D, and Martin, R.F., eds., Nature and Origin of Primitive Magmas at Subduction Zones: Canadian Mineralogist, v. 35, p. 397-423.

Bacon, C.R., Gardner, J.V., Mayer, L.A., Buktenica, M.W., Dartnell, P., Ramsey, D.W., and Robinson, J.E., 2002, Morphology, volcanism, and mass wasting in Crater Lake, Oregon: Geological Society of America Bulletin, v. 114, p. 675-692.

Bacon, C.R., Gunn, S.H., Lanphere, M.A., and Wooden, J.L., 1994, Multiple isotopic components in Quaternary volcanic rocks of the Cascade arc near Crater Lake, Oregon: Journal of Petrology, v. 35, p. 1521-1556.

Bacon, C.R., Lanphere, M.A., and Champion, D.E., 1999, Late Quaternary slip rate and seismic hazards of the West Klamath Lake fault zone near Crater Lake, Oregon Cascades: Geology, v. 27 , p. $43-46$.

Bacon, C.R., Mastin, L.G., Scott, K.M., and Nathenson, M., 1997b, Volcano and earthquake hazards in the Crater Lake region, Oregon: U.S. Geological Survey Open-File Report 97-487, 32 p., https://pubs.usgs.gov/of/1997/0487/.

Bacon, C.R., Newman, S., and Stolper, E., 1992, Water, $\mathrm{CO}_{2}$, $\mathrm{Cl}$, and $\mathrm{F}$ in melt inclusions in phenocrysts from three Holocene explosive eruptions, Crater Lake, Oregon: American Mineralogist, v. 77, p. 1021-1030. 
Barnes, C.G., 1992, Petrology of monogenetic volcanoes, Mount Bailey area, Cascade Range, Oregon: Journal of Volcanology and Geothermal Research, v. 52, p. 141-156.

Bassinot, F.C., Labeyrie, L.D., Vincent, E., Quidelleur, X., Shackleton, N.J., and Lancelot, Y., 1994, The astronomical theory of climate and the age of the Brunhes-Matuyama magnetic reversal: Earth and Planetary Science Letters, v. 126, p. 91-108.

Benson, L.V., Smoot, J.P., Kashgarian, M., Sarna-Wojcicki, A.M., and Burdett, J.W., 1997, Radiocarbon ages and environments of deposition of the Wono and Trego Hot Springs tephra layers in the Pyramid Lake subbasin, Nevada: Quaternary Research, v. 47, p. 251-260.

Bowen, D.Q., Richmond, G.M., Fullerton, D.S., Sibrava, V., Fulton, R.J., and Velichko, A.A., 1986, Correlation of Quaternary glaciations in the northern hemisphere, in Sibrava, V., Bowen, D.Q., and Richmond, G.M., eds., Quaternary glaciations in the northern hemisphere: Quaternary Science Reviews, v. 5, p. 509-510 and chart 1.

Briggs, L.J., 1962, When Mt. Mazama lost its top: National Geographic, v. 122, no. 1, p. 128-133.

Bruggman, P.E., Bacon, C.R., Aruscavage, P.J., Lerner, R.W., Schwarz, L.J., and Stewart, K.C., 1987, Chemical analyses of rocks and glass separates from Crater Lake National Park and vicinity, Oregon: U.S. Geological Survey Open-File Report, 87-57, 36 p., https://pubs.usgs.gov/of/1987/0057/report.pdf.

Bruggman, P.E., Bacon, C.R., Mee, J.S., Pribble, S.T., and Siems, D.F., 1989, Chemical analyses of volcanic rocks from monogenetic and shield volcanoes near Crater Lake, Oregon: U.S. Geological Survey Open-File Report, 89-562, 17 p., https://pubs.usgs.gov/of/1989/0562/report.pdf.

Bruggman, P.E., Bacon, C.R., Mee, J.S., Pribble, S.T., and Siems, D.F., 1993, Chemical analyses of pre-Mazama silicic volcanic rocks, inclusions, and glass separates, Crater Lake, Oregon: U.S. Geological Survey Open-File Report 93-314, 20 p., https://pubs.usgs.gov/of/1993/0314/report.pdf.

Diller, J.S., and Patton, H.B., 1902, The geology and petrography of Crater Lake National Park: U.S. Geological Survey Professional Paper 3, 167 p.

Donnelly-Nolan, J.M., 2010, Geologic map of Medicine Lake volcano, northern California: U.S. Geological Survey Scientific Investigations Map 2927, scale 1:50,000, https://pubs.usgs.gov/ $\operatorname{sim} / 2927 /$.

Donnelly-Nolan, J.M., Stovall, W.K., Ramsey, D.W., Ewert, J.W., and Jensen, R.A., 2011, Newberry Volcano_Central Oregon's Sleeping Giant: U.S. Geological Survey Fact Sheet 2011-3145, 6 p., https://pubs.usgs.gov/fs/2011/3145/.
Druitt, T.H., and Bacon, C.R., 1986, Lithic breccia and ignimbrite erupted during the collapse of Crater Lake caldera, Oregon: Journal of Volcanology and Geothermal Research, v. 29, p. 1-32.

Druitt, T.H., and Bacon, C.R., 1988, Compositional zonation and cumulus processes in the Mount Mazama magma chamber, Crater Lake, Oregon: Transactions of the Royal Society of Edinburgh; Earth Sciences, v. 79, p. 289-297.

Druitt, T.H., and Bacon, C.R., 1989, Petrology of the zoned calcalkaline magma chamber of Mount Mazama, Crater Lake, Oregon: Contributions to Mineralogy and Petrology, v. 101, p. 245-259.

Dymond, J., and Collier, R.W., 1989, Bacterial mats from Crater Lake, Oregon and their relationship to possible deeplake hydrothermal venting: Nature, v. 342, p. 673-675.

Gardner, J.V., Dartnell, P., Hellequin, L., Bacon, C.R., Mayer, L.A., Buktenica, M.W., and Stone, J.C., 2001, Bathymetry and selected perspective views of Crater Lake, Oregon: U.S. Geological Survey, Water-Resources Investigations Report 01-4046, 2 sheets, https://pubs.er.usgs.gov/publication/ wri014046.

Gill, J.B., 1981, Orogenic andesites and plate tectonics: Berlin, Springer-Verlag, 390 p.

Hallet, D.J., Hills, L.V., and Clague, J.J., 1997, New accelerator mass spectrometry radiocarbon ages for the Mazama tephra layer from Kootenay National Park, British Columbia, Canada: Canadian Journal of Earth Sciences, v. 34, p. 1202-1209.

Hildreth, W., 2007, Quaternary magmatism in the CascadesGeologic perspectives: U.S. Geological Survey Professional Paper 1744, 125 p., https://pubs.usgs.gov/pp/pp1744/.

Hildreth, W., and Lanphere, M.A., 1994, Potassium-argon geochronology of a basalt-andesite-dacite arc system-The Mount Adams volcanic field, Cascade Range of southern Washington: Geological Society of America Bulletin, v. 106, p. 1413-1429.

Hildreth, W., Fierstein, J., and Lanphere, M., 2003, Eruptive history and geochronology of the Mount Baker volcanic field, Washington: Geological Society of America Bulletin, v. 115, p. 729-764.

Jensen, R.A., Donnelly-Nolan, J.M., and Mckay, D., 2009, A field guide to Newberry Volcano, Oregon, in O'Connor, J.E., Dorsey, R.J., and Madin, I.P., eds., Volcanoes to Vineyards - Geologic Field Trips through the Dynamic Landscape of the Pacific Northwest: Geological Society of America Field Guide 15, p. 53-79, doi:10.1130/2009.fl d015(03). 
Kamata, H., Suzuki-Kamata, K., and Bacon, C.R., 1993 Deformation of the Wineglass Welded Tuff and the timing of caldera collapse at Crater Lake, Oregon: Journal of Volcanology and Geothermal Research, v. 56, p. 253-265.

Karlstrom, L., Wright, H.M., and Bacon, C.R., 2015, The effect of pressurized magma chamber growth on melt migration and pre-caldera vent locations through time at Mount Mazama, Crater Lake, Oregon: Earth and Planetary Science Letters, v. 412, p. 209-219.

Lescinsky, D.T., and Fink, J.H., 2000, Lava and ice interaction at stratovolcanoes-Use of characteristic features to determine past glacial extents and future volcanic hazards: Journal of Geophysical Research, v. 105, p. 23711-23726.

Lescinsky, D.T., and Sisson, T.W., 1998, Ridge-forming, icebounded lava flows at Mount Rainier, Washington: Geology, v. 26 , p. $351-354$.

Lipman, P.W., 1997, Subsidence of ash-flow calderasRelation to caldera size and magma-chamber geometry: Bulletin of Volcanology, v. 59, p. 198-218.

Mandeville, C.W., Webster, J.D., Tappen, C., Taylor, B.E., Timbal, A., Sasaki, A., Hauri, E., and Bacon, C.R., 2009, Stable isotope and petrologic evidence for open-system degassing during the climactic and pre-climactic eruptions of Mt. Mazama, Crater Lake, Oregon: Geochimica et Cosmochimica Acta v. 73, p. 2978-3012, doi:10.1016/j. gca.2009.01.019.

Mandler, B.E., Donnelly-Nolan, J.M., and Grove, T.L., 2014, Straddling the tholeiitic/calc-alkaline transition-The effects of modest amounts of water on magmatic differentiation at Newberry Volcano, Oregon: Contributions to Mineralogy and Petrology, v. 168:1066, 25 p., doi:10.1107/ s00410-014-1066-7.

Martinson, D.G., Pisias, N.G., Hays, J.D., Imbrie, J., Moore, T.C., Jr., and Shackleton, N.J., 1987, Age dating and the orbital theory of the Ice Ages-Development of a highresolution 0 to 300,000-year chronostratigraphy: Quaternary Research, v. 27, p. 1-29.

Mathews, W.H., 1947, "Tuyas," flat-topped volcanoes in northern British Columbia: American Journal of Science, v. 245 , p. $560-570$.

McCroy, P.A., Blair, J.L., Waldhauser, F., and Oppenheimer, D.H., 2012, Juan de Fuca slab geometry and its relation to Wadati-Benioff zone seismicity: Journal of Geophysical Research, v. 117, B09306, 23 p., doi:10.1029/2012JB009407.

Miller, M.B., 2014, Roadside geology of Oregon: Missoula, Montana, Mountain Press, 386 p.
Muffler, L.J.P., Bacon, C.R., Christiansen, R.L., Clynne, M.A., Donnelly-Nolan, J.M., Miller, C.D., Sherrod, D.R., and Smith, J.G., 1989, Excursion 12B - South Cascades arc volcanism, California and southern Oregon: IAVCEI field guide, New Mexico Bureau of Mines and Mineral Resources Memoir 47, p. $183-225$.

Nakada, S., Bacon, C.R., and Gartner, A.E., 1994, Origin of phenocrysts and compositional diversity in pre-Mazama rhyodacite lavas, Crater Lake, Oregon: Journal of Petrology, v. 35 , p. $127-162$.

Nathenson, M., Bacon, C.R., and Ramsey, D.W., 2007, Subaqueous geology and a filling model for Crater Lake, Oregon: Hydrobiologia, v. 574, p. 13-27.

Nathenson, M., Clynne, M.A, and Muffler, L.J.P., 2012, Eruption probabilities for the Lassen Volcanic Center and regional volcanism, northern California, and probabilities for large explosive eruptions in the Cascade Range: U.S. Geological Survey Scientific Investigations Report 2012-5176-B, 23 p., http://pubs.usgs.gov/sir/2012/5176/b/.

Nelson, C.H., Bacon, C.R., Robinson, S.W., Adam, D.P., Bradbury, J.P., Barber, J.H., Jr., Schwartz, D., and Vagenas, G., 1994, The volcanic, sedimentologic and paleolimnologic history of the Crater Lake caldera floor, Oregon-Evidence for small caldera evolution: Geological Society of America Bulletin, v. 106, p. 684-704.

Robinson, J.E., 2012, High-resolution digital elevation dataset for Crater Lake National Park and vicinity, Oregon, based on LiDAR survey of August-September 2010 and bathymetric survey of July 2000: U.S. Geological Survey Data Series 716, https://pubs.er.usgs.gov/publication/ds716.

Robinson, J.E., Bacon, C.R., Wright, H.M., Major, J.J., and Vallance, J.W., 2017, Surface morphology of caldera-forming eruption deposits revealed by lidar mapping of Crater Lake National Park, Oregon - Implications for deposition and surface modification: Journal of Volcanology and Geothermal Research, http://dx.doi.org/10.1016/j.jvolgeores.2017.02.012.

Sisson, T.W., and Bacon, C.R., 1999, Gas-driven filter pressing in magmas: Geology, v. 27, p. 613-616.

Sherrod, D.R., 1991, Geologic map of a part of the Cascade Range between latitudes $43^{\circ}-44^{\circ}$, central Oregon: U.S. Geological Survey Miscellaneous Investigations Series Map I-1891, scale 1:125,000, pamphlet 14 p., https://pubs.er.usgs.gov/publication/ i1891.

Sherrod, D.R., and Pickthorn, L.B.G., 1992, Geologic map of the west half of the Klamath Falls $1^{\circ}$ by $2^{\circ}$ quadrangle, south-central Oregon: U.S. Geological Survey Miscellaneous Investigations Series Map I-2182, scale 1:125,000, https:/pubs. er.usgs.gov/publication/i2182. 
Smith, R.L., 1979, Ash-flow magmatism, in Chapin, C.E., and Elston, W.E., eds., Ash-flow tuffs: Geological Society of America Special Paper 180, p. 5-27.

Stuiver, M., Reimer, P.J., and Braziunas, T.F., 1998, Highprecision radiocarbon age calibration for terrestrial and marine samples: Radiocarbon, v. 40, p. 1127-1151.

Suzuki-Kamata, K., Kamata, H., and Bacon, C.R., 1993, Evolution of the caldera-forming eruption at Crater Lake, Oregon, indicated by component analysis of lithic fragments: Journal of Geophysical Research, v. 98, p. 14059-14074.

Till, C.B., Grove, T.L., Carlson, R.W., Donnelly-Nolan, J.M., Fouch, M.J., Wagner, L.S., and Hart, W.K., 2013, Depths and temperatures of asthenopheric melting and the lithosphereasthenosphere boundary in the southern Cascades arc and back-arc: Geochemistry, Geophysics, Geosystems, v. 14, no. 4, p. 864-879.

Wheat, C.G., McManus, J., Dymond, J., Collier, R., and Whiticar, M., 1998, Hydrothermal fluid circulation through the sediment of Crater Lake, Oregon-Pore water and heat flow constraints: Journal of Geophysical Research, v. 103, p. 9931-9944.
Williams, D.L., and Von Herzen, R.P., 1983, On the terrestrial heat flow and physical limnology of Crater Lake, Oregon: Journal of Geophysical Research, v. 88, p. 1094-1104.

Williams, H., 1941, Calderas and their origin: University of California Publications, Bulletin of the Department of Geological Sciences, v. 25, no. 6, p. 239-346.

Williams, H., 1942, The geology of Crater Lake National Park, Oregon: Carnegie Institution of Washington Publication 540, $162 \mathrm{p}$.

Wright, H.M., Bacon, C.R., Vazquez, J.A., and Sisson, T.W., 2012, Sixty-thousand years of magmatic volatile history before the caldera-forming eruption of Mount Mazama, Crater Lake, Oregon: Contributions to Mineralogy and Petrology, v. 164, p. 1027-1052.

Young, S.R., 1990, Physical volcanology of Holocene airfall deposits from Mt. Mazama, Crater Lake, Oregon: University of Lancaster, UK, Ph.D. thesis, 298 p.

Zdanowicz, C.M., Zielinski, G.A., and Germani, M.S., 1999, Mount Mazama eruption-Calendrical age verified and atmospheric impact assessed: Geology, v. 27, p. 621-624.
Menlo Park Publishing Service Center, California

Manuscript approved June 19, 2017

Edited by Sarah Nagorsen

Layout by Cory Hurd 
㞭

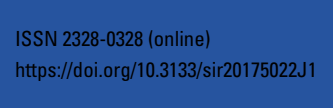

